\author{
Department of Economics \\ and \\ Institute for Policy Analysis \\ University of Toronto \\ 150 St. George Street \\ Toronto, Ontario M5S 1A1 \\ Canada \\ June 18, 1998 \\ WORKING PAPER \\ NUMBER UT-ECIPA-MUNRO5-98-03
}

The Symbiosis of Towns and Textiles: Urban Institutions and the Changing Fortunes of Cloth Manufacturing in the Low Countries and England, 1280 - 1570

by

John H. Munro

Copyright 1998 by John H. Munro

Department of Economics

University of Toronto

Author's e-mail: munro5@chass.utoronto.ca

On-line version: http://www.chass.utoronto.ca/ecipa/wpa.html 


\title{
The Symbiosis of Towns and Textiles: Urban Institutions and the Changing Fortunes of Cloth Manufacturing in the Low Countries and England, 1280 - 1570
}

\author{
John Munro \\ University of Toronto \\ $* * * * * * * * * * * * * * * * * * * * * * * * * * * * * * *$
}

\begin{abstract}
:
This paper, a contribution to the 'proto-industrialisation' debate, examines the relative advantages of urban and rural locations for cloth manufacturing in later-medieval England and the Low Countries. From the 11th to the mid-14th century, when the English cloth trade began its seemingly inexorable expansion, the Low Countries had enjoyed a virtual supremacy in international cloth markets, then chiefly located in the Mediterranean basin. The traditional view has attributed the ultimate English victory to the advantages of a rural location, using cheap labour and water-powered fulling. The proponents of this view further contend that in late thirteenth-century England a new rural industry had displaced a centuries-old 'traditional' urban cloth industry through such superior cost advantages. To challenge that view, this paper puts forth the following propositions: (1) that England's traditional urban industry had declined, abruptly from the 1290s, chiefly because of steeply rising, war-induced, transaction costs in Mediterranean markets for its chief products: i.e. cheap and light fabrics, which they had sold as price-takers; (2) that the Flemish/Brabantine cloth industries, having had a similar industrial-commercial orientation, suffered from the same industrial crisis; and it more quickly responded by reorienting production, as price-makers, to very high-priced luxury woollens; (3) that rural locations were not always more advantageous, in lower labour and other costs; (4) that urban locations offered important benefits for the luxury-cloth production: a more highly skilled, productive, better regulated labour force; urban and guild institutions to enforce necessary quality controls and promote international reputations for high quality; (5) that England's cloth industry, when it revived from the 1360s, followed suit in shifting to more luxury-oriented exports, while gaining its chief advantages from the fiscal burdens imposed on high-quality wool exports to its overseas competitors; (6) that English export-oriented cloth production also remained more urban than rural until the late fifteenth century (for many complex reasons explored in this paper).
\end{abstract}

\section{JEL Classifications: N1, N3, N4, N6, N7}




\title{
The Symbiosis of Towns and Textiles: Urban Institutions and the Changing Fortunes of Cloth Manufacturing in the Low Countries and England, 1280 - 1570
}

\author{
$* * * * * * * * * * * * * * * * * * * * * * * * * * * * * *$ \\ The proto-industrialization debate revisited: urban vs. rural locations for textile manufactures in later- \\ medieval and early-modern Europe
}

In the view of many economic historians, the industrial and commercial supremacy that the southern Low Countries had so long enjoyed in northern Europe, from the eleventh to fourteenth centuries, had been based primarily upon a strongly welded symbiosis between towns and textiles, but one that ironically contained the very seeds of this region's relative economic decline during the later fourteenth and fifteenth centuries. In most traditional concepts of that symbiosis, towns were fundamentally necessary for the expansion of this region's world-renowned cloth industries, whose exports in turn provided the most powerful dynamics for urban growth during the High Middle Ages: especially in Flanders, adjacent Artois, and then Brabant. ${ }^{1}$ If Holland's

1 Few if any towns in the Low Countries, however, owed their medieval origins directly to textiles. For urban formation and the textile industries in the southern Low Countries, see (in chronological order of original publication): Henri Pirenne, Histoire de Belgique des origines à nos jours, new illustrated edition, 4 vols. (Brussels, 1956) [1st edn., 1900, 5th edn. 1928], i, pp. 121-37, 169-81, 225-56; Georges Espinas, La vie urbaine à Douai au moyen âge, 4 vols. (Paris, 1913); Henri Pirenne, Belgian Democracy (London, 1915), reissued as Early Democracies in the Low Countries: Urban Society and Political Conflict in the Middle Ages and Renaissance (New York, 1963), pp. 76-155; Georges Espinas, La draperie dans la Flandre française au moyen âge, 2 vols. (Paris, 1923); Florent Prims, "De eerste eeuw van de lakennijverheid te Antwerpen (1226-1328)", Antwerpsche archievenblad, 2nd ser., 3 (1928), 105-49; Henri Laurent, Un grand commerce d'exportation au moyen âge: la draperie des Pays Bas en France et dans les pays mediterranéens, XIIe - XVe siècle (Paris, 1935); Hans Van Werveke, "De ekonomische geschiedenis," in L. Van der Essen and François-L. Ganshof, eds., Geschiedenis van Vlaanderen, ii: Middeleeuwen (Amsterdam, 1937), pp. 188 267; Hans Van Werveke, Gand: Esquisse d'histoire sociale (Brussels, 1946), pp. 22-69; Renée Doehaerd, L'expansion économique belge au moyen âge (Brussels, 1946), pp. 27-78; Hans Van Werveke, "Essor et déclin de la Flandre," in Studi in onore di Gino Luzzatto, 4 vols. (Milan, 1949-50), I, pp. 152-60, reprinted in his Miscellanea Mediaevalia: Verspreide opstellen over economische en sociale geschiedenis van de middeleeuwen (Ghent, 1968), pp. 3-11; Émile Coornaert, "Draperies rurales, draperies urbaines: l'evolution de l'industrie flamande au moyen âge et au XVIe siècle", Revue belge de philologie et d'histoire, 28 (1950), 59-96; Hans Van Werveke, "Esquisse d'une histoire de la draperie: introduction historique", in Guy De Poerck, La draperie médiévale en Flandre et en Artois: technique et terminologie, 3 vols. (Bruges, 1951), I, pp. 7-25, reprinted in his Miscellanea Mediaevalia (Ghent, 1968), pp. 350-64 (with extensive bibliography); Jean Lestocquoy, Aux origines de la bourgeoisie: les villes de Flandre et d'Italie sous le gouvernement des patriciens, XIe - XVe siècles (Paris, 1952), pp. 31-130; Félicien Favresse, Études sur les métiers bruxellois au moyen âge (Brussels, 1961); Raymond Van Uytven, Stadsfinanciën en stadsekonomie te Leuven: van de XIIe tot het einde der XVIe eeuw, Verhandelingen van de Koninklijke Vlaamse Academie voor Wetenschappen, Letteren, en Schone Kunsten van België, Klasse der Letteren, Jaargang XXXiii (Brussels, 1961); Jan A. Van Houtte, "Die Städte der Niederlande im Übergang vom Mittelalter zur Neuzeit," Rheinishe Vierteljarhrsblätter, 27 (1962), 50 - 68; RobertHenri Bautier, "La place de la draperie brabançonne et plus particulièrement bruxelloise dans l'industrie textile au moyen âge", Annales de la société royale d'archéologie de Bruxelles, 51 (1966), 31-63; J. A. Van Houtte, Bruges: Essai d'histoire urbaine (Brussels, 1967), pp. 11-76; David Nicholas, "Medieval Urban Origins in Northern 
somewhat later urbanization was based more on maritime trade, brewing industries, and the herring fisheries,

woollen textiles were still vitally important for the growth of such towns as Leiden and Den Haag. ${ }^{2}$ Thus, long

Continental Europe: State of Research and Some Tentative Conclusions", Studies in Medieval and Renaissance History, old series, 6 (1969), 53-114, reprinted in David Nicholas, Trade, Urbanisation and the Family: Studies in the History of Medieval Flanders, Variorum Collected Studies Series CS531 (Aldershot and Brookfield, Vt: Ashgate Publishing, 1996); David N. Nicholas, Town and Countryside: Social, Economic, and Political Tensions in Fourteenth-Century Flanders, Rijksuniversiteit te Gent: Werken Uitgegeven door de Faculteit van de Letteren en Wijsbegeerte no. 152 (Bruges: De Tempel, 1971); David Nicholas, Stad en platteland in de middeleeuwen (Bussum, 1971); Alain Derville, "Les draperies flamandes et artesiennes vers 1250-1350", Revue du Nord, 54 (1972), 353-70; Herman Van der Wee, "Structural Changes and Specialization in the Industry of the Southern Netherlands, 1100 1660", Economic History Review, 2nd ser. 28 (1975), 203-21, reprinted in Herman Van der Wee, The Low Countries in the Early Modern World (Variorum and Cambridge University Press, 1993; David Nicholas, "Economic Reorientation and Social Change in Fourteenth-Century Flanders," Past \& Present, no. 70 (1976), pp. 3-29; reprinted in David Nicholas, Trade, Urbanisation, and the Family (1996); Jan A. Van Houtte, An Economic History of the Low Countries, 800 - 1800 (London, 1977), pp. 17-47, 77-90; Raymond Van Uytven, "La draperie brabançonne et malinoise du XIIe au XVIIe siècle: grandeur ephémère et decadence", and Charles Verlinden, "Aspects de la production, du commerce et de la consommation des draps flamands au moyen âge," both in Federigo Melis, ed., Produzione, commercio et consumo dei panno di lana (Florence, 1976), pp. 85 - 97, 99-112; Adriaan Verhulst, "An Aspect of Continuity Between Antiquity and Middle Ages: The Origin of Flemish Cities", Journal of Medieval History, 3 (1977), pp. 175-206; Raymond Van Uytven, "Het stedelijk leven, 11de - 14de eeuw: Stadsgeschiedenis in het Noorden en Zuiden", in J. A. Van Houtte, et al, eds., Algemene geschiedenis der Nederlanden, II (Haarlem, 1982), pp. 187- 253; Wim Blockmans, "Vers une société urbanisée (XIe - XVe siècles)", in Renée Doehaerd, Wim Blockmans, Hugo Soly, Els Witte, and Jan Craeybeckx, eds., Histoire de Flandre: des origines à nos jours (Brussels, 1983), pp. 43 - 103; Raymond Van Uytven, "Les origines des villes dans les anciens Pays-Bas (jusque vers 1300)," Archives et bibliothèques de Belgique, 38 (1986), pp. 13-26; Herman Van der Wee, "Industrial Dynamics and the Process of Urbanization and De-Urbanization in the Low Countries from the Late Middle Ages to the Eighteenth Century: A Synthesis", in Herman Van der Wee, ed., The Rise and Decline of Urban Industries in the Italy and the Low Countries: Late Middle Ages Early Modern Times (Leuven, 1988), pp. 307-81; David Nicholas, Medieval Flanders (London and New York, 1971), esp. pp. 21-208; Marc Boone, Geld en macht: de Gentse stadsfinanciën en de Bourgondische staatsvorming, 1384 1453, Verhandelingen der Maatschappij voor Geschiedenis en Oudheidkunde te Gent XV (Ghent, 1990); Marc Boone, "L'industrie textile à Gand au bas moyen âge, ou les resurrections successive d'une activité réputée moribonde," and Peter Stabel, "Décadence ou survie? Économies urbaines et industries textiles dans les petite villes drapières de la Flandre orientale (14e-16e s.)," in Marc Boone and Walter Prevenier, eds., La draperie ancienne des Pays Bas: débouchés et stratégies de survie (14e - 16e siècles)/Drapery Production in the late medieval Low Countries: Markets and Strategies for Survival (14th-16th Centuries), Studies in Urban Social, Economic and Political History of the Medieval and Modern Low Countries (Leuven/Appeldorn: Garant, 1993), pp. 15-61, 63-84; John Munro, Textiles, Towns, and Trade: Essays in the Economic History of Late-Medieval England and the Low Countries, Variorum Collected Studies series CS 442 (Aldershot, Hampshire; and Brookfield, Vermont: Ashgate Publishing Ltd., 1994); Peter Stabel, De kleine stad in Vlaanderen, 14de - 16de eeuwn, Verhandelingen van de Koninklijke Academie voor Wetenschappen, Letteren en Schone Kunsten van België, Klassse der Letteren Jaargang 57 (Brussels, 1995); Peter Stabel, Dwarfs among Giants: The Flemish Urban Network in the Late Middle Ages, Studies in Urban Social, Economic and Political History of the Medieval and Modern Low Countries no. 8 (Leuven-Apeldoorn: Garant, 1997); David Nicholas, The Growth of the Medieval City: From Late Antiquity to the Early Fourteenth Century (London and New York: Longman, 1997), pp. 85-299; John Munro, “The Origins of the English 'New Draperies': The Resurrection of an Old Flemish Industry, 1270 - 1570," in Negley B. Harte, ed., The New Draperies in the Low Countries and England, 1300 - 1800, Pasold Studies in Textile History no. 10 (Oxford and New York: Oxford University Press, 1997), pp. 35 - 127; and also sources cited in nn. 10-12 below.

${ }^{2}$ See Nicolaas W. Posthumus, Geschiedenis van de Leidsche lakenindustrie, 3 vols., I: De middeleeuwen (veertiende tot zestiende eeuw) (The Hague, 1908); F. Ketner, Handel en scheepvaart van 
serving as Europe's leading cloth exporters, the Low Countries collectively became the wealthiest, most densely

Amsterdam in de vijftiende eeuw (Leiden, 1946); Marian Malowist, "L'expansion économique des Hollandais dans le bassin de la Baltique aux XIVe et XVe siècles," Studia z dziejow rzemiosla w okresie kryzysu feudalizmu w Europie Zachodniej w XIV i XV wieku (Warsaw, 1954), republished in his Croissance et régression en Europe, XIVe - XVIIe siècles (Paris, 1972), pp. 91-138; Richard Unger, "Dutch Ship Design in the Fifteenth and Sixteenth Centuries", Viator, 4 (1973), pp. 387-412, ; T.S. Jansma, "L'industrie lainière des Pays Bas du Nord et specialement celle de Hollande, XIVe - XVIIe siècles", in Marco Spallanzani (ed.), Produzione, commercio, e consumo des panni di lana (Florence, 1976), pp. 51-56; H.P.H. Jansen, "Holland's Advance", Acta Historiae Neerlandicae, 10 (1978), pp. 1-19; Dick E. H. De Boer, Graaf en grafiek: sociale en economische ontwikkelingen in het middeleeuwse Noordholland tussen \pm 1345 en \pm 1415 (Leiden, 1978); Richard Unger, "The Netherlands Herring Fishery in the Late Middle Ages: The False Legend of Willem Beukelszoon of Biervliet", Viator, 9 (1978), 335 - 56; Richard Unger, "Scheepvaart in de Noordelijke Nederlanden, 1490-1580," J.A. Van Houtte, et al, eds., Nieuwe algemene geschiedenis der Nederlanden, VII (Haarlem, 1979), 1-18; republished as "Shipping in the Northern Netherlands" in Richard W. Unger, Ships and Shipping in the North Sea and Atlantic, 1400 - 1800, Variorum Collected Series CS 601 (Aldershot and Brookfield, Vt., Ashgate, 1997); Robert DuPlessis and Martha Howell, "Reconsidering the Early Modern Urban Economy: The Cases of Leiden and Lille", Past and Present, no. 94 (Feb. 1982), pp. 49-84; Martha C. Howell, Women, Production, and Patriarchy in Late-Medieval Cities (Chicago, 1986), pp. 49 - 94 (on the Leiden drapery); A.J. Hanno Brand, "Crisis, beleid en differentiatie in de laat-middeleeuwse Leidse lakkennijverheid", in J.K.S. Moes and B.M.A. De Vries (eds.), Stof uit het Leidse verleden: zeven eeuwen textielnijverheid (Leiden, 1991), pp. 52-65, 201-05 (notes); and his "Urban Policy or Personal Government: The Involvement of the Urban Elite in the Economy of Leiden at the End of the Middle Ages," in Herman Diederiks, Paul Hohenberg, and Michael Wagenaar, eds., Economic Policy in Europe Since the Late Middle Ages: The Visible Hand and the Fortune of Cities (Leicester, 1992), pp. 17-34; and Hanno Brand, "A Medieval Industry in Decline: The Leiden Drapery in the First Half of the Sixteenth Century," in Marc Boone and Walter Prevenier, eds., La draperie ancienne des Pays Bas: débouchés et stratégies de survie (14e - 16e siècles)/ Drapery Production in the late medieval Low Countries: Markets and Strategies for Survival (14th16th Centuries) (Leuven/Appeldorn: Garant, 1993), pp. 121-49; Wim Blockmans, "The Economic Expansion of Holland and Zeeland in the Fourteenth-Sixteenth Centuries," in Erik Aerts, Brigitte Henau, Paul Janssens, and Raymond Van Uytven, eds., Studia Historica Oeconomica: Liber Amicorum Herman Van der Wee (Leuven, 1993), pp. 41-58; Jan De Vries and Ad Van der Woude, Nederland 1500 - 1815: De eerste ronde van moderne economische groei (Amsterdam: Balans, 1995); republished in English translation as The First Modern Economy: Growth, Decline, and Perserverance of the Dutch Economy, 1500 - 1815 (Cambridge and New York: Cambridge University Press, 1996), pp. 235-362. 
populated, and most highly urbanized region north of the Alps, certainly by the thirteenth century. ${ }^{3}$

Many of these historians have also contended, however, that during the next century this mutually beneficial symbiosis was ruptured, so that an urban location became more and more inimical to the future of the traditional woollen draperies in both Flanders and Brabant, just as it had been almost a century earlier to the English textile industries. According to this pessimistic view, best articulated by Henri Pirenne, their sclerotic urban industries, first in England and then in the the Low Countries, increasingly lost markets to internal domestic competition from new, upstart rural draperies. For the Low Countries' urban draperies, however, the truly fatal blow came from the rapidly expanding English cloth trade, during the later fourteenth century, based upon a newly vibrant, 'free', low-cost industry that had also become almost entirely rural in structure; but many of the rural nouvelles draperies in Flanders and Brabant were far better able to weather this English competition and prosper into the sixteenth century, again primarily because of similar advantages from their low-cost rural location.

Thus Pirenne and many subsequent historians have contended that, in Flanders, the leading towns of Ghent, Bruges, and Ypres, known as the drie steden, and, in neighboring Brabant, the comparable drie steden of Brussels, Leuven, and Mechelen must themselves bear the major responsiblity for the subsequent 'decline and fall' of this region's traditional woollen cloth industry. In their view, these towns subjected their draperies to oppressive guild controls, excessive taxation, high living costs, and consequently overly expensive labour.

${ }_{3}^{3}$ According to some late-medieval censuses for the three major textile-producing provinces, the proportions of total population living in towns were: in Flanders, 36 percent of 660,700 (1469); in Brabant, 33 percent of 413,200 (1473; 39 percent in 1496); and in Holland, 45 percent of 268,200 (1514; 54 percent in the southern half). Walter Prevenier, "La démographie des villes du comté de Flandre aux XIVe et XVe siècles: État de la question: essai d'interprétation", Revue du Nord, 65 (1983), pp. 268-73; Willem Blockmans, G. Pieters, W. Prevenier, R. W. Van Schalk, "Tussen crisis en welvaart: sociale veranderingen, 1300-1500", in J.A. Van Houtte, et al, eds., Algemene geschiedenis der Nederlanden, iv: Middeleeuwen (Haarlem, 1980), pp. 42-5. See also Joseph Cuvelier, Les dénombrements de foyers en Brabant, XIVe - XVIe siècle, 2 vols. (Brussels, 1912-13), i, pp. 432-87; Joseph De Smet, "Le dénombrement des foyers en Flandre en 1469", Bulletin de la commission royale d'histoire, 99 (1935), pp. 105-150; Herman Van der Wee, The Growth of the Antwerp Market and the European Economy, Fourteenth - Sixteenth Centuries, 3 vols. (The Hague, 1963), i: Statistics, pp. 545-48. 
More specifically, the urban textile guilds, backed by the towns' judicial and police powers, are accused of engaging in a litany of sins: of restricting entry and controlling production in order to protect their members' employment and incomes; of imposing rigid industrial regulations that impeded technological innovation and stifled entrepreneurial initiative; and of fomenting dissension in political power struggles that disastrously disrupted production. The Flemish town governments and guilds were also guilty, in this general view, of impeding the industry's migration to the much freer and industrially more amenable countryside: to gain freedom from guild and urban controls; to escape high taxation; and thus to seek much lower-cost labour, with a more abundant supply of peasant craftsmen, and a lower cost of living. ${ }^{4}$ They also argue that medieval England's towns had never enjoyed the power to prevent the much earlier and more advantageous exodus of their draperies to adjacent or more distant rural locations, especially in the West Country, providing those crucial advantages that best explain how the English cloth industry managed to defeat most of its continental rivals, most especially the still urban-based draperies of the Low Countries.

Such a transition of textile manufacturing from urban to rural locations seems to have been a widespread phenomenon in late-medieval and early-modern Europe. Currently highlighting its significance is the 'Proto-Industrialization' debate, whose leading proponent for the thesis, Franklin Mendels, has contended that, in early-modern Europe, 'the rapid growth of traditionally organized but market-oriented rural industry ... induced the passage to modern industry', by serving 'as an effective dissolver of the traditional agrarian structure' and by providing 'a means of rapidly increasing industrial production'. 5 Though such interpretations may well have some merit for early-modern Europe in general, a counter-thesis can be argued for the later-

${ }^{4}$ See sources cited in nn. 1-3 above, and in n. below. Mechelen was legally a seigneurie of the Count of Flanders (from 1356), an enclave with the duchy of Brabant; but the town's economy used the Brabantine coinage and money of coinage and was effectively part of that duchy's economy.

${ }^{5}$ Franklin Mendels, "Proto-Industrialization: The First Phase of the Industrialization Process", Journal of Economic History, 32:1 (Mar. 1972), 241-61. See a critical discussion of the now vast literature on this subject in Donald C. Coleman, "Proto-Industrialization: A Concept Too Many", Economic History Review, 2nd ser. 36:3 (Aug. 1983), 435-488; L.A . Clarkson, Proto-Industrialization: The First Phase of Industrialization? (London, 1985); and Sheilagh C. Ogilvie and Markus Cerman, eds., European ProtoIndustrialization (Cambridge and New York: Cambridge University Press, 1996). 
medieval Low Countries, in defence of both towns and urban institutions: that they rescued their cloth industries from seemingly certain destruction in the fourteenth century and staved off ultimate, inevitable decline for almost a hundred years. From the mid-fifteenth century, however, their urban institutions may bear some lesser share of blame for the final and much more rapid decline of the traditional Flemish and Brabantine draperies, though this argument may be deemed moot. ${ }^{6}$

Any examination of these theses debating the relative advantages of urban and rural industrial locations must begin, however, by ascertaining why European textile industries had been so predominantly urban during the High Middle Ages, from the eleventh to early fourteenth centuries. The reason most commonly offered is relative urban security: that towns were then islands of personal freedom and economic security in a vast, often chaotic feudal, rural sea of peasant servitude. As Robert Lopez has observed, the widespread medieval urban symbol was a circle enclosing a cross, representing commercial crossroads within fully protective circular walls. $^{7}$ According to such views, many or most towns lost that relative advantage, at least for manufacturing industries, during the later Middle Ages, with the expansion and better enforcement of princely authority, the disintegration of rural seigneurialism, the diffusion of a market economy into the countryside, and a growing agricultural productivity that together liberated cheap peasant labour for industrial activities, especially in textile manufacturing under a 'putting-out' (Verlag) system. Peasant labour presumably required far lower wages than urban labour because rural living costs were generally so low, and because so many of textile artisans provided only part-time or supplemental labour, while producing their own food and working within their own homes as peasant craftsmen. ${ }^{8}$

${ }^{6}$ See below, pp.

${ }^{7}$ Robert S. Lopez, "The Crossroad Within the Wall", in Oscar Handlin and J. Burchard, eds., The Historian and the City (Cambridge, Mass., 1963), pp. 27-43; Robert Lopez, Intervista sulla città medievale, ed. Marino Berengo (Rome, 1984). p. 5. See also Paul M. Hohenberg and Lynn H. Lees, The Making of Urban Europe, 1000-1950 (Cambridge, Mass., 1985), p. 22; Nicholas, Growth of the Medieval City, pp. 85-272.

${ }^{8}$ Even in smaller Flemish towns (such as Dendermonde, Aalst), wage rates were substantially lower, as much as a third lower, than in Bruges and Ghent. Wage data extracted from construction and other accounts in the municipal treasurers' accounts in the stadsarchieven of Bruges, Ghent, Mechelen, and Leuven; and from 


\section{The Van Werveke thesis on industrial location and guild strife in Flemish textile crafts:}

For medieval Flanders, however, the late eminent Belgian historian Hans Van Werveke denied that its medieval countryside had been subject to any such feudal servitude (or, implicitly, insecurity) when cloth exports first expanded, during the later eleventh century; ${ }^{9}$ and he offered an alternative theory of the cloth industry's urban origins, one paradoxically based on mercantile illiteracy. ${ }^{10}$ According to his thesis, even though cloth production had long been a traditional household craft in peasant society, any rural industry that became market-oriented would have necessarily involved both a complex division of labour and a 'dispersal

the town accounts of Ypres, Dendermonde, Aalst in Algemeen Rijksarchief, Rekenkamer, for ca. 1350-1500. See also urban and small town wages (Brabant and Flanders) in Herman Van der Herman, The Growth of the Antwerp Market and the European Economy, Fourteenth - Sixteenth Centuries, 3 vols. (The Hague, 1963, I: Statistics, appendices 27-29, pp. 333-75; Charles Verlinden, E. Scholliers, and Jan Craeybeckx, eds., Dokumenten voor de geschiedenis van prijzen en lonen in Vlaanderen en Brabant (XVde - XVIIIde eeuw), I and II (Bruges, 1959-65); Jean-Pierre Sosson, Les travaux de la ville de Bruges, XIVe - XVe siècles: les matériaux, les hommes (Brussels, 1977), graphs 12-19, pp. 300-09; "Urban Wage Structures in LateMedieval England and the Low Countries: Work-Time and Seasonal Wages," in Ian Blanchard, ed., Labour and Leisure in Historical Perspective, Thirteenth to Twentieth Centuries, Vierteljahrschrift für Sozial- und Wirtschaftsgeschichte Beiheft series no. 116 (Stuttgart: Franz Steiner Verlag, 1994), pp. 65-78.

9 The era of Count Charles the Good (1119 - 1127) does not suggest any such rural freedom, or freedom from feudal strife: Galbert of Bruges, The Murder of Charles the Good, trans. and ed. James B. Ross, Medieval Academy Reprints (Toronto, 1982), pp. 3-75 (esp. pp. 42-51), 102-253; See also H. Van De Weerd and R. De Maeyer, Geschiedenis van Vlaanderen, i: Oudste geschiedenis (Amsterdam, 1936), pp. 211-49; François-L. Ganshof, La Flandre sous les premiers comtes (Brussels, 1949), pp. 28-57, 95-127 (for the cloth industry in this era, pp. 58-78); R.C. Van Caenegem, "Galbert of Bruges on Serfdom, Prosecution of Crime, and Constitutionalism (1127-28)," and Karen Nicholas, "The Role of Feudal Relationships in the Consolidation of Power in the Principalities of the Low Countries, 1000 - 1300", in Bernard Bachrach and David Nicholas (eds.), Law, Custom, and the Social Fabric in Medieval Europe: Essays in Honor of Bryce Lyon (Kalamazoo, Mich., 1990), pp. 89-112, 113 - 30; and as Van Caenegem observes, "serfdom was a cental theme for Galbert" (p. 94); Nicholas, Medieval Flanders, pp. 39-110 (esp. pp. 62-9); Nicholas, Growth of the Medieval City, pp. 85-168. See also the next note.

${ }^{10}$ Hans Van Werveke, "Landelijke en stedelijke nijverheid: Bijdrage tot de oudste geschiedenis van de Vlaamse steden", Verslag van de algemene vergadering der leden van het Historisch Genootschap, Utrecht (1951), pp. 37-51, reprinted in his Miscellanea Medieavalia: Verspreide opstellen over economische en sociale geschiedenis van de middeleeuwen (Ghent, 1968), pp. 365-80; Hans Van Werveke, "Industrial Growth in the Middle Ages: The Cloth Industry in Flanders", Economic History Review, 2nd ser., 6 (1954), 237-45, reprinted in his Miscellanea Mediaevalia: Verspreide opstellen over economische en sociale geschiedenis van de middeleeuwen (Ghent, 1968) (Ghent, 1968), pp. 381-90. See especially pp. 240-41 (384-85), n. 2.: "it is impossible to explain why the Flemish cloth industry of the Middle Ages was an urban one by the fact that the rural population was too much integrated in the domanial organization," citing evidence for "economically independent" building craftsmen in the countryside. 
of capital along the several stages of production', widely scattered across the countryside, and separated from urban commerce and finance. That complex structure in turn would have required extensive record and bookkeeping: a competence in written accounts and 'a developed commercial technique' that 'was not yet in existence in the eleventh century'. Consequently, the largely illiterate merchant-drapers of this era established cloth production within towns in order to to congregate their textile workers in more centralized workplaces, providing direct supervision and control, without intermediaries, and with immediate access to required commercial facilities. Not until 1179 did Flemish merchants (first in Ghent) begin to enjoy the benefits of an institutional secular education. ${ }^{11}$ Thus, according to this intriguing thesis, only after the merchant-drapers had became fully literate and numerate would they consider seeking freer and cheaper industrial locations in the countryside, and only after other, more drastic, incentives had overcome a natural inertia or reluctance to relocate their cloth production.

As attractive as this thesis may initially appear to be, it does have some rather obvious weaknesses. Certainly it seems to be contradicted by the subsequent establishment or subsequent growth of other prominent export-oriented cloth industries in major West European towns, during the thirteenth and fourteenth centuries: those in neighbouring Brabant, Holland, Normandy, and especially Italy, when and where their mercantile and industrial entrepreneurs had long been fully literate and numerate. ${ }^{12}$ Even for the much earlier Flemish and

${ }_{11}$ Van Werveke, "Stedelijke nijverheid", p. 376; Van Werveke, "Cloth Industry", p. 244-5 (389-90); Henri Pirenne, "L'instruction des marchands au moyen âge", Annales d'histoire économique et sociale, 1 (1929), reprinted in Histoire économique de l'occident médiéval, ed. Emile Coornaert (Bruges, 1951), pp. 55174.

12 For Brabant (and the enclave-seigneurie of Mechelen) and Holland, see sources cited in nn. 2-3 above. For Normandy, see Michel Mollat, "La draperie normande", in Marco Spallanzani, ed., ed., Produzione, commercio, e consumo dei panni di lana nei secoli XII-XVII (Florence, 1976), pp. 403 - 21. For Florence and other Italian industrial towns, see Alfred Doren, Studien aus der Florentiner Wirtschaftsgeschichte, i: Die Florentiner Wollentuchindustrie (Stuttgart, 1901); Hidetoshi Hoshino, L'arte della lana in Firenze nel basso medioevo: il commercio della lana e il mercato dei panni fiorentini nei secoli $X I I I-X V$, Biblioteca storica toscana a cura della deputazione toscana di storia patria no. 21 (Florence, 1980); Hidetoshi Hoshino, "The Rise of the Florentine Woollen Industry in the Fourteenth Century", in N.B. Harte and K.G. Ponting, eds., Cloth and Clothing in Medieval Europe: Essays in Memory of Professor E.M. CarusWilson (London, 1983), pp. 183 - 204; E.M. Carus-Wilson, "The Woollen Industry", in M. M. Postan and Edward Miller (eds.), Cambridge Economic History of Europe, ii: Trade and Industry in the Middle Ages, 
Artesian cloth industries, of the eleventh and twelfth centuries, the applicability of Van Werveke's literacy thesis seems rather doubtful. Evidently such towns provided these industries with other and much more important advantages: namely, marketing and financial facilities, and others to be seen later in this study. ${ }^{13}$

Nevertheless, the rest of the Van Werveke thesis, a rather more complex one than the foregoing would suggest, is important in illustrating the severe internal conflicts that beset the Flemish urban cloth industry from the later thirteenth century, and thus in more effectively illustrating the essence of the anti-urban case. In Van Werveke's view, the differential between urban and rural costs of living and thus of wages did not prove to be a serious problem so long as the Flemish-Artesian urban cloth industry had lacked foreign competition. But from the 1260s, when such competition first emerged, in the neighbouring Brabantine towns, some Flemish merchant-drapers, now fortified with a modicum of literacy, sought to reduce costs by subcontracting production to rural workers. Not surprisingly, the quasi-guilds (ambachten) of textile craftsmen in the major Flemish towns strenuously opposed such rural production that threatened their own livelihoods. They also fiercely resisted the alternative policy of the merchant-draper oligarchies, who then firmly controlled the town governments: namely, urban wage regulation to reduce that cost differential and rural advantage, a policy particularly painful in an era of steadily rising living costs. ${ }^{14}$ In brief, according to this interpretation, the textile craftsmen sought aid from the Flemish count, Guy de Dampierre, who had his own political reasons for

2nd edn. (Cambridge, 1987), pp. 646-57; Franco Franceschi, Oltre il 'tumulto': I lavoratori fiorentini dell'Arte della Lana fra Tre et Quattrocento, Biblioteca di storia toscana moderna e contemporanea, Studi et documenti no. 38 (Florence: Leo S. Olschki, 1993). In coming to produce much higher-valued luxury quality woollens, the Florentine Arte della Lana superseded both the Arte di Calimala (finishing imported northern cloths) and crafts that had produced a wide range of cheap semi-worsted textiles. See below, pp. and nn.

13 See below, pp.

${ }^{14}$ See Van Werveke, "Cloth Industry", pp. 240-1 (385-86): "In the thirteenth century, there were no craft guilds which could, with strength and independence, defend the interests of the workers. It is true that, by order of the authorities, the workers had to enlist in different corporate bodies of artisans, but that did not entitle them to elect the heads of their corporations." See also Van Werveke, "Stedlijke nijverheid", pp. 375-79; Carlos Wyffels, De oorsprong der ambachten in Vlaanderen en Brabant, Verhandelingen van de koninklijke academie voor wetenschappen, letteren en schone kunsten van België, klasse der letteren, jaargang XIII, no. 13 (Brussels, 1951). For the neo-Malthusian arguments, see $\mathrm{n}$. below. 
opposing the governing urban oligarchies; and those town governments in turn appealed to the count's overlord, the French king, Philip IV. Politically complex, bitter, occasionally bloody, strife ensued from the 1270s, culminating in the famous Battle of the Golden Spurs at Kortrijk (Courtrai), in July 1302, when the count's forces and Flemish urban militias (the clauwaerts), dominated by the textile craftsmen, so surprisingly defeated the French cavalry and helped overthrew the pro-French leliaert merchant oligarchies ${ }^{15}$. In the restructured town governments of the early fourteenth century, the urban guilds gained strong aldermanic representation, while the merchants and merchant-drapers and others of the so-called poorterie, now even more gravely weakened by steadily growing foreign dominance in the textile trades, generally found themselves relegated to a minority status in the new governments. ${ }^{16}$

That urban guild victory was, however, a Pyrrhic one that served only to exacerbate labour strife within the Flemish urban cloth industry during the fourteenth century. The four textile guilds (weavers, fullers, shearers, dyers) usually had to share power in the town governments of the drie steden with other craft and

${ }^{15}$ See Henri Nowe, La bataille des épeerons d'or, Collection 'Notre Passé' (Brussels, 1945), pp. 4593; David Nicholas, Medieval Flanders, pp. 180-216. The term clauwaerts represented the count's banner, with the lion's claw; the leliaerts, the French royal fleur-de-lys.

${ }^{16}$ See Pirenne, Histoire de Belgique, i, pp. 225-56; Hans Van Werveke, "Der flandrische Eigenhandel im Mittelalter", Hansische Geschichtsblätter, 61 (1936), 7 - 24, reprinted in his Miscellanea Mediaevalia, pp. 45 - 59; François-L. Ganshof, "Staatkundige geschiedenis," in L. Van der Essen and François-L. Ganshof, Geschiedenis van Vlaanderen, II: Middeleeuwen (Amsterdam, 1937), pp. 39-62; Van Werveke, "Ekonomische geschiedenis", in Ibid., pp. 191-253; Frans Blockmans, Het Gentsche stadspatriciaat tot omstreeks 1302 (Antwerp and The Hague, 1938); G. Doudelez, "La revolution communale de 1280 à Ypres," Revue des questions historiques, 132 (March 1938), pp. 58-78; and 132 (Sept. 1938), pp. 3-25; and 133 (Jan. 1939), pp. 21-70; Paul Rogghé, "Het Gentsche stadsbestuur van 1302 tot 1345: en een en ander betreffende het Gentsche stadspatriciaat", Handelingen der maatschappij voor geschiedenis en oudheidkunde te Gent, new series, 1 (1944), 135-63; Henri Nowe, La bataille des éperons d'or, pp. 13-82; Van Werveke, Gand, pp. 3240, 48-65; Lestocquoy, Villes de Flandre, pp. 131-74; Van Werveke, "Cloth Industry", pp. 240-45 (385-91); Van Houtte, Bruges, pp. 30-38; David Nicholas, Town and Countryside: Social, Economic, and Political Tensions in Fourteenth-Century Flanders (Bruges, 1971), pp. 53-75, 173-200; Willem Blockmans, "Revolutionaire mechanismen in Vlaanderen van de 13de to de 16de eeuw," Tijdschrift voor sociale wetenschappen, 2 (1974), 123 - 40; David Nicholas, "Economic Reorganization," pp. 3-29; Blockmans, "Vers une société urbanisée," pp. 66-83; Nicholas, Metamorphosis, pp. 1-16; and especially David Nicholas, "The Governance of Fourteenth-Century Ghent: The Theory and Practice of Public Administration," in Bernard Bachrach and David Nicholas, eds., Law, Custom, and the Social Fabric in Medieval Europe: Essays in Honor of Bryce Lyon (Kalamazoo, Mich., 1990), pp. 235 - 62; Nicholas, Medieval Flanders, pp. 186-316. See also the sources cited in nn. 1-2. 
mercantile guilds, and sometimes even with mercantile and land-owning patricians of the poorterie, who together skilfully exploited growing divisions amongst the weavers and fullers, while in Ghent the shearers ('finishers') and dyers were relegated to the 'small guilds' (kleine neringe) collective. ${ }^{17}$

By this era, with the decline of the merchant-drapers, the organization of the Flemish cloth industry had fundamentally changed. Dependent on other merchants, foreign (Italian, German, English) and domestic, for wool supplies and cloth-marketing, the master-weavers had become the dominant industrial entrepreneurs: buying and putting-out the wools, organizing production, hiring combers, carders, spinners, weaving assistants -- and also fullers. Of these employees, only the fullers were guild-organized, with some power to contest the wage that the weaver-drapers sought to impose, while the professional dyers and shearers earned fees, not wages, from various clients: domestic drapers, brokers, and foreign merchants. With very narrow profit margins, the weaver-drapers, in Van Werveke's view, were caught in a worsening cost-price squeeze between chiefly foreign merchants, for both wool and cloth, during the fourteenth century: especially with sharp increases in English wool prices, and the growth of foreign competition in European cloth markets, which were now suffering ever more severe contraction, with chronic warfare, then plagues, and consequent depopulation. Thus, as he argued, many of the urban revolts and civil wars of the fourteenth century directly or indirectly involved clashes between weavers and fullers over control of urban industrial and wage legislation. ${ }^{18}$ Other urban revolts were directed against the count, for varied reasons too complex to discuss here. But all of these

17 See sources cited in nn. 1, 14-16.

${ }^{18}$ Hans Van Werveke, "De economische en sociale gevolgen van de muntpolitiek der graven van Vlaanderen (1337-1433)", Annales de la Société d'Emulation de Bruges, 74 (1931), 1-15; reprinted in his Miscellanea Mediaevalia, pp. 243-54; Van Werveke, "Ekonomische geschiedenis", pp. 231-54; Hans Van Werveke, Jacques Van Artevelde (Brussels, 1943), pp. 24-109; Hans Van Werveke, De koopman-ondernemer en de ondernemer in de Vlaamsche lakennijverheid van de middeleeuwen (Antwerp, 1946); ;Hans Van Werveke, Gand, pp. 48-65; Hans Van Werveke, "Currency Manipulation in the Middle Ages: The Case of Louis de Male, Count of Flanders", Transactions of the Royal Historical Society, 4th series, xxxi (1949), pp. 115 - 27, reprinted in his Miscellanea Mediaevalia, pp. 255 - 67; Hans Van Werveke, "Het ambachtswezen te Gent", Federation archéologique et historique de Belgique: Annales du XXXIIIe congrès (Tournai, 1951), pp. 363-37, reprinted in his Miscellanea Mediaevalia, pp. 392-96; Van Werveke, "Cloth Industry", pp. 240-45 (385-91). See also the next note. 
post-Kortrijk revolts (1319-20, 1323-28, 1337-49, 1360-61, 1379-85), manifesting the cloth towns' economic and political instability; and, frequently involving foreign military intervention, seriously disrupted production and marketing, to the obvious advantage of their foreign competitors. ${ }^{19}$ For late-medieval Flanders, certainly, this criticism that guilds posed an impediment to textile manufacturing through their habitual strife may stand. At the same time, however, it must also be admitted that urban draperies elsewhere in the Low Countries, especially in Leiden, were not free from similar if much less bloody and prolonged industrial strife, even though their textile craft-guilds did not exercise the same political powers as those in the Flemish towns. ${ }^{20}$

Obviously, with such adverse circumstances, we do find some relative shift of textile production to the

19 See Pirenne, Histoire de Belgique, I, 273-326, 349-68; Pirenne, Belgian Democracy, pp. 76-133, 142-80; Victor Fris, "Les origines de la réforme constitutionelle de Gand de 1360-1369", Annales du XXe congrès de la fédération archéologique et historique de la Belgique, 3 (1907), 421 - 59; Ganshof, "Staatkundige geschiedenis", pp. 49-99; Paul Rogghé, "De samenstelling der Gentse schepenbanken in de 2de helft der 14de eeuw: en een en ander over de Gentse poorterie", Handelingen der maatschappij voor geschiedenis en oudheidkunde te Gent, new series, 4 (1950), pp. 22 - 31; R. De Muynck, "De Gentse oorlog (1379-1385): Oorzaken en karakter", Handelingen der maatschappij van geschiedenis en Oudheidkunde te Gent, new series, 5 (1951), 305-18; Lestocquoy, Villes de Flandre, pp. 131-74; Richard Vaughan, Philip the Bold: The Formation of the Burgundian State (London, 1962), pp. 19-38; David Nicholas, Stad en platteland in de middeleeuwen, pp. 25-82; Nicholas, Metamorphosis, pp. 1-16, 135-77; David Nicholas, The Arteveldes of Ghent: The Varieties of Vendetta and the Hero in History (Ithaca, 1988), pp. 1-71, 108-88; Nicholas, "Governance," pp. 235-60; Nicholas, Medieval Flanders, pp. 259-322; Marc Boone and Hanno Brand, "Vollersproeren en collectieve actie in Gent en Leiden in de 14e en 15e eeuw," Tijdschrift voor sociale geschiedenis, 19:2 (May 1993), 168-92; John Munro, "Industrial Entrepreneurship in the Late-Medieval Low Countries: Urban Draperies, Fullers, and the Art of Survival," in Paul Klep and Eddy Van Cauwenberghe, eds., Entrepreneurship and the Transformation of the Economy (10th - 20th Centuries): Essays in Honour of Herman Van der Wee (Leuven: Leuven University Press, 1994), pp. 377-88. In Ghent, from 1323 to 1338, the weavers were excluded from a fuller-dominated regime; from 1338 to 1349 the weavers dominated a regime that included some fullers; in 1349 the weavers were again excluded but were readmitted in 1358, and then succeeded in evicting the fullers by, or shortly after, 1361. In Bruges and Ypres, however, the fullers' guilds did retain their aldermanic seats, though with minimal powers. See n. below.

${ }^{20}$ For Leiden in particular, and the frequent fullers' strikes against the merchant-draper dominated vroedschap and gerecht in the town government, see Posthumus, Leidsche lakenindustrie, i, pp. 308-47, 3627; and relevant documents in Nicolaas Posthumus, ed., Bronnen tot de geschiedenis van de leidsche textielnijverheid, 1333-1795, 6 vols. (The Hague, 1910-22), i: De middeleeuwen, Rijks geschiedenkundige publicatiën no. 8 (The Hague, 1910); Boone and Brand, "Vollersproeren," pp. 168-92; Marc Boone, Hanno Brand, and Walter Prevenier, "Revendications salariales et conjoncture économique: les salaires de foulons à Gand et à Leyde au XVe siècle," in Erik Aerts, Brigitte Henau, Paul Janssens, and Raymond Van Uytven, eds., Studia Historica Oeconomica: Liber Amicorum Herman Van der Wee (Leuven, 1993), pp. pp. 59-74; Munro, "Industrial Entrepreneurship," pp. 377-88. See also sources cited in n. 2 above. 
Flemish countryside during the fourteenth century, even though village cloth-making had already become quite substantial by the thirteenth century. ${ }^{21}$ Somewhat surprisingly, Van Werveke, understated the growth of rural clothmaking in the later-medieval Flanders, while still stressing the role of mercantile literacy in that shift. In his view, rural textiles sucessfully flourished only in south-west Flanders, where Ypres, the smallest and weakest of Flanders' drie steden, failed to enforce its ban on such rural cloth-making within its own castellany (jurisdiction) during the fourteenth and fifteenth centuries. ${ }^{22}$

That view, however, though repeated by many historians, requires some significant qualifications. ${ }^{23}$

${ }^{21}$ See Georges Espinas and Henri Pirenne, eds., Recueil de documents relatifs à l'histoire de l'industrie drapière en Flandre, Ire partie: Des origines à l'époque bourguignonne, 4 vols. (Brussels, 19061924); and Renée Doehaerd, ed., Les relations commerciales entre Gênes, la Belgique, et l'Outremont, d'après les archives notariales génoises aux XIIIe et XIVe siècles, 3 vols. (Brussels, 1941): for such Flemish villages as Dixmude, Poperinge, Hondschoote, Ghistelles, Cassel, in which export-oriented cloth production can be documented for the 12th and 13th centuries. Some of this rural production (before 1320), however, was subordinate to and controlled by the large urban draperies. See especially Émile Coornaert, Un centre industriel d'autrefois: la draperie-sayetterie d'Hondschoote, XIVe - XVIIIe siècles (Paris, 1930), pp. 1-26; Coornaert, "Draperies rurales", pp. 62-5, 69-80; Nicholas, Town and Countryside, pp. 76-116 ("Urban and Rural Textiles to 1338"); Adriaan Verhulst, "L'économie rurale de la Flandre et la dépression économique du bas moyen âge", Études rurales, 10 (1963), 68-80; Alain Derville, "Les draperies flamandes et artesiennes vers 1250-1350", Revue du Nord, 54 (1972), pp. 353-70; Van der Wee, "Structural Changes", pp. 203-21 ; Patrick Chorley, "The Cloth Exports of Flanders and Northern France During the Thirteenth Century: A Luxury Trade?" Economic History Review, 2nd ser. 40 (1987), 349-79; John Munro, "Industrial Transformations in the North-West European Textile Trades, c. 1290 - c. 1340: Economic Progress or Economic Crisis?" in Bruce M. S. Campbell, ed., Before the Black Death: Studies in the 'Crisis' of the Early Fourteenth Century (Manchester and New York, 1991), pp. 110 - 48; reprinted in John Munro, Textiles, Towns, and Trade: Essays in the Economic History of Late-Medieval England and the Low Countries (Aldershot, 1994); John Munro, "The Origins of the English 'New Draperies': The Resurrection of an Old Flemish Industry, 1270 - 1570," in Negley B. Harte, ed., The New Draperies in the Low Countries and England, 1300 - 1800, Pasold Studies in Textile History no. 10 (Oxford and New York, 1997), pp. 35 - 127.

${ }^{22}$ Van Werveke, "Cloth Industry", pp. 244-45 (pp. 389-91 in Miscellanea Medievalia).

${ }^{23}$ For the classic views, which unfortunately and incorrectly also refer to the nouvelles draperies as "draperies légères," producing supposedly cheap, light cloths, see: Henri Pirenne, "Une crise industrielle au XVI siècle: la draperie urbaine et la 'nouvelle draperie' en Flandre," Bulletins de l'Académie Royale de Belgique, Classe des Lettres (1905), reprinted in Histoire économique de l'occident médiéval, ed. Emile Coornaert (Bruges, 1951), pp. 621-43; Verlinden, "Draps flamands," pp. 85-112. For other, alternative views, see especially see Coornaert, Hondschoote, pp. 1 - 26; Coornaert, "Draperies rurales," pp. 60-96; Federigo Melis, "La diffusione nel Mediterranea occidentale dei panni di Wervicq e delle altre citta della Lys attorna al 1400", in Studi in onore di Amintore Fanfani, iii: Medioevo (Milan, 1962), pp. 219-43; Federigo Melis, "L'industrie drapière au moyen âge dans la vallée de la Lys, d'Armentières à Gand", in Hulde aan Paul Ferrant-Dalle (Wervik, 1967), pp. 151-61; Nicholas, Town and Countryside, pp. 76-116, 203-21; John Munro, "Monetary 
The drie steden were never empowered to suppress the many village or draperies, spread across Flanders, that had already obtained charters. Furthermore, the drie steden, who themselves evidently continued to rely on rural yarn production, tolerated much rural textile manufacturing, while concentrating their opposition on those village draperies that were imitating their own fine woollens. Certainly from the 1330s, the drie steden had much to fear on these very grounds from the growth of the so-called nouvelles draperies, many located in villages of south-west Flanders, but most outside the jurisdiction of the drie steden. Finally, Van Werveke's contention that, by the mid to later fifteenth century, these nouvelles draperies had 'succeeded in outstripping the old urban industry', a view that still commands widespread support, deserves much closer scrutiny, which, however, must be postponed until the end of this study. ${ }^{24}$

\section{England's Industrial 'Transformation' in Textile Manufacturing: the 'urban industrial crisis', rural-cloth making, and rural fulling mills, c. 1290-1340}

Well before that time, however, certainly by the mid-fourteenth century, a far more dangerous threat to these Flemish urban draperies had arisen across the Channel, in England, from, as noted earlier, a cloth industry that had supposedly undergone a far more complete transformation from urban to rural structures. During the later twelfth and thirteenth centuries, cloth-making had indeed been a major industrial activity in most of England's leading towns, especially along the eastern seaboard -- in York, Lincoln, Louth, Stamford, Beverly, Winchester, Oxford, Nottingham, Leicester, Gloucester, Exeter, Coventry, Norwich, and London itself; but, according to most historians, virtually all of these urban industries were suffering irredeemable

Contraction and Industrial Change in the Late-Medieval Low Countries, 1335-1500", in Nicholas Mayhew, ed., Coinage in the Low Countries (800-1500): Third Oxford Symposium on Coinage and Monetary History, British Archeological Reports, International Series, no. 54 (Oxford, 1979), pp. 110-61; John Munro, "Economic Depression and the Arts in the Fifteenth-Century Low Countries", Renaissance and Reformation, 19 (1983), pp. 235-50, reprinted in Textiles, Towns, and Trade; Munro, "Industrial Transformations in the North-West European Textile Trades, pp. 110-16; Munro, "Origins of the English 'New Draperies',' pp. 35127.

${ }^{24}$ Van Werveke, "Cloth Industry", pp. 244-45 (pp. 390-91); and the sources cited in the previous note, beginning with Pirenne, with whom this view began. I myself had supported this view in previous publications; but for a modification of those views, see $\mathrm{p}$. and $\mathrm{n}$. below. 
decay by the very early fourteenth century. ${ }^{25}$

In a renowned thesis that used to dominate the literature, the late Eleanora Carus-Wilson provided a dramatic explanation for not only this rural transformation but also for the English cloth industry's subsequently complete victory over all its foreign rivals: an 'industrial revolution of the thirteenth century' in

${ }^{25}$ For the literature of that urban industrial decline, in London, York, Lincoln, Stamford, Beverly, Winchester, Oxford, Nottingham, Leicester, Gloucester, Exeter, Coventry, and Norwich, see: William Cunningham, The Growth of English Industry and Commerce (Cambridge, 1890), i: During the Early and Middle Ages, 282-85; William J. Ashley, An Introduction to English Economic History (1893, 1st edn; 4th edn. 1906), ii: the End of the Middle Ages, pp. 193-5; Louis Salzman, English Industries of the Middle Ages, new edn. (Oxford, 1923), pp. 197-205; Ephraim Lipson, The History of the Woollen and Worsted Industries (1921), pp. 11-13; Ephraim Lipson, The Economic History of England, I: Middle Ages (London, 1937), pp. 448-56; E.M. Carus-Wilson, "An Industrial Revolution of the Thirteenth Century," Economic History Review, 1st ser. 11 (1941), 182-210, reprinted in E.M. Carus-Wilson, ed., Essays in Economic History, I (London, 1954), pp. 41-60; and also in E. M. Carus-Wilson, Medieval Merchant Venturers: Collected Studies (London: Methuen, 1954), pp. 183-210; E.M. Carus-Wilson, "The English Cloth Industry in the Twelfth and Thirteenth Centuries," Economic History Review, 1 st ser. 14 (1944), reprinted in Eleanora M. Carus-Wilson, Medieval Merchant Venturers, pp. 211-38; E.M. Carus-Wilson, "The Woollen Industry," in M. M. Postan and E. E. Rich, eds., Cambridge Economic History, Vol. II: Trade and Industry in the Middle Ages (Cambridge, 1952), pp. 398-29; reissued, with a few revisions in M.M. Postan and Edward Miller, eds., The Cambridge Economic History of Europe, Vol. II, 2nd rev. edn. (Cambridge, 1987), pp. 657-90; J. N. Bartlett, "The Expansion and Decline of York in the Later Midle Ages," Economic History Review, 2nd ser., 12 (1959-60), 17 - 33; A.R. Bridbury, Economic Growth: England in the Later Middle Ages (London, 1962), pp. 70-82; Herbert Heaton, The Yorkshire Woollen and Worsted Industries from the Earliest Times to the Industrial Revolution, 2nd edn. (Oxford, 1965), chapters 1-3; Edward Miller, "The Fortunes of the English Textile Industry in the Thirteenth Century," Economic History Review, 2nd ser. 18 (1965), 64-82; P.D.Z. Harvey, "The English Trade in Wool and Cloth, 1150 - 1250: Some Problems and Suggestions," in Marco Spallanzani, ed., Produzione, commercio e consumo dei panni di lana (nei secoli XXI - XVIII), Istituto internazionale di storia economica "F. Datini" Prato (Florence, 1976), pp. 369 - 76; J. L. Bolton, The Medieval English Economy, 1150-1500 (London, 1980), pp. 150-206; Andrew Woodger, "The Eclipse of the Burel Weaver: Some Technological Developments in the Thirteenth Century," Textile History, 12 (1981), 59-76; A.R. Bridbury, Medieval English Clothmaking: An Economic Survey (London,1982), pp. 27-36; Patrick Chorley, "English Cloth Exports During the Thirteenth and Early Fourteenth Centuries: the Continental Evidence," Historical Research: The Bulletin of the Institute of Historical Research, 61:144 (February 1988), 1-10; Michael Gervers, "The Textile Industry in Essex in the Late 12th and 13th Centuries: A Study Based on Occupational Names in Charter Sources," Essex Archaeology and History: The Transactions of the Essex Society for Archaeology and History, 3rd series, 20 (1989), 34 - 73; Edward Miller and John Hatcher, Medieval England: Towns, Commerce and Crafts, 1086 - 1348 (London, 1995), pp. 93-127; Wendy Childs, "The English Export Trade in Cloth in the Fourteenth Century," in Richard Britnell and John Hatcher, eds., Progress and Problems in Medieval England: Essays in Honour of Edward Miller (Cambridge and New York, 1996), pp. 121-47; Munro, "The Origins of the English 'New Draperies', pp. 35 - 127. Bridbury disputes the thesis of general urban decline, though not evidence for post 1300 decline in some of the formerly major textile towns. 
the spread of water-powered fulling mills. ${ }^{26}$ Fulling, it must be stressed, was an absolutely essential process in producing genuine heavy-weight good quality woollens, using a combination of water, soap, fullers' earth (hydrous aluminum silicates), urine, along with high levels of pressure and heat, from pounding the woven cloth: in order to scour and cleanse it of the butter and other oils used in preparing the yarns; and to force the very short, fine, scaly-fibred wool fibres to shrink, interlock, and mat together as felted cloth. Traditionally this process, which shrank the surface area by as much as 50 percent, thus giving the cloth its great density and weight, had been achieved 'under-foot', as it were, through the arduous labour of two or three men who trampled upon the woven cloth in a vat containing this unpleasant mixture, over a period of three to five days. The water-powered mill, using two very large and heavy oaken hammers, pounding the cloth up to 40 times a minute, could achieve the same task with one man in a matter of hours. In contrast to the manufacture of true woollens, it must be noted, most of cheap, coarse, light-weight textiles -- such as worsteds, says, serges, biffes, stamforts, etc.-- underwent only very cursory fulling, chiefly scouring to cleanse the cloth, or much less extensive fulling, if the hybrid serge-type fabric was composed of short-stapled, greased, woollen wefts (and long-stapled 'dry' worsted warps). ${ }^{27}$

Undoubtedly Carus-Wilson did exaggerate the 'revolutionary' benefits of mechanized fulling, and thereby inevitably invited those attacks that have largely, though quite unjustly, succeeded in discrediting her thesis. In the first major assault, Edward Miller doubted that mechanised fulling 'could have had the large [economic] consequences attributed to it', when 'fulling then accounted for about 7-12 per cent of the cost of the main manufacturing processes'. ${ }^{28}$ Furthermore, in replying to Carus-Wilson's point that manorial lords

${ }^{26}$ Carus-Wilson, "Industrial Revolution,” pp. 183-210; Carus-Wilson, "Woollen Industry", pp. 66990. See also Paolo Malinama, "The First European Textile Machine," Textile History, 17 (1986), 115-28.

${ }^{27}$ See the previous note, and John Munro, "Textile Technology," in Joseph R. Strayer, et al., eds., The Dictionary of the Middle Ages, Vol. 11 (New York, 1988), pp. 693-711; reprinted in John Munro, Textiles, Towns, and Trade: Essays in the Economic History of Late-Medieval England and the Low Countries, (Aldershot, 1994); Munro, "Industrial Entrepreneurship," pp. 377-88.

28 Miller, "English Textile Industry," pp. 71-2; but subsequently, in Miller and Hatcher, Medieval England, p. 96, Table 2.1, he provided data to indicate that fulling and finishing together accounted for 16 
had spurred the growth of a rural and a much more mechanized industry by investing in fulling mills, Miller noted that such lords would have exploited their monopoly powers over cloth-working tenants-- powers that Carus-Wilson herself had emphasized -- by charging relatively high fees ('rents', for economists), which probably would have eliminated any cost advantage of fulling-mills. ${ }^{29}$ In an even more trenchant and convincing criticism, A.R. Bridbury contended that, during the later thirteenth and early fourteenth century, the very era of Carus-Wilson's supposed 'industrial revolution', any resort to fulling mills would likely have raised production costs, not lowered them, by substituting very expensive capital for what had become dirtcheap labor in a now densely and overpopulated country, especially in the grain-growing or mixed farming regions of the Midlands, East Anglia, and the south-east. ${ }^{30}$

Apart from A. R. Bridbury, who is loath to admit any significant advantages for rural clothmaking, few of Carus-Wilson's critics have questioned her view that the English countryside did offer the later-medieval textile industry significant advantages for all, or virtually all, of the industrial processes of clothmanufacturing, including fulling. Indeed, Miller and several other historians have argued that during the later thirteenth and early fourteenth centuries, many urban clothiers, burdened by rising industrial costs, soaring taxes, and rigid guild restrictions, deserted the traditional eastern textile towns to relocate in the countryside, as the only effective competitive response to a supposed influx of supposedly cheaper and better quality Flemish woollens. ${ }^{31}$ The primary rural locations so chosen for the 'new' English cloth industries, however,

percent of manufacturing costs at Beaulieu Abbey (1270) and 20 percent at Laleham (1294-95). See also T.H. Lloyd, "Some Costs of Cloth Manufacture in Thirteenth-Century England," Textile Industry, 1 (1968-70), 3326. These data do not indicate, however, whether the fulling was undertaken by a water-mill or by the fullers' feet.

${ }^{29}$ Cf. Carus-Wilson, "Industrial Revolution," pp. 199, 201: "the [manorial lords] insisted also that all cloth made on the manor must be brought to the manorial mill and there fulled by the new mechanical method..."

${ }^{30}$ Bridbury, Medieval English Clothmaking, pp. 16-26. He also cited the presence of fulling mills in many other areas of rural England that never became significant cloth-exporing regions.

${ }^{31}$ See Miller, "English Textile Industry," pp. 74-81; Miller and Hatcher, Medieval England, pp. 10724; see also, for similar views, Woodger, "Eclipse of the Burel Weaver," pp. 59-76; Harvey, "English Trade," 
were not those adjacent to the major textile towns of eastern lowland England (in Yorkshire, Lincolnshire, Norfolk, Leicestershire, Huntingdonshire, Northamptonshire, Oxfordshire, Middlesex), but primarily in the West Country (Devon, Somerset, Gloucestershire, Worcestershire, Wiltshire) and secondarily in East Anglia (Suffolk and Essex). That geographical shift is more or less ignored by Carus-Wilson's critics, who focus instead on the obvious, oft-proclaimed benefits of a rural location in general, veritably as a mantra : freedom from guilds, freedom from urban governments and their taxes, and low-wage and thus presumably lower-cost peasant labour. ${ }^{32}$ Such factors were not only more important than fulling mills but preceded them as well, in the sense that such mills spread only after cloth-making had already become fully established: for who would invest in a capital-costly mill without a large pre- existing clientele of local, resident cloth artisans? For Miller the true importance of rural locations lay in the carding, combing, spinning, and weaving processes, which together accounted for anywhere between 70 and 90 percent of the pre-finishing labour costs in producing woollens. ${ }^{33}$

For Carus-Wilson, however, the true importance of the generally hilly, rural West Country regions, to explain why it indeed became the primary zone of the new English cloth industry, was in offering some of the best possible sites for mechanical fulling mills: with fast-flowing streams that could provide much more efficient and thus cheaper power for the traditional undershot water-wheels, which revolved by the direct impact of the river-flow on their veins or paddles; and, secondly, with lower opportunity-cost sites on such streams

pp. 369-76. For a response to these views and a new interpretation of the English crisis, see John Munro, "Origins of the English 'New Draperies," pp. 56, 66-8; and "The 'Industrial Crisis' of the English Textile Towns, 1290 - 1330," in Michael Prestwich, Richard Britnell, Robin Frame, eds., Thirteenth-Century England, 7 (1998), forthcoming.

${ }^{32}$ See the sources cited in the previous note, and in nn. 25, 28 above.

${ }^{33}$ Miller, "English Textile Industry," pp. 72-4, 77; Miller and Hatcher, Medieval England, pp. 10714, 120-7; and especially 95, Table 2.1. He estimated that spinning accounted for 40-50 percent, and weaving for 30-40 percent; and presumably his spinning-cost estimates including wool-preparation, combing (warps), and carding (wefts). 
in these much more sparsely settled and largely pastoral rural regions. ${ }^{34}$ The traditional eastern lowland textile towns and their immediately adjacent countrysides in contrast suffered from slow-moving streams, presumably too weak to power fulling mills. Furthermore, this far more densely populated urban region of latethirteenth-century England would have provided far more competition for the use of scarce river sites, especially in the larger towns, thus raising the opportunity costs in establishing fulling mills there.

Bridbury and other critics have pointed out, however, that from the time of Domesday thousands of water-mills can be found in eastern lowland England; and furthermore, that almost all of them served as grain mills, because most manorial lords and towns found flour-milling far more profitable than mechanical fulling. Indeed, very recently Richard Holt has endorsed that contention, after examining the revenues from hundreds of manorial accounts in this region. ${ }^{35}$ That valid point, however, does not really contradict the implicit assumptions of the opportunity-cost argument; and it is doubtful therefore that it would be equally valid for the more pastoral, thinly populated West Country, especially in the later Middle Ages (for reasons to be noted below).

Nevertheless, Carus-Wilson's critics have overlooked an important technological point: that these eastern mills, in using direct rotary power to grind flour, could not be so readily adapted for fulling. For fulling mills require cam shafts and trip-hammers to convert rotary into reciprocal power, i.e. to lift and drop the heavy oaken fulling-stocks. That in turn required a much a more efficient form of water power, which, however, could be produced by using overshot wheels on any slow-moving river. For they use only about one-quarter as much water as the former; and derive their power from the weight of the water falling on to the buckets attached to the wheel; and thus the speed of the stream is largely irrelevant. Their disadvantage, in terms of

${ }^{34}$ Carus-Wilson, "Industrial Revolution," pp. 183-210 (1954 edn. with some additions); see Miller, "English Textile Industry," p. 72. I have deduced from their writings, which do not employ this language, the basic economic principles involved in their arguments.

${ }^{35}$ Richard Holt, The Mills of Medieval England (Oxford, 1988), p. 158; see also Terry S. Reynolds, Stronger Than a Hundred Men: A History of the Vertical Water Wheel, Johns Hopkins Studies in the History of Technology, new series no. 7 (Baltimore, 1983), pp. 82-3, 113-14; Leslie Syson, British Water-Mills ( London, 1965), pp. 76-82. 
production costs, was a very large capital investment and much higher maintenance costs. Overshot-mills were far larger and more complicated in structure than undershot-mills, especially in requiring canals to divert the river water, mill ponds and sluice rates to store the water, and mill races with high wooden chutes to pour the water over the top of the wheel, i.e. onto the attached buckets. On the other hand, the location of these structures at some distance from the river may have meant lower opportunity costs and thus lower rentals than for undershot mills located directly on the river site, provided that the necessary canals did not impede river navigation, especially in dams to create millponds, or interfere with alternative uses of the river site. ${ }^{36}$

Furthermore, overshot wheels might have provided little assistance to the later-medieval English cloth industry, despite their far greater efficiency, because of their rather late introduction into England. The very earliest evidence for them comes from a depiction in the famous Luttrell Psalter of the 1330s; and another from an archeological site at Batsford, Sussex, of this same era. Historians of science seem generally agreed that overshot fulling mills were not widely used within England before the early sixteenth century. ${ }^{37}$ In two other respects, Carus-Wilson has misdated her 'English industrial revolution of the thirteenth century': first, long before any fulling-mills were established in England (1173), they were being used in Italy (from 962) and Normany (from 1086); and, secondly, in England, far many more can be dated from after the 1340s than from

${ }^{36}$ Holt, Mills, p. 157, also denying that mills in the south-west, with swifter streams, were any more profitable; but for contrary evidence, see below p. and nn. 67-9 below. The comprehensive map in R. A. Pelham, Fulling Mills, Society for the Protection of Ancient Buildings, no. 5 (1958), reprinted in Bridbury (1982), 18, demonstrates that the very regions cited by Carus-Wilson, for offering the best locations for fullingmills -- namely the south-west and the north -- were the very regions contained the overwhelming majority of fulling-mill sites. In response Bridbury retorted (p. 17) "that mills were frequently situated in parts of the country where labour supplies were least satisfactory, where raw materials were poor, and where markets were relatively inaccessible," such as Cornwall, southern Wales, and the Lake District, which never became important cloth-manufacturing centres. While that is a fair comment, neverthless the West Country and West Riding of Yorkshire did become two of the three leading centres for the reviving English cloth industry after the mid-fourteenth century.

37 Reynolds, Water-Wheel, pp. 10-14, 25-6, 36-46, 97-102; Syson, Water-Mills, pp. 76-82 (see overshot wheel in figure 28, p. 64, from Agricola, De Re Metallica of 1556); Holt, Mills, pp. 128-31: with an overshot wheel shown in Plate 3, p. 130, of the famous fourteenth-century Luttrell Psalter. 
before. $^{38}$

Certainly from the mid- to later fourteenth century, a large number of chiefly undershot fulling mills came to be employed throughout the English woollen industry; and Carus-Wilson's critics have been unfair in dismissing the longer term cost advantages of this mechanical process. For quite precise data from latermedieval and early-modern textile industries in the Low Countries and Italy (Florence) indicate, by various comparisons, that fulling-mills provided about a 70 percent gain over foot-fulling; and, in the late-medieval Flemish and Dutch draperies, foot-fulling accounted for about 20 percent of the draper's valued-added manufacturing costs, which could certainly mean a major difference between his profit or loss. ${ }^{39}$ Such comparisons, however, may indeed be valid only from the later-medieval and post-Plague era, when fulling mills may have acquired or increased their relative cost advantages for two major reasons: (1) the evident rise in real wages and thus labour costs, possibly if not indisputably the consequence of drastic depopulations and

${ }^{38}$ Paolo Malanima, "The First European Textile Machine," Textile History, 17 (1986), 115 - 28, for the very early fulling mills in Italy and France. The map in Pelham, Fulling Mills, indicates that more fulling mills were established after 1330 than before, especially in the West Country; and Kenneth Ponting, The Woollen Industry of South-West England: An Industrial, Economic, and Technical Survey (Bath, 1971), pp. 15-16, also contends that the fourteenth rather than the thirteenth century was the real era for the diffusion of fulling mills within England.

${ }^{39}$ Foot-fulling at Leuven and Leiden in the 1430s (for high quality woollens made from English wools) accounted for 22.5 percent of pre-finishing costs, compared to a share of just 5.1 percent for water-powered fulling in the Medici's Florentine drapery (in the 1550s). For evidence, see Posthumus, Bronnen, i: passim; Stadsarchief Leuven, no. 5058 (1434-5) and no. 5072 (1442-43); Raymond Van Uytven, Stadsfinanciën en Stadsekonomie te Leuven van de XIIe tot het einde er XVIe eeuw (Brussels, 1961), p. 343; Raymond De Roover, "A Florentine Cloth Firm of Cloth Manufacturers: Management of a Sixteenth-Century Business", Speculum, 16 (1941), 32-33; reprinted in his Business, Banking, and Economic Thought in Late Medieval and Early Modern Europe: Selected Studies of Raymond De Roover, ed. Julius Kirshner (Chicago, 1974), pp. 85-118. Estimates of a 35-fold gain, which seem excessive, are given in Walter Endrei, "Changements dans la productivité de l'industrie lainière au moyen âge," Annales: E.S.C,, 26 (1971), 1296-98. But see Raymond Van Uytven, "De volmollen: motor van de omwenteling in de industrielle mentaliteit", Tijdschrift van de kring der alumni van de wetenschappelijke stichtigen, 38 (1968), pp. 61 -76, republished as "The Fulling Mill: Dynamic of the Revolution in Industrial Attitudes", Acta Historiae Neerlandica, 5 (1971), 1-14; Raymond Van Uytven, "Technique, productivité, et production au moyen âge: le cas de la draperie urbaine aux Pays-Bas", in S. Mariotti, ed., Produttività e tecnologia nei secoli XII-XVII (Florence, 1981), pp. 285-86. He provides a much more modest estimate of a 3.3 fold productivity gain for the fulling-mill, though not believing that it made a significant difference to the total price of a cloth. The issue, however, is not total costs and price, but "value-added" manufacturing costs. See also John Munro, "Textile Technology," pp. 705-7; and John Munro, "Industrial Entrepreneurship," pp. 377-88. 
consequent changes in the land:labour ratios; (2) a relative fall in grain prices -- relative to textile prices -especially by the early to mid fifteenth century, which may have reduced the opportunity costs of using a watermill for cloth fulling, especially if many grain mills had fallen out of use with the sparser populations and the falling demand for grain and thus falling prices for flour.

As her final argument in justifying her view for the later-medieval rural predominance of the English cloth industry, and also in providing yet another reason why the English cloth industry was necesarily transferred from the eastern towns to the countryside, during the later thirteenth century, one that few if any of her critics have disputed, Carus-Wilson contended that deeply entrenched opposition from urban fullers' guilds would have prevented the installation of any such device that threatened technological unemployment. But she provided at the most very misleading evidence for this view; ${ }^{40}$ and grossly exaggerated the negative power of such craft guilds, which, according to recent historians of late-medieval English towns, were really subservient to merchant-dominated urban governments and did not impede industrial innovations. ${ }^{41}$

\section{Crises in English and Flemish Textile Manufacturing, 1290 - 1340: Mediterranean and west European Warfare, rising transaction costs, and industrial reorientation}

As I have argued at length elsewhere, the undisputed decline of the major textile towns in eastern England had nothing whatsoever to do with fulling mills, urban guilds, town governments, taxation, or various other other urban resrictions or impediments cited to explain a supposed but undocumented rise in industrial

40 Carus-Wilson, “Industrial Revolution,” pp. 194-209 (1954 edn); Carus-Wilson, "Woollen Industry," pp. 667-73 (1987 edn. While the London fullers attempted, in 1298, to forbid anyone from using fulling mills (all outside the town), they succeeded only in forbidding anyone who was not the owner of the cloth to do so. See H. Thomas Riley, ed., Munimenta Gildhallae Londoniensis: Liber Albus, Liber Custumarum et Liber Horn (1859-62), II.i: Liber Custumarum, pp. 128-29: 'ne face porter, mener, ne bailler, hors de la cite nul drap pur foller as molins, fors ceux memes a qui les draps serront, et les queus draps il voillent pur lour avower'. (26 Edward I). For Winchester and other urban draperies that did use fulling mills, see nn. 67-9, below.

${ }^{41}$ See in particular Heather Swanson, "The Illusion of Economic Structure: Craft Guilds in Late Medieval English Towns," Past \& Present, no. 121 (November 1988), pp. 29 - 48; Heather Swanson, Medieval Artisans: An Urban Class in Late Medieval England (Oxford, 1989), pp. 26-44, 107-26. 
costs and thus supposed but unproven industrial exodus to the countryside. ${ }^{42}$ Nor did it have anything to do with any 'growing influx' of Flemish and Brabantine woollens, a contention also quite unproved in all respects, and also unbelievable with the current industrial crisis that the major drapery towns in the cross-Channel Low Countries were themselves then undergoing. On the contrary, these traditional English textile towns had devoted their export-oriented production during the twelfth and thirteenth centuries primarily to very cheap and light fabrics directed principally to the populous Mediterranean towns (Christian and Muslim), with warm climates that provided ready markets for such textiles; that most of the imports of Flemish and Brabantine textiles were far higher quality and more expensive woollens, whose commerce did not vitally affect the traditional English textile industries; and that their unquestionably severe 'industrial crisis', from the 1290s to the 1330s, was the consequence of exactly the same set of destructive forces that were inflicting, at this very same time, an equally severe crisis upon the cheaper-line sayetteries and other draperies légéres, in towns large and small, in both Flanders and Brabant. That very complex set of negative economic factors was collectively bred by warfare throughout the entire Mediterranean basin, in western Christian, Byzantine, and Muslim realms alike, and in western Europe itself, from the 1290s, and by the consequent disruptions to the long-established European trade networks.

To be sure, one might well cavil that warfare had never been absent from medieval Europe; but, from from the 1290s, warfare became far more widespread, chronic, indeed incessant, and far more costly and destructive to commerce, especially in the Mediterranean basin, than it had been earlier, in the twelfth and thirteenth centuries. ${ }^{43}$ Flanders' own immediate plight began much closer to home, with the Anglo-French and

${ }^{42}$ See John Munro, "Industrial Crisis," forthcoming; see also Munro, "Industrial Transformations," pp. 59-76; Munro, "Origins of the English 'New Draperies'," pp. 56-83. The chief towns were York, Louth, Beverley, Lincoln, Stamford, Northampton, Leicester, Huntingdon, Norwich, Colchester, Oxford, Winchester, and London.

${ }^{43}$ For the following, see Munro in n. 42 above; and also John Munro, "'Patterns of Trade, Money, and Credit," in James Tracy, Thomas Brady Jr., and Heiko Oberman, eds., Handbook of European History in the Later Middle Ages, Renaissance and Reformation, 1400 - 1600, Vol. I: Structures and Assertions (Leiden: E.J. Brill, 1994), pp. 147-95. 
Franco-Flemish wars, from 1293 to 1318 , severely disrupting not only cloth production but even more the Champagne Fairs, which had served as the principal trading conduit to the Mediterranean basin, where most of Flanders' says and other cheap, light fabrics had been sold. ${ }^{44}$ In the western Mediterranean itself, commercial disruptions had begun even earlier, with the Sicilian Vespers War of 1282-1302, involving most of Italy, France, Catalonia, and Aragon; these Spanish kingdoms and Castile then became embroiled in chronic, destructive warfare with neighbouring Muslim states (Granada, Morocco, Tlemcen) from 1291 to 1340. Meanwhile, in Italy, the Sicilian Vespers had resumed as the Guelf-Ghibelline Wars of 1313-43, involving almost continuous foreign intervention, by Catalan, French, German, and Hungarian armies; and indeed, in the late 1320s, an Italian merchant blamed these wars for his inability to transport northern woollens from the Champagne Fairs to Genoa. ${ }^{45}$ Those wars were accompanied and then followed by incessant campaigns of mercenary Free Companies, who ravaged Italy north to south from the 1330 s to the 1360 s. ${ }^{46}$ In the eastern

${ }^{44}$ See in particular Patrick Chorley, "The Cloth Exports of Flanders and Northern France During the Thirteenth Century: A Luxury Trade?" Economic History Review, 2nd ser. 40:3 (August 1987), 349-79; and Chorley, "English Cloth Exports," pp. 1-10; Joseph R. Strayer, "The Costs and Profits of War: The AngloFrench Conflict of 1294-1303," in David Herlihy, H.A. Miskimin, and A. Udovitch, eds., The Medieval City (London and New Haven, 1977), pp. 269-91; and Robert-Henri Bautier, "Les foires de Champagne: recherches sur une evolution historique," Bulletin de la société Jean Bodin, V: La foire (Paris, 1953), pp. 97-145; republished in English trans. as "The Fairs of Champagne," in Rondo Cameron, ed., Essays in French Economic History (Homewood, Ill., 1970), pp. 42-63, who gives other reasons as well for the decline of the Fairs, most notably "Italian industrialization." But Hoshino, L'arte della lana in Firenze (1980) and in "Rise of the Florentine Woollen Industry" (1983), pp. 184-204, shows that the real growth of the Florentine woollen industry came from the 1320s, after the full decline of the Champagne Fairs; but he e conversely attributes the rise of the Florentine industry to the Flemish crises.

${ }^{45}$ For the complaints of the Italian merchant on disruptions in the overland cloth trade, in May 1327: "nec per terra ire potuit communiter propter guerras que presentaliter occurentes inter Januinos guelfos et guibelines...", see Renée Doehaerd, ed., Les relations commerciales entre Gênes, la Belgique, et l'Outremont, d'après les archives notariales génoises aux XIIIe et XIVe siècles, 3 vols. Institut Historique Belge de Rome: Etudes d'Histoire Economique et Sociale (Brussels: Palais des Academies, 1941), III, no. 1869, p. 1156. This collection of Genoese notarial documents records a wide range of cheap, light northern textiles exported to the Mediterranean up to ca. 1320, but very few thereafter -- just some "Irish says" of unknown provenance.

${ }^{46}$ For the foregoing, see Edouard Baratier and Félix Reynaud, Histoire du commerce de Marseille, II: De 1291 à 1480 (Paris, 1951), pp. 23-40, 304-13; G. Mollat, The Popes at Avignon: The 'Babylonian Captivity' of the Medieval Church, 9th edn. trans. Janet Love (New York, 1963), pp. 67-228; Edward Armstrong, "Italy in the Age of Dante," in J. R. Tanner, C. W. Previté-Orton, and Z. N. Brooke, eds., The Cambridge Medieval History, Vol. VII: Decline of Empire and Papacy (Cambridge, 1958), pp. 1 - 48; 
Mediterranean, commercial disruptions had also begun in 1291, with the Mamluk conquest of Crusader Palestine, followed by papal bans on Muslim trade, the Genoese-Venetian naval wars (1291-99), Turkish advances into the Byzantine Empire from 1303, then depredations of Catalan mercenaries sent to oppose them (1303-12), and finally, from the 1330s, anarchic warfare in the Mongol khanates and Persia, which had become so important to Italian trade. ${ }^{47}$ Immediately thereafter, the outbreak of the Hundred Years War (1337-1453), and then onslaughts of bubonic plague, ensured almost continuous commercial disruptions well into the fifteenth century.

Of course, despite all these adverse conditions, an international trade in textiles continued throughout the later Middle Ages, but it came to be conducted in much smaller volumes, with chiefly high value cargoes, at far higher unit costs. Both transportation and a much broader range of transaction costs rose sharply, not so much from warfare itself as from the almost incessant piracy, brigandage, and trade bans that accompanied these wars $;^{48}$ and from the various forms of war-financing, in high taxes and interest rates, trade licences at exorbitant prices, and coinage debasements. ${ }^{49}$ Furthermore, because the transactions sector was subject to large

Charles-Emmanuel Dufourcq, L'Espagne catalane et le Maghrib aux XIIIe et XIVe siècles: de la bataille de Las Navas de Tolosa (1212) à l'avènement du sultan mérinide Abou-l-Hasan (1331) (Paris: Presses universitaires de France, 1966), (1966), pp. 193-587; and sources in nn. 42-43.

${ }^{47}$, ed. by Mark Steele, Variorum Reprints CS286 (London, 1988), especially "Le commerce terrestre de Marseille au XIIIe siècle" [from Revue historique, 163 (paris, 1930, 27-50.]. Western states also utilized Crete, Cyprus, and Lajazzo (in Cilicia or "Lesser Armenia") as intermediaries to conduct trade with the Muslim Levant, but paid a higher price in doing so. Lajazzo was conquered by the Mamluks in 1347.

${ }^{48}$ For evidence on this, see sources cited in nn. 43-44, 46; and also Henri Bresc, Un monde méditerranéen: Économie et société en Sicile, 1300 - 1450, 2 vols., Bibliothèque des Écoles françaises d'Athènes et de Rome, no. 262 ( Rome, 1986), I, tables 67, 69, 130, 138, pp. 317, 326, 534, 549.

${ }^{49}$ For a detailed analysis of overland transport costs in medieval Europe, especially including taxes and tolls, see Michael Postan, "The Trade of Medieval Europe: the North," in M.M. Postan and Edward Miller, eds., The Cambridge Economic History of Europe, Vol. II: Trade and Industry in the Middle Ages, 2nd rev. edn. (Cambridge, 1987), pp. 182-204, emphasizing that "local taxation, war and piracy became more disturbing and more difficult to circumvent as the Middle Ages drew to their close" (p. 204). Postan argues, however, that before then transaction costs may have accounted for a smaller proportion of total costs than in modern times, because much greater economies have been achieved in production than in trading since the medieval era. See also evidence on transport costs in Robert-Henri Bautier, Sur l'histoire économique de la France médiévale: la route, le fleuve, la foire (London and Brookfield, Vt., 1991). 
scale-economies, depopulations and market contractions themselves raised these unit costs even further. ${ }^{50}$

In a similar vein, Van der Wee has argued that disruptions to the arterial continental trade routes, and in particular those involving the rapidly declining Champagne Fairs, which earlier, in the thirteenth century, had been so vital to European prosperity, produced a severe commercial contraction and then periodic depressions during the fourteenth and early fifteenth centuries. Reductions in commercial transactions on these routes had very adverse multiplier-accelerator effects, through falling investment, employment, and consumption, radiating through a complex myriad of interlacing subsidiary networks for regional and local trade, which had once served thousands of towns and villages over a vast hinterland. ${ }^{51}$ While a consequent shift to maritime trade may have benefited a periphery of European coastal towns, their relative prosperity could not possibly have compensated, in his view, for the economic decline in the much larger continental

50 See Douglass North, "Government and the Cost of Exchange in History," Journal of Economic History, 44:2 (June 1984), 255-64; Douglass North, "Transaction Costs in History," Journal of European Economic History, 14:3 (Winter 1985), 557-76; Douglass C. North and Robert P. Thomas, The Rise of the Western World: A New Economic History (Cambridge, 1973), pp. 79-85, 89, 93-94, 134-38; Clyde G. Reed, "Transactions Costs and Differential Growth in Seventeenth Century Western Europe," Journal of Economic History, 33:1 (March 1973), 177 - 90, especially pp. 180-6. The transactions sector contains a relatively large fixed-cost component, with a declining, constant, or even rising marginal cost component that is small relative to initial fixed costs. In North-Thomas's view (pp. 93-4), certain fixed costs are involved in each of the three essential components of the transactions sector: search and enforcement costs especially, negotiation (and transportation) to a lesser extent: "as the scale of transactions increases, the unit cost of using the market declines."

${ }^{51}$ Herman Van der Wee and Theo Peeters, "Un modèle dynamique de croissance interseculaire du commerce mondiale, XIIe - XVIIIe siècles," Annales: économies, sociétés, civilisations, 15 (1970), 100-28. Thus in 1397, a Bruges-based Italian merchant writing to his Barcelona agent noted that "only cloths of high value can bear the costs of land transport, the others not." The next year, another Italian merchant at Bruges stated that shipping luxury-quality Wervik woolens to Barcelona by sea would cost 15.2 percent of the price, or 21.7 percent by land, observing that some other merchants who had recently sent cloths overland had "lost all their profit." But 80 years earlier, transporting Caen says overland to Florence, via the Rhone route (the only safe route), had cost only 8.8 per cent of their much lower value (11.5 florins). See Federigo Melis , "La diffusione nel Mediterranea occidentale dei panni di Wervicq e delle altre citta della Lys attorna al 1400," in Studi in onore di Amintore Fanfani, III: Medioevo (Milan, 1962), pp. 233-4, n. 30; Armando Sapori, Una compagnia di calimala ai primi del trecento, Biblioteca storica toscana, Vol. 7 (Florence, 1932), pp. 97-99: see also Chorley, "L uxury Cloth," p. 369; Munro, "Industrial Transformations," p. 129; Munro, "Origins of the English "New Draperies," pp. 81-3. Comparing relative values is difficult, except to note that the 1320 s was an era of inflation, while the 1390s was one of severe deflation, with a much lower gold: silver ratio. 
hinterland. $^{52}$ Furthermore, not only were the costs of Mediterranean sea-borne trade significantly raised from the 1290s, for reasons just noted; but so were those on Atlantic and Baltic sea routes, with naval warfare and chronic piracy throughout the fourteenth and early fifteenth centuries. ${ }^{53}$

Under such worsening, chronically adverse circumstances, many European textile manufacturers undoubtedly found that long-distance trade in cheap textiles was becoming unprofitable during the early fourteenth century: that transport and transaction costs too frequently rose above the floor-price set for such textiles. Clearly most threatened with extinction were those northern producers, Franco-Flemish, Brabantine, and English drapers alike, who had exported most of their output of cheap textiles over such long distances to Mediterranean markets, essentially as 'price-takers', under conditions approaching perfect competition (i.e.

${ }^{52}$ Nor can we safely assume that a shift to maritime trade meant economic advancement: for then there would be considerable difficulty in explaining both the revival of continental overland trade routes and the rise of new inland international fairs, and consequent European economic expansion, during the later fifteenth and sixteenth centuries. See Munro, "Origins of the English "New Draperies," pp. 85-87; Munro, "Patterns of Trade," pp. 153-7, 165-81; Van der Wee and Peeters, “Commerce mondiale," pp. 100-28.

${ }^{53}$ Italian galley fleets thus made only infrequent voyages to Flanders during the fourteenth century. In only 35 percent of the years from the first state subsidies in 1332 to 1400 did Venetian galleys reach Bruges. Alberto Tenenti and Corrado Vivanti, "Le film d'un grand système de navigation: Les galères marchandes vénitiennes, XIV ${ }^{\mathrm{e}}$ - XVI ${ }^{\mathrm{e}}$ siècles," Annales: économies, sociétés, civilisations, 16 (Jan.-June 1961), 83-86. Sea transport was not so cheap, when, for example, shipping salt from Portugal to Bruges ca. 1400 accounted for 85 percent of the landed price; shipping Baltic grain to Bruges, ca. 1400, accounted for about 50 percent of the landed price. Richard Unger, The Ship in the Medieval Economy, 600-1600 (London: Croom Helm, 1980), p. 169. The costs of handling and shipping Cotswolds wool to Venice, ca. 1465 were as follows: (a) purchase price per sack, £8.0s.0d.; (b) packing and transporting to Southampton: 13s.4d. (= 8.33 percent of the purchase price); (c) alien customs and subsidy: $£ 2.13 \mathrm{~s} .4 \mathrm{~d}$. (33.33\%); (d) Freight charges on Venetian state galley: $£ 2.0 \mathrm{~s} .0 \mathrm{~d}(25.0 \%)$; (e) other handling charges and taxes at Venice: $£ 1.4 \mathrm{~s} .4 \mathrm{~d}$. (15.2\%); (f) thus total charges = $£ 6.11 \mathrm{~s} .0 \mathrm{~d}(81.9 \%)$; (g) sales price at Venice: $£ 20.0 \mathrm{~s} .0 \mathrm{~d}$., for a profit of $£ 5.9 \mathrm{~s} .0 \mathrm{~d}$. "Noumbre of Weyghtes," cited in E. B. Fryde, "Anglo-Italian Commerce in the Fifteenth Century: Some Evidence about Profits and the Balance of Trade," Revue belge de philologie et d'histoire, 50 (1972), 345-55; E. B. Fryde, "Italian Maritime Trade with Medieval England (ca. 1270 - c. 1530)," Recueils de la société Jean Bodin, 32 (1974), 291 - 337; both reprinted in his Studies in Medieval Trade and Finance (London, 1983). He notes, however, that Genoese freight rates (by carrack) for wool were 5.16 percent of the price (8s.3d. per sack); those for alum and woad, about 8 percent of their prices. On Mediterranean naval wars and related piracy in the 14th century, see Baratier and Reynaud, Marseille, pp. 36-37; Kedar, Merchants in Crisis, pp. 28-38; Sayous, "Transfert de risuqes," pp. 476-83; and various studies of Frederic Lane in Venice and History: The Collected Papers of Frederic C. Lane (Baltimore, 1966); Frederic Lane, "The Crossbow in the Nautical Revolution of the Middle Ages," in David Herlihy, Robert Lopez, and Vsevolod Slessarev, eds., Economy, Society, and Government in Medieval Italy: Essays in Memory of Robert L. Reynolds (Kent, Ohio: Kent State University Press, 1969), pp. 161-72; Katele, "Piracy and the Venetian State," pp. 865-89. 
with almost flat demand curves). While a very wide range of cheap fabrics had been marketed in the late thirteenth century, any producer's particular fabric in the lowest-price categories -- a biffe, say, serge, fustian, or coarse light woollen -- was very similar to rival fabrics sold by thousands of other drapers, who individually had almost no power to set prices in these southern markets, especially when they evidently became fully saturated, around $1300 . .^{54}$

As the combination of production, transport, and transaction costs in exporting such texiles to the Mediterranean basin rose above the prevailing market prices in those regions, producers of those cheap light textiles were evidently forced out of production; and the drapers best able to survive under such adverse conditions were those who produced the far higher-value luxury woollens, for which the rising transport and transaction costs thus represented a much smaller proportion of total costs and thus of these high prices, with indeed a relatively low degree of price-elasticity of demand ('inelastic'), and one that such drapers were better able to influence. While the Flemish, Artesian, and the Brabantine towns had indeed become famous for their high quality woollens well before 1300 , such woollens had in fact constituted only a small segment of this region's aggregate textile production during the twelfth, thirteenth, and very early fourteenth centuries, though presumably a larger segment than had been true of the thirteenth-century English cloth production, for which only the Lincoln 'scarlets' had had any genuine significance in luxury production. ${ }^{55}$

\section{Possible Demand Factors in the Industrial Re-orientation of European Textile Manufacturing}

Furthermore, during or by the early fourteenth century, the structure of European demand may have

${ }^{54}$ Hoshino, "Rise of the Florentine Woollen Industry," p. 195, has pertinently noted that "because of the demand for common cloth [in Mediterranean markets around 1300] many cities competed for the same market with materials which were qualitatively identical."

${ }^{55}$ See E. M. Carus-Wilson, "Trends in the Export of English Woollens in the Fourteenth Century," Economic History Review, 2nd ser., 3:2 (1950); reprinted in her Medieval Merchant Venturers: Collected Studies (London: Methuen, 1954), pp. 239 - 64; Chorley, "Luxury Trade?," pp. 349-87; Chorley, "English Cloth Exports," pp. 1-10; Childs, "English Export Trade," pp. 121-47; Munro, "Industrial Transformations," pp. 110-48; Munro, "Origins of the English 'New Draperies"," pp. 35-127; Munro, "Industrial Crisis" (forthcoming). 
become less propitious for marketing the cheaper textiles. Thus, as many historians currently argue, western Europe, after having experienced unprecedented population growth during the so-called 'long thirteenth century' (c.1180-c.1315), may have experienced a 'Malthusian crisis', one that grievously aggravated the consequences of the 'Great Famine' of 1315-22, even if its basic causes lay in vagaries of the climate. ${ }^{56}$ The Malthusian proponents have found their best demographic evidence in England, contending that by 1300 it had over six or even seven million inhabitants, well in excess of its population on the eve of the Industrial Revolution; and several recent studies on East Anglia and Norfolk cite data that suggest an intensifying immiserization in overcrowded villages. ${ }^{57}$ But more recent studies have reduced the pre-Famine English population estimates to a more credible four million; and, furthermore, a close analysis of the Phelps Brown \& Hopkins wage and price data (chiefly for the Oxford-Cambridge region) do not show any appreciable

56 The most eloquent case for a Malthusian crisis is made in Michael Postan, Essays on Medieval Agriculture and General Problems of the Medieval Economy (Cambridge, 1973), pp. 186 - 213. See William C. Jordan, The Great Famine: Northern Europe in the Early Fourteenth Century (Princeton: Princeton University Press, 1996); Henry Lucas, "The Great European Famine of 1315, 1316, and 1317," Speculum, 5 (1930), reprinted in E.M. Carus-Wilson, ed., Essays in Economic History, Vol. II (London, 1962), pp. 4972.; Ian Kershaw, "The Great Famine and Agrarian Crisis in England, 1315-1322," Past and Present, no. 59 (May 1973), 3-50; reprinted in R.H. Hilton, ed., Peasants, Knights, and Heretics (Cambridge, 1976), pp. 85132; Wilhelm Abel, Agricultural Fluctuations in Europe from the Thirteenth to the Twentieth Centuries, 3rd edn., (Berlin, 1978); trans. Olive Ordish (London, 1980), chapters 1-3; L. R. Poos, "The Historical Demography of Renaissance Europe: Recent Research and Current Issues," Renaissance Quarterly, 42 (1989), 749-811; Richard M. Smith, "Demographic developments in rural England, 1300-48: a survey," in Bruce M.S. Campbell, ed., Before the Black Death: Studies in 'Crisis' of the Early Fourteenth Century (Manchester and New York, 1991), pp. 25-78. The most effective cases against the Malthusian model are made in: A.R. Bridbury, "Before the Black Death," Economic History Review, 2nd ser. 30 (1977), 393-410; and Barbara Harvey, "The Population Trend in England Between 1300 and 1348," Transactions of the Royal Historical Society, 5th ser. 16 (1966), 23-42.

57 H. E. Hallam, "Population Movements in England, 1086 - 1350," and "Rural England and Wales, 1042 - 1350," in H. E. Hallam, ed., The Agrarian History of England and Wales, II: 1042 - 1350 (Cambridge, 1988), pp. 508 - 93, and 966 - 1008; L. R. Poos, "The Rural Population of Essex in the Later Middle Ages," Economic History Review, 2nd ser. 38 (November 1985), 515 - 30; L. R. Poos, A Rural Society after the Black Death: Essex, 1350 - 1525, Cambridge Studies in Population, Economy and Society in Past Time no. 18 (Cambridge, 1991); Bruce M. Campbell, "Population Pressure, Inheritance, and the Land Market in a Fourteenth-Century Peasant Community," in Richard M. Smith, ed., Land, Kinship and Life-Cycle (Cambridge, 1984), pp. 87 - 134. 
declines in real wages from c. 1290 to $1315 .^{58}$ Elsewhere in Europe, evidence for a sudden fall in population from the early fourteenth-century, especially in Provence and Tuscany, probably reflect the consequences of debilitating warfare and economic crises rather than genuine Malthusian crises. ${ }^{59}$

Nevertheless, in many parts of western Europe rising taxation combined with all the other war-related economic factors that combined to raise transaction costs in marketing cheaper cloths may have produced more highly skewed income distributions, especially in depressing real incomes amongst the lower classes, that reinforced this same relative shift towards the higher-priced, more luxury oriented textiles in international trade: ${ }^{60}$ i.e. fine woollens, linens, and silks. ${ }^{61}$ For the post-Plague era of rapid depopulations, which also included most of the Hundred Years' War era (1337-1453), Lopez, Herlihy, Van der Wee and other historians have produced evidence of increasing poverty in many parts of Europe, countering the contentions of many

${ }^{58}$ Henry Phelps Brown and Sheila V. Hopkins, "Seven Centuries of the Prices of Consumables Compared with Builders' Wage-rates," Economica, 23:92 (November 1956), reprinted in their A Perspective of Wages and Prices (London and New York: Methuen, 1981), pp. 13-59 (with additional statistical appendices not in the original).

${ }^{59}$ Georges Lesage, Marseille angevine: recherches sur son evolution administrative économique et urbaine de la victoire de Charles d'Anjou à l'arrivée de Jeanne Ire (1264 - 1348) (Paris, 1950), doc. no. 6, p. 184 (October 1331); David Herlihyand Christiane Klapisch-Zuber, Tuscans and Their Families: A Study of the Florentine Catasto of 1427 (London and New Haven, 1985), pp. 60-92..

${ }^{60}$ See the evidence cited in Munro, "Industrial Transformations," pp. 120-39; and a discussion of the highly problematic 'demographic real-income model', pp.139-41; and in Munro, "New Draperies," pp. 70-87. The demand model is all the more problematic in that many of the major Mediterranean customers for cheap textiles were aristocratic households that purchased them as livery for their servants; and thus they would have been less affected by these demand factors.

${ }^{61}$ Such views, however, would seem to contradict the widely held assumption that late-medieval depopulation rewarded the lower classes with rising real incomes (or wages). But much evidence indicates that the post-plague inflations nullified money-wage gains and that even in stable England and the Low Countries real wages did not rise until the onset of deflation in the late fourteenth, early fifteenth century. Thus any such rise in real wages came far too late to explain the industrial changes just outlined. See Munro, "Industrial Transformations", pp. 139-43; John Munro, "Mint Outputs, Money, and Prices in Late-Medieval England and the Low Countries," in Eddy Van Cauwenberghe and Franz Irsigler, eds., Münzprägung, Geldumlauf und Wechselkurse/Minting, Monetary Circulation and Exchange Rates, Trierer Historische Forschungen, Vol. 7: Akten des 8th International Economic History Congress, Section C-7, Budapest 1982 (Trier, 1984), pp. 31-122; Phelps Brown and Hopkins, Perspective, tables pp. 45-50; A. R. Bridbury, "The Black Death," Economic History Review, 2nd ser. 26 (1973), 557-92. 
other historians that such depopulations resulted in rising living standards amongst the lower strata of western society. ${ }^{62}$ For England and the Low Countries, with the best wage and price data,

${ }^{62}$ See Michael Prestwich, War, Politics, and Finance Under Edward I (London, 1972); Michael Prestwich, "Currency and the Economy of Early Fourteenth Century England," in Nicholas J. Mayhew, ed., Edwardian Monetary Affairs, 1279 - 1344, British Archaeological Reports no. 36 (Oxford, 1977), pp. 45 58; Michael Prestwich, The Three Edwards: War and State in England, 1272 - 1377 (London, 1980), chapters 1, 2, and 9; J. R. Maddicott, The English Peasantry and the Demands of the Crown, 1291 - 1341, Past and Present Supplement no. 1 (Oxford, 1975); reprinted in T. H. Aston, ed., Landlords, Peasants, and Politics in Medieval England (Cambridge, 1987), pp. 285 - 360; Edward Miller, "War, Taxation, and the English Economy in the Late Thirteenth and Early Fourteenth Century," in J.M. Winter, ed., War and Economic Development: Essays in Memory of David Joslin (Cambridge, 1975), pp. 11-32. Their views, however, have been disputed by A.R. Bridbury, "The Hundred Years' War: Costs and Profits' in D.C. Coleman and A.H. John, eds., Trade, Government, and Economy in Pre-Industrial England (London, 1976), pp. 80 - 95 and Bridbury, "Before the Black Death" (1977), pp. 393-410, but with arguments contradicting some of those in his earlier "The Black Death" (1973), pp. 557-92. On the consequences of war financing, see also E.B. Fryde, "Financial Resources of Edward I in the Netherlands, 1294-98: Main Problems and Some Comparisons with Edward III in 1337-40," Revue belge de philologie et d'histoire, 40 (1962), 1168-87 E. B. Fryde, "Financial Policies of the Royal Governments and Popular Resistance to Them in France and England, 1270-1420," Revue belge de philologie et d'histoire, 57 (1979), 824-60; reprinted in Reprinted in E. B. Fryde, Studies in Medieval Trade and Finance (London,1983), no. I (1962), pp. 1168-87, and (1979), pp. 824-60; Philippe Contamine, Guerre, état et société à la fin du moyen âge: études sur les armées des rois de France, 1337-1494 (Paris, 1972); Philippe Contamine, "La guerre de Cent Ans en France: une approche économique," Bulletin of the Institute of Historical Research, University of London, 48 (1974), 125-49; Philippe Contamine, War in the Middle Ages (London, 1984), pp. 119-72, 238-49; Prestwich, Three Edwards, pp. 245-300; Edouard Perroy, The Hundred Years' War, trans. David Douglas (London, 1959), chapters 4-5. For income effects and concentration of wealth, see Robert Lopez, "Hard Times and Investment in Culture," in The Renaissance: A Symposium, Metropolitan Museum of Art (New York, 1953), pp. 19-32; reprinted in Anthony Molho, ed., Social and Economic Foundations of the Italian Renaissance (London and New York: 1969), pp. 95-116; Harry A. Miskimin, The Economy of Early Renaissance Europe, 1300-1460 (1969; reissued Cambridge, 1975), especially pp. 132-63; David Herlihy, Medieval and Renaissance Pistoia: The Social History of an Italian Town, 1200-1430 (New Haven and London, 1967), especially pp. 180-97; David Herlihy, "Family and Property in Renaissance Florence," in Harry Miskimin, David Herlihy, and Avrom Udovitch, eds., The Medieval City ( New Haven and London, 1977), pp. 3-24; David Herlihy, "The Distribution of Wealth in a Renaissance Community: Florence 1427," in Philip Abrams and E.A. Wrigley, ed., Towns in Societies: Essays in Economic History and Historical Sociology (Cambridge, 1978), pp. 131-58; Herlihy and KlapischZuber, Tuscans (1985), pp. 93-130; Kedar, Merchants in Crisis (1976), chapters 3-6; Van der Wee and Peeters, "Commerce Mondiale," pp. 100-28; Michael Mollat and Philippe Wolff, The Popular Revolutions of the Late Middle Ages (London, 1973), especially chapter 3: "Revolts Against Poverty," pp. 91-137; Michel Mollat, Les pauvres au moyen âge: étude sociale (Paris, 1978); republished as The Poor in the Middle Ages (Yale University Press, New Haven, 1986); R. Cazelles, "Quelques reflexions à propos des mutations monétaires de la monnaie royale française (1295-1360)", Le moyen âge, 72 (1966), 83-105, and 251-78; Edouard Perroy, "A l'origine d'une économie contractée: les crises du XIV ${ }^{\mathrm{e}}$ siècle," Annales: E.S.C., 4 (1949), 167-82, republished as: "At the Origin of a Contracted Economy: The Crises of the 14th Century," in Rondo Cameron, ed., Essays in French Economic History (Homewood, Illinois, 1970), pp. 91-105; Edouard Perroy, "Wage Labour in France in the Later Middle Ages," Economic History Review, 2nd ser. 7 (1955), reprinted in Sylvia Thrupp, ed., Change in Medieval Society: Europe North of the Alps, 1050-1500, (New York, 
such a rise is not evident before the late fourteenth century; and for the rest of later-medieval Europe there can be little certitude about changing trends in real incomes. ${ }^{63}$

There remain two other problems that make a demand-oriented economic model of industrial reorientation problematic. First, in Mediterranean markets, many of the very major customers for says and other cheap textiles were aristocratic households, which purchased them as livery for their servants, and sometimes as alms for the poor; and such households would thus been much less influenced by such changes in demand in making thier purchases. Secondly, the evidence for later-medieval Mediterranean cloth sales in particular does not really indicate that the best markets were for the very highest priced most luxurious textiles. On the contrary, some cheaper versions of quasi-luxury woollens, priced above a floor set by the combination of transport and transaction costs, were often able to displace higher-priced competitors in these markets.

Furthermore, although similar shifts from cheaper to more luxury-oriented textile production can be documented elsewhere, and even in the Mediterranean basin itself -- particularly in Catalonia and especially in Italy -- this industrial phenomenon was not universal. ${ }^{64}$ Undoubtedly, some cheap textile industries

1964), pp. 237-48 Perroy; Wim Blockmans and Walter Prevenier, "Poverty in Flanders and Brabant from the Fourteenth to the Mid-Sixteenth Century: Sources and Problems," Acta Historiae Neerlandicae, 10 (1977), 20-57. For my own views on the Low Countries, see John Munro, "Economic Depression and the Arts in the Fifteenth-Century Low Countries," Renaissance and Reformation, 19 (1983), 235-50; reprinted in John Munro, Textiles, Towns, and Trade (1994); and Munro, "Patterns of Trade," pp. 148-65.

${ }^{63}$ See note 61 above.

${ }^{64}$ See Claude Carrère, Barcelone: centre économique à l'époque des difficultés, 1380 - 1462 (Paris, 1967), chapter 6: "La draperie barcelonaise," 423-528; Claude Carrere, "La draperie en Catalogne et en Aragon au XV $\mathrm{XV}^{\mathrm{e}}$ siècle," in Marco Spallanzani, ed., Produzione, commercio, e consumo dei panni di lana nei secoli XII-XVIII (Florence, 1976), pp. 475-510; Manuel Riu, "The Woollen Industry in Catalonia in the Later Middle Ages," in N.B. Harte and K.G. Ponting, eds., Cloth and Clothing in Medieval Europe: Essays in Memory of Professor E.M. Carus-Wilson, Pasold Studies in Textile History no. 2 (London, 1983), pp. 205-29, on the growth of quality-woolens industry in Catalonia, superseding the cheap-line cloth industries there; Hoshino, L'Arte della Lana in Firenze (1980) and "Rise of the Florentine Woollen Industry" (1983), pp. 184204, on the growth of the Florentine woollen industry, similarly superseding cheap, worsted-type production; Robert M. Lopez, "Market Expansion: The Case of Genoa," Journal of Economic History, 24 (1964), 44569; on Genoa and the shift to silks; and especially Maureen Mazzaoui, The Italian Cotton Industry in the Later Middle Ages, 1100 - 1600 (Madison, 1981), pp. 129-53, on the decline of the Italian cotton-fustian industry from the late 13th century. In England, the Norfolk worsted industry evidently peaked before the mid-14th century; see B. A. Holderness, "The Reception and Distribution of the New Draperies in England," Negley B. 
bordering on the Mediterranean survived on the basis of a major comparative advantage in transport and marketing costs; and though most were evidently established by the thirteenth century, some new entrants may have thrived as import-substitution industries to serve local markets precisely because of these rising transaction costs in long-distance trade. These economics of international comparative advantage in cheap textiles, therefore, may have eliminated most remaining holdouts in England and the Low Countries, except for a very few, such as Hondschoote and Arras, that could survive by serving local or regional markets. In fourteenth-century England some considerable exports of cheap, light worsteds, very similar to Flemish says, continued to be supported by sales in Baltic markets, at least until the 1360s; but they too radically declined from the 1370s, when such markets suffered afflictions similar to those that had plagued the Mediterranean from much earlier in the century. ${ }^{65}$

The English resurgence: rural factors in the rise of the English Broadcloth Trade from the 1350s?

When the English cloth-export trade recovered to regain and then dramatically to surpass its former

Harte, ed., The New Draperies in the Low Countries and England, 1300 - 1800 (Oxford, 1997), pp. 225-6. Cloth exports cannot be calculated before the imposition of the Cloth Custom in 1347; but thereafter, from the early 1350s, worsted exports fell from 23 percent of broadcloth exports to under 1 percent by the 1380s (14 worsteds per broadcloth, by relative export taxes), generally remaining at that low level for almost two centuries. Customs accounts, Public Record Office, KR, E. 101, and LTR, E. 356; also E.M. Carus-Wilson and Olive Coleman, England's Export Trade, 1275-1547 (Oxford, 1963), pp. 199-200.

${ }^{65}$ For some sporadic evidence of Mediterranean trade in cheap, light textiles, Lombard fustians and "Irish says" see John Day, ed., Les douanes de Gênes, 1376-1377, Ecole Pratique des Hautes Etudes, VIe section: Ports, Routes, Trafics, vol. XVII, 2 vols. (Paris, S.E.V.P.E.N., 1963), vol. I, pp. 353-54; Charles Verlinden, "Draps des Pays-Bas et du nord-ouest de l'Europe au Portugal au XV $\mathrm{X}^{\mathrm{e}}$ siècle," Annuario de estudios medievales, 3 (1966), pp. 240-8; Eliyahu Ashtor, "L'exportation de textiles occidentaux dans le Proche Orient musulman au bas moyen âge (1370 - 1517)," in Luigi de Rosa, et al., eds., Studi in memoria di Federigo Melis, Vol. II (Florence: G. Editore, 1978), pp. 349-50; Ashtor, Levant Trade, pp. 155-56; Baratier-Reynaud , Marseille, II, endpiece table, for 1380-82 only; Munro, "Industrial Transformations," pp. 111-19, 131-33; Munro, "Origins of the English 'New Draperies'," pp. 56-8, 68-71. For the Baltic, see Simonne AbrahamThisse, "Le commerce des draps de Flandre en Europe du Nord: Faut-il encore parler du déclin de la draperie flamande au bas moyen-âge?" in Marc Boone and Walter Prevenier, eds., La draperie ancienne des Pays Bas: débouchés et stratégies de survie (14e - 16e siècles)/ Drapery Production in the Late Medieval Low Countries: Markets and Strategies for Survival (14th-16th Centuries), Studies in Urban Social, Economic and Political History of the Medieval and Modern Low Countries (Leuven/Appeldorn, 1993), pp. 167-206; Terence H. Lloyd, England and the German Hanse, 1157 - 1611: A Study of Their Trade and Commercial Diplomacy (Cambridge, 1991), pp. 74-108; Childs, "English Export Trade," pp. 137-47; Munro, "Patterns of Trade," pp. 160-5; Munro, "Industrial Crisis" (forthcoming). 
importance, from the 1350s, it became more and more oriented to higher quality, more luxury-oriented woollens: and indeed, in almost mirror-image fashion, broadcloth exports soared while those of worsteds plunged, the latter virtually disappearing from the 1380s. Nevertheless English clothiers and merchants could not or did not seek to compete with the traditional Flemish and Brabantine urban draperies, nor with the newly expanding Florentine cloth industry, in the very uppermost echelons of the luxury markets. Instead, and indeed perhaps more wisely, they concentrated their efforts upon the lower-priced and thus much broader-ranged segment of the luxury or quality markets, with woollens that were from one half to one third the price of the better Flemish, Brabantine, and Florentine luxury woollens. Even so, with cloth exports in the range of $£ 2$ os 0d to $£ 210$ s $0 d$ sterling apiece ( 24 yds by $1.75 \mathrm{yds}$ ), such woollens were far from being cheap and vastly more expensive than worsteds; and in the later fourteenth century, such broadcloths would have cost an English master mason (Oxford-Cambridge, Exeter, Canterbury), then earning 5d - 6d per day, from 80 to 120 days' wages, the latter representing over half a year's full income. ${ }^{66}$

That English clothiers and cloth-export merchants were not then more ambitious and indeed not more successful in competing with their cross-Channel rivals in luxury cloth markets is all the more surprising in view of three major cost advantages, or supposed advantages, in producing high-quality woollens. For many historians, the two most important are the two that have just been discussed in the context of their rural location: (1) mechanical fulling, and (2) lower-wage labour from peasant craftsmen; and, as noted earlier, historians for the past century have assumed that this rejuvenated and rapidly expanding fourteenth-century English cloth industry had become essentially rural based, achieving its gains primarily from the more

${ }^{66}$ For cloth prices, see John Munro, "Industrial Protectionism in Medieval Flanders: Urban or National?" in Harry Miskimin, David Herlihy, and A. L. Udovitch, eds., The Medieval City (New Haven and London:, 1977), Table 13.5, pp. 226-7 [from P.R.O., E.122 series and E.356], reprinted in Munro, Textiles, Towns, and Trade; for wages, see John Munro, "Urban Wage Structures in Late-Medieval England and the Low Countries: Work-Time and Seasonal Wages," in Ian Blanchard, ed., Labour and Leisure in Historical Perspective, Thirteenth to Twentieth Centuries, Vierteljahrschrift für Sozial- und Wirtschaftsgeschichte Beiheft series no. 116 (Stuttgart, 1994), pp. 65-78; British Library of Political and Economic Science, Archives, Beveridge Collection boxes D3, F1, H10-11, P9-10; Phelps Brown and Hopkins, Perspective of Wages, pp. 1-11. 
advantageous economics of that rural location.

As the one major exception, Anthony Bridbury has instead credibly demonstrated that this 'new' cloth industry remained largely urban, until well into the later fifteenth century, when a variety of complex factors did combine to produce a somewhat more prominent shift to rural cloth-making. ${ }^{67}$ Curiously enough that later shift, such as it was, occurred at the very time or soon after Edward IV had subjected English cloth production, in town and village alike, to national and crown-supervised industrial regulations. ${ }^{68}$ For the later fourteenth century, when the English cloth export trade was rapidly expanding, the national aulnage accounts, recording taxes on manufactured woollens, provide firm evidence for the contention that well over half of those cloths produced for the market, and evidently an even greater share of the production destined for foreign markets, came from towns, large and small, rather than from villages. To be sure, Carus-Wilson herself had successfully cast doubts on the validity of the late fifteenth-century aulnage accounts (perhaps to quash any notion of any remaining urban vitality in cloth production), ${ }^{69}$ but Bridbury and, before him, H.L. Gray, do provide good grounds for the credibility of the earlier accounts and for the belief that the locations named were those where

${ }^{67}$ See: A.R. Bridbury, Economic Growth: England in the Later Middle Ages (London, 1962), pp. 5282; A.R. Bridbury, Medieval English Clothmaking: An Economic Survey (London, 1982), pp. 27-36, 62-85 . For further evidence, see Bartlett, "Decline of York," pp. 17-331; Heather Swanson, "The Illusion of Economic Structure: Craft Guilds in Late Medieval English Towns," Past \& Present, no. 121 (November 1988), pp. 29 - 48; Heather Swanson, Medieval Artisans: An Urban Class in Late Medieval England (Oxford, 1989), pp. 26-44; Derek J. Keene, Survey of Medieval Winchester, Winchester Studies no. 2, 2 vols. (Oxford, 1985), I, pp. 299-316; Derek Keene, “Textile Manufacture: The Textile Industry," in Martin Biddle, ed., Object and Economy in Medieval Winchester, Winchester Studies, vol. 7.ii (Oxford, 1990), pp. 200-40; Derek Keene, "Textile Terms and Occupations in Medieval Winchester," Ler História, 30 (1996), 135-47. See below, pp. for York's decline; and also n. 70.

${ }^{68}$ Great Britain, Record Commission, Publications no. 8, Statutes of the Realm, 11 vols. II (London, 1836), pp. 403-07: statute 4 Edward IV c. 1 (1464-65): “every whole Woollen Cloth, called Broad Cloth", after fulling and tentering, to 24 yards long by 2 yards, or at least 7 quarter yards within the lists, "and to every Yard an Inch" [i.e. 37 in. per yd].

${ }^{69}$ Eleanora M. Carus-Wilson, "The Aulnage Accounts: A Criticism," Economic History Review, 1st ser., 2 (1929), reprinted in her Medieval Merchant Venturers, pp. 279-91. 
the cloth was actually produced, rather than taxed and sold. ${ }^{70}$ Furthermore, there is much abundant evidence for the impressive importance of both new and older urban centres in cloth production. In the West Country itself, certainly Bristol, Salisbury, Gloucester, Worcester, Exeter became famous as leading urban clothmanufacturing centres.

Of equally great importance is the evidence that virtually all of these West Country and West Midlands cloth towns used fulling-mills, if not necessarily within the town, certainly close by the town, without any interference from resident fullers and their guilds. ${ }^{71}$ They were not alone. The next most important clothproducing region in later-medieval England, and one whose importance was unfairly ignored by Carus-Wilson, was East Anglia, which contained several towns, such as Colchester, that had earlier achieved importance as textile exporters, during the thirteenth century, and revived in importance, along with many other new towns during the fourteenth and early fifteenth centuries, in particular numerous small towns, but towns nevertheless, or near the Colne and Stour rivers, the latter forming the boundary between Suffolk and Essex. Many and perhaps most of them also used fulling mills, powered by these same rivers, slow-moving though they were; and again these mills were located either in or more commonly just outside the town walls. ${ }^{72}$ With its many

${ }^{70}$ H.L. Gray, "The Production and Exportation of English Woollens in the Fourteenth Century," English Historical Review, 39 (1924), 13-55. For Bridbury, see n. 66 above.

${ }_{71}$ For Bristol, fullers' ordinances in Francis Bickley, ed., The Little Red Book of Bristol (Bristol, 1900), II, pp. 10-12 (1346), pp. 15-16 (1381), pp. 75-79 (1406); for Salisbury (W iltshire) and Gloucester, see George Ramsay, The Wiltshire Woollen Industry in the Sixteenth and Seventeenth Centuries, 2nd edn. (London, 1965), pp. 18-20; for Worcester, Statutes of the Realm, III, pp. 459-60: 25 Hen VIII c. 18, 1533-34. Exeter is the only one in this list for which fulling-mills have not yet been documented but for its cloth industry, see Maryanne Kowaleski, Local Markets and Regional Trade in Medieval Exeter (Cambridge and New York, 1995). See also Kenneth Ponting, A History of the West of England Cloth Industry (London, 1957); Kenneth G. Ponting, The Woollen Industry of South-West England: An Industrial, Economic, and Technical Survey (Bath and New York, 1971).

${ }^{72}$ For a verification of the location of fulling-mills in Suffolk and Essex, especially the small towns, see the map published in Pelham, Fulling Mills, which shows 11 such mills (and 2 more in Norfolk). See nn. 72-6 below. See for the cloth industry in East A nglia, Richard Britnell, Growth and D ecline in Colchester, 1300 - 1525 (Cambridge, 1986), pp. 13-21, 76-78; M ichael Gervers, "The Textile Industry in Essex in the L ate 12th and 13th Centuries," Essex Archaeology and History: The Transactions of the Essex Society for Archaeology and History, 3rd ser., 20 (1989), pp. 48-49, 69. 
draperies, in both villages and towns, East Anglia and adjacent Norfolk was a region certainly far more prominent than the West Riding of Yorkshire, let alone the industrially marginal Lake District, to which CarusWilson gave much greater significance, evidently because they appear to have been more distinctly rural as water-powered textile producers in the later Middle Ages. ${ }^{73}$

Furthermore, in eastern lowland and southern England, apart from East Anglia, several of the older traditional cloth towns that had supposedly 'expired' during the late thirteenth century 'urban industrial crisis' subsequently managed to regain an important if lesser role in fourteenth-century English cloth-manufacturing: in particular, York, Winchester, London, Lincoln, and Leicester. ${ }^{74}$ In so doing, the drapers or clothiers of most of these older cloth towns also resorted to fulling-mills, chiefly in adjacent rural sites. ${ }^{75}$ To be sure, Lincoln,

${ }^{73}$ See Heaton, Yorkshire Woollen Industry, pp. 18-88; and the sources cited above in nn.

${ }^{74}$ Heaton, Yorkshire Woollen Industries, pp. 18-88; Swanson, "Craft Guilds," pp. 29 - 48; Swanson, Medieval Artisans, pp. 26-44; Bartlett, "Expansion and Decline of York,” pp. 17 - 33; Maud Sellers, "The Textile Industries," in William Page, ed., The Victoria History of the Counties of England: A History of the County of York, 3 vols. (London, 1907 - 1913), Vol. II (1912), pp. 406 - 29.

75 See n. 73, and for York; York ordinances, permitting fulling just outside the town, see Maude Sellers, ed., York Memorandum Book, 2 vols., Surtees Society nos. cxx and cxxv (London, 1911-14), I, pp. 70-2: ordinacio fullaris (c.1390); but see also Vol. II, pp. 206-07, for an ordinance of 5 March 1464, which the town government, seeking to alleviate the recent decline of the urban cloth industry, issed to prohibit anyone within the franchise of York to deliver cloths for fulling to "any foreyn walker [fuller] to full or to wirk," with no mention of mills. See also Swanson, Medieval Artisans, pp. 41-42 (though emphasising rural advantages for fulling). For Lincoln, see an ordinance issued between 1297 and 1337 requiring fulling-stocks rather than vats, in L.T. Smith, ed., English Gilds: Orgininal Ordinances of the Fourteenth and Fifteenth Centuries, Early English Text Society no. 40 (London, 1870), pp. 179-80. For London, see the 1298 ordinance concerning fulling mills outside the city: a ban limited only to fullers, weavers, dyers, but not drapers, last referred to in 1314; drapers were clearly permitted to full their own cloths in Stratford mills; subsequent bans were issued only for fulling hats and caps at the mills. See Riley, Liber Custumarum, I, pp. 127-9 (1298): "ne face porter, mener, ne bailler, hors de la cite nul drap pur foller as molins, fors ceux memes a qui les draps serront, et les queus draps il voillent pur lour avower." (26 Edward I).; Reginald Sharpe, ed., Calendar of Letter-Books of the City of London at the Guildhall (London, 1899-1912): Letter Book C, pp. 51-2 (1298); pp. $52-53$ (1314); Letter Book D, pp. 239-40 (1311). In July 1362, the London civic government issued an ordinance for the "mistery of Hurers" to require that all caps, hats, and bonnetts be fulled and felted by hand only; and on 2 August and 17 September 1376 the Mayor and Aldermen of London forbade any Hurer to full their caps at any water-powered fulling mills -- and specifically "in the mills of Wandleswroth, Oldeford, Stratford, and Enefeld, where the Fullers full their cloths." Letter Book H, pp. 362 (July 1362), 37 (Aug. 1376) , 47-48 (Sept. 1376); see also Letter Book K, p. 220 for the Hurers' petition to have this ordinance properly enforced, on 20 Nov. 1437. In 1482-83, Parliament enacted a statute prohibiting anyone in England from fulling hats, bonnets, and caps "in fulling mills," for "in the said mills the said huers [hats] and caps be 
Leicester, and the other traditional eastern seaboard industrial towns never did regain their former prominence in export-oriented cloth production. York, however, did come close, before finally declining in the later fifteenth century: first, with the loss of Baltic markets, the decay of the ports of Hull, Boston, and Lynn, and the consequent deterioration in the mercantile fortunes that had helped finance York's industry; and secondly, with the rapid expansion of London and its Antwerp-based cloth merchants, who, in seeking more woollens, began financing cloth production in neighbouring Yorkshire towns. ${ }^{76}$

The same was true of the southern city of Winchester (Hampshire), which, from the mid-fourteenth century, certainly recovered some of its former stature as an export-producer, before also declining in the mid fifteenth century. As this town's eminent historian Derek Keene has demonstrated, the bishop of Winchester built a new fulling mill in the 1360s, at Prior's Barton, just outside the city, adjacent to a long established civic fulling mill (dating from the 1220s), which produced revenues that more than doubled between 1370 and 1400. In 1402, Winchester's town government built an additional fulling mill; and in 1406, the bishop farmed the Prior's Barton mill to a Winchester entrepreneur, who, sometime before 1422, converted an episcopal watermill, at Durn's Gate, into yet another fulling mill. ${ }^{77}$ As should be self-evident, with no evidence for any compulsion employed in the use of these mills, they would not have attracted capital investment for their construction, elicited continuous business from the civic fullers and drapers, and increased their mill-revenues, unless they had provided substantial cost-savings over traditional foot-fulling. ${ }^{78}$ Indeed, the urban fullers of

broken and deceitfully wrought and in no wise by the mean of any Mill may be faithfully made." But such bans were never applied to woollen cloths. Statutes of the Realm, II, pp. 473-74: 22 Edwardi IV c. 5. For an alternative view of some of these bans, see Carus-Wilson, "Industrial Revolution," pp. 194-209; Carus-Wilson, "Woollen Industry," pp. 667-73.

${ }^{76}$ See Swanson, Medieval Artisans, pp. 26-52; Swanson, "Craft Guilds," pp. 29-48; Heaton, Yorkshire Woollen Industry, pp. 45-88.

${ }^{77}$ Keene, Survey of Medieval Winchster, I, pp. 304-07; II, no. 972, pp. 1050-2; no. 1057, pp. 1082-3; Keene, "Textile Manufacture," pp. 208-10; Keene, "Textile Terms," pp. 140-1. Fulling mill revenues had risen from $£ 73 s$. $0 d$. in 1370-71 to $£ 160$ s. $0 d$. in 1400-01.

${ }^{78}$ See above, pp. and nn. ; and below, pp. 31-2, and Munro, "Industrial Entrepreneurship," pp. 377-88. 
Winchester came to own, lease, and operate some of the four town-sponsored fulling mills, which, in Keene's view, 'strengthened the urban industry rather than promoting its migration into the countryside'. ${ }^{79}$

In sum, therefore, the contention that a rural location, offering both cheap labour and cheap water power, along with 'industrial freedom', was the primary factor responsible for the remarkable resurgence of the English cloth industry from the mid fourteenth century and for its ultimate victory over its urban-based continental rivals by the later fifteenth century is unfounded. First and foremost, low wages do not necessarily mean lower cost labour, even if the actual wage differentials betwen town and countryside could be measured. If economists are justified in believing that the market wage rate is determined by the marginal revenue product (MRP) of labour, one might well suspect that labour productivity was indeed lower in the countryside, especially when so many of the textile workers were evidently not specialised craftsmen but part time workers in both industry and agriculture. Furthermore most worked at home unsupervised, some perhaps in nucleated villages in mixed farming regions, but others, in more pastoral regions, in scattered houses, so that production was all the more difficult to monitor. That monitoring problem explains, of course, why virtually all textile wages were paid by the piece rather than by the day (the latter prevailing in the construction trades).

Such rural industrial productivity problems involving lower, or potentially lower, levels of training, skill, and specialisation, and the attendant problems of monitoring, may have been less significant, however, for the preliminary stages of cloth production, even if they did account for perhaps 50 percent of pre-finishing labour costs: i.e. wool-beating, sorting, cleansing, and greasing; combing (warps) and carding (wefts), and spinning the two types of yarn (by drop-spindle and the wheel, respectively). ${ }^{80}$ Yet, if we were able to prove

${ }^{79}$ Keene, “Textile Terms," p. 141 (quotation); Keene, Survey of Medieval Winchester, I, pp. 302-09; II, pp. 1050-52 (doc. no. 972), pp. 1082-83 (doc. no. 1057); Keene, “Textile Manufacture,” pp. 208-12.

${ }^{80}$ See Miller, "English Textile Industry," pp. 72-4; Miller and Hatcher, Medieval England, pp. 93-8; Munro, “Textile Technology," pp. 693-715; Walter Endrei, L'evolution des techniques du filage et du tissage: du moyen âge à la revolution industrielle (The Hague, 1968), pp. 49-135; Walter Endrei, "La productivité et la technique dans l'industrie textile du XIIIe au XVIIIe siècle," in Sara Mariotti, ed., Produttività e tecnologie nei secoli XII-XVII (Florence, 1981), 253-62; Walter Endrei, "Manufacturing a Piece of Woollen Cloth in Medieval Flanders: How Many Work Hours?" in Erik Aerts and John Munro, ed., Textiles of the Low Countries in European Economic History (Leuven,1990), pp. 14-23; De Roover, "Florentine Firm," pp. 3-33. 
that in England, the Low Countries, Italy, and elsewhere that economic advantages were derived from having these preliminary tasks performed in the countryside, and especially in having dependent female labour perform almost all of them, such advantages would not necessarily have led to rural locations for cloth-manufacturing per se; for there is some evidence that many urban textile industries in all three of these regions, even in their medieval heyday, had acquired their yarns from the adjacent countryside. ${ }^{81}$ Urban cloth-making thus principally meant the much more specialised and male-dominated crafts of weaving, fulling, dyeing, shearing, and ancillary finishing processes, which were the only ones to be guild organized. The advantages of performing these textile crafts in towns must be considered later, after examining the structure and performance of the traditional urban draperies of the later medieval Low Countries; and in particular the role of fulling and fullers' guilds in these draperies.

For the moment, the presumed rural advantages for mechanical fulling, in cheaper power and lower opportunity costs, may be deemed to be soundly based in economic theory; but even so, as the English evidence has also indicated, urban clothiers were not precluded from using fulling-mills in the adjacent countryside. The advantages of mechanical fulling themselves will also be subjected to a further reconsideration in examining the structures and changing fortunes of the urban draperies in the later medieval Low Countries.

\section{The role of taxation and fiscal policies in the rise of the English broadcloth trade, 1336-1429}

There remains, however, a third, final, and indeed quite powerful explanation for the rise and ultimate victory of the English cloth trade over most of its continental rivals: a far lower tax or fiscal burden on wools, as the key ingredient and indeed determinant of luxury-quality woollens. The relative changes in those fiscal burdens, involving both taxes and various bullionist impositions, in affecting the fortunes of cloth

${ }^{81}$ See evidence for the urban use of rural spun-yarns in Georges Espinas and Henri Pirenne, eds., Recueil de documents relatifs à l'histoire de l'industrie drapière en Flandre: Ire partie: des origines à l'époque bourguignonne, 4 vols., Commission Royale d'Histoire (Brussels, 1906-1920); Nicolaas Posthumus, ed., Bronnen tot de geschiedenis van de leidsche textielnijverheid, 1333-1795, 3 vols. (The Hague, 19101922).

George Espinas, ed., Documents relatifs à la draperie de Valenciennes au moyen âge (Paris, 1931); Henri De Sagher, et al., eds., Recueil de documents relatifs à l'histoire de l'industrie drapière en Flandre, IIe partie: le sud-ouest de la Flandre depuis l'époque bourguignonne, 3 vols. (Brussels, 1951-66). 
manufacturers on both sides of the Channel, took place during and over four distinct periods, thus explaining in part, and only in part, why the English victory took so long to be achieved: the 1330s, the 1360s, the 1390s, the 1430s, and the 1460s. In essence, the English crown rightly looked upon the wool-export trade as by far the easiest and by far the most lucrative source of tax revenues and especially of ready cash. For medieval England produced in vast abundance by far the world's best wools, with very curly, extremely fine, shortstapled fibres that had excellent felting qualities when fulled; and that superlative reputation for fineness did not encounter any serious challenge until the mid-sixteenth century, when Spanish merino wools, whose production evidently had begun only from the 1340s, finally achieved superior qualities, through some combinations of cross-breedings and changes in flock management. ${ }^{82}$ Evidently the English crown perceived a foreign demand for at least the finer English wools that was or became relatively inelastic. Certainly once the cloth industries of the Low Countries and also of Italy, Florence especially, reoriented their textile production, from the 1330s, more and more towards luxury woollens production, they thereby became exclusively dependent upon those finer English wools, at least for their export trades. When Edward I levied the first export duty, as the Old Custom of 1275 , those continental cloth industries were by no means so fully dependent on English wools; and that initial rate was quite modest, at 6s 8d per woolsack (of $364 \mathrm{lb}$.), perhaps about 7 percent of the current mean export value..$^{83}$

82 From the Welsh Marches of Shropshire and Herefordshire, the Cotswolds -- adjacent Gloucestershire, Oxfordshire, Worcester -- and thirdly, Lincolnshire. See John Munro, "Wool-Price Schedules and the Qualities of English Wools in the Later Middle Ages, ca. 1270 - 1499," Textile History, 9 (1978), 118-69; reprinted in John Munro, Textiles, Towns, and Trade; Michael Ryder, "British Medieval Sheep and Their Wool Types," in D. W. Crossley, ed., Medieval Industry (London, 1981), pp. 16-28. For Spanish wools, see Robert Lopez, "The Origin of the Merino Sheep," The Joshua Starr Memorial Volume: Studies in History and Philology (a publication of Jewish Social Studies no. 5, New York, 1953), 161-68; C.R. Phillips and W.D. Phillips, Spain's Golden Fleece: Wool Production and the Wool Trade from the Middle Ages to the Nineteenth Century (Baltimore-London, 1997), pp. 40-2, 343; Munro, "Origins of the English 'New Draperies,," pp. 45-50. For Spanish wools of Roman Andalusia-Extramadura (Baetica), and their postRoman disappearance, see A. T. Fear, "The Golden Sheep of Roman Andalusia," Agricultural History Review, 40:ii (1992), 151 - 5.

${ }^{83}$ Carus-Wilson and Coleman, England's Export Trade, pp. 194-96. Wool export duties were temporarily increased by Edward I's maltote in 1294-97, to 462 8d per sack, to help finance his war with France. By his Carta Mercatoria of 1303, alien merchants had to pay an additional New Custom of 3s $4 \mathrm{~d}$ per 
That tax structure was abruptly and brutally altered in 1336, on the very eve of the Hundred Years' War, and just when the Flemish cloth industry was undergoing those previously discussed industrial transformations. Edward III and his specially convened 'Great Council' imposed an additional 'subsidy, of 20s 0d a sack, which he increased to 33s 4d per sack in March 1338 and to 40s 0d a sack in November 1341, for a total tax burden of $46 \mathrm{~s} 8 \mathrm{~d}$ per sack (50s 0d a sack for aliens) ${ }^{84}$ Subsequent merchant assemblies and parliaments periodically confirmed that high rate up until 1362, when the subsidy was temporarily halved; but the following year, Edward III made the recently conquered French port of Calais the official and compulsory wool staple for all wool exports to northern Europe, governed by a mercantile cartel that was designed to pass this tax incidence more fully on to foreign buyers (i.e. rather than on to the domestic wool-growers), in part by fixing uniform minimum wool prices for each county. That same year Parliament restored the wool subsidy to 40 s per sack; and then, in 1369 , increased it to $43 \mathrm{~s} 4 \mathrm{~d}$ per sack, for a total duty on native exporters of $50 \mathrm{~s}$ Od a sack (51s 7d with an added Calais 'import' duty).

Arguably, however, for a variety of reasons, the Calais Staple did not become a fully effective cartel in achieving this goal of transmitting the tax burden until the 1390s. ${ }^{85}$ By this time, the real burden of the wool-export duties, which were specific rather than ad valorem, and thus levied as a fixed amount per sack, had increased substantially because of the stark deflation that had beset northwestern Europe from the late

sack. For contemporary wool prices, see T.H. Lloyd, The Movement of Wool Prices in Medieval England (Economic History Review supplement no. 6, 1973), pp. 38-41.

${ }^{84}$ F.R. Barnes, "The Taxation of Wool,1327-48,"and George Unwin, "he Estate of the Merchants, 1336-1365," in George Unwin, ed., Finance and Trade under Edward III ( London, 1918), pp. 143-6, 179-97; Terence Lloyd, The English Wool Trade in the Middle Ages (Cambridge, 1977), pp. 144-7, 193-224; W.M. Ormrod, "The Crown and the English Economy, 1290-1348," in Bruce Campbell, ed., Before the Black Death: Studies in the 'Crisis' of the Early Fourteenth Century (Manchester, 1991), pp. 167-75; Munro, 'Industrial Entrepreneurship', pp. 377-88; and n. 83-4 below.

${ }^{85}$ For the foregoing see Lloyd, Wool Trade, pp. 193-224; Munro, "Wool Price Schedules," pp. 13543; Munro, "Industrial Entrepreneurship," pp. 377-88; Munro, "Industrial Crisis," pp. During this period, the crown often undermined their monopoly powers: by allowing Italian and Spanish merchants to bypass the Staple in exporting wools directly by sea to the Mediterranean (1378); by granting other exemptions to ship wools directly to Middelburg and Dordrecht; by selling export licences; and by periodically removing the Staple from Calais (intermittently in 1369-76, in 1382-88, and 1390-92). 
1370 s, bringing with it a fall in nominal wool prices. As a consequence, the wool export taxes now amounted to virtually 50 percent of the mean export prices of the better grades of English wools; and, according to records of the Flemish, Dutch, and Brabantine urban draperies for the early fifteenth century, these taxburdened English wools were accounting for about 70 percent of their pre-finishing manufacturing costs. ${ }^{86}$ English clothiers, however, bore no such burdens, for they were able to buy the very same high quality wools totally free of taxes; and when woven and fulled into broadcloths, their cloth exports were subjected to a very minor duty of $14 \mathrm{~d}$ per broadcloth by denizen merchants (and only from 1347) and 12d by Hanseatic merchants, a specific tax that remained unchanged until 1558; and in the late fourteenth, early fifteenth century it amounted to no more than 2 to 3 percent of the mean value of exported woollens. ${ }^{87}$ In sum, we may reckon from all these tax calculations that English fiscal policies had unintentionally but effectively given the native cloth industry a major cost advantage of about 25 to 30 per cent, in producing medium-quality cloths.

Some economic consequences of these English fiscal and Staple policies can be readily seen in the export and continental production statistics for the second half of the fourteenth century, expressed in decennial

${ }^{86}$ For evidence on wool duties, wool prices, cloth production costs, and the price level, see: Lloyd, Wool Prices, pp. 41-5; John Munro, "Industrial Protectionism in Medieval Flanders: Urban or National?" in Harry Miskimin, David Herlihy, and A. L. Udovitch, eds., The Medieval City (New Haven and London: Yale University Press, 1977), Tables 13.1-3, pp. 254-6; John Munro, "The Medieval Scarlet and the Economics of Sartorial Splendour," in N. B. Harte and K. G. Ponting, eds., Cloth and Clothing in Medieval Europe: Essays in Memory of Professor E. M. Carus-Wilson, Pasold Studies in Textile History No. 2 (London, 1983), Table 3.1, p. 32; Table 3.12, p. 52; both reprinted in John Munro, Textiles, Towns, and Trade; John Munro, "Mint Outputs, Money, and Prices in Late-Medieval England and the Low Countries," in Eddy Van Cauwenberghe and Franz Irsigler, eds., Münzprägung, Geldumlauf und Wechselkurse/ Minting, Monetary Circulation and Exchange Rates, Trierer Historische Forschungen, Vol. 7: Akten des 8th International Economic History Congress, Section C-7, Budapest 1982 (Trier, 1984), pp. 31-122.

${ }^{87}$ See Carus-Wilson and Coleman, England's Export Trade, pp. 194-98; Norman S.B. Gras, The Early English Customs System: A Documentary Study of the Institutional and Economic History of the Customs from the Thirteenth to the Sixteenth Century, Harvard Economic Studies vol. xviii (Cambridge, Mass. 1918), pp. 59-84; Munro, "Industrial Protectionism," Tables Tables 13.3-5, pp.265-66 [for cloth prices]; John Munro, 'Anglo-Flemish Competition in the International Cloth Trade, 1340 - 1520', in JeanMarie Cauchies, ed., L'Angleterre et les pays bourguignons: relations et comparaisons, XVe-XVIe siècle: annual issue of Centre européen d'études bourguignons, no. 35 (1995), 37-60. Other alien merchants, however, had to pay an export duty $2 \mathrm{~s} 9 \mathrm{~d}$ per broadcloth, and subsequently also an ad valorem poundage tax of 5\%, which the Hanse refused to pay. Not surprisingly, English and Hanse merchants together soon gained the lion's share of the cloth trade; See Carus-Wilson and Coleman, England's Export Trade, pp. 75-119. 
means. Wool exports, having achieved a mid-century peak of 31,504 sacks in 1350-9, declined only slightly by the next decade, to a mean of 29,893 sacks (down 5.1 per cent); but then between 1360-9 -- with the imposition of the Calais Staple and higher export duties -- and 1390-9, wool exports fell by 38 per cent, to a mean of 18,546 sacks; and a corresponding fall in production indices for some of the Flemish and Brabantine urban draperies can also be seen in Table 1. Meanwhile, broadcloth exports soared from a mean of just 4,426 pieces in $1350-9$ to a peak of 38,469 pieces in $1390-9$, a rise of 769 per cent. Over this same period, total English exports, measured by combining woolsacks and broadcloths at 4.33 cloths per sack, experienced an overall decline of 16 per cent, much less than the aggregate fall in European population, providing another indication of the inroads that the English cloth trade was making into the markets of its overseas competitors, by the end of the fourteenth century. ${ }^{88}$

\section{Changes in the Flemish-Brabantine urban cloth industries during the diastrous fourteenth century}

That the urban cloth industries of the southern Low Countries were still managing to survive in the 1390s is all the more amazing when one recites the full litany of disasters that had befallen them in the full century since the 1290s: the loss of their Mediterranean markets for cheap and light textiles, probably the largest segment of their industrial production; the impact of widespread chronic warfare and war related activities in disrupting, or contracting markets, and in raising transacton costs in servicing those markets, for the better quality-lines of textiles on which these industries refocused; the rise of the competitive quasi-rural nouvelles draperies within the southern Low Countries; the expansion of a rejunevated and new English cloth trade; and the related impact of tax and other fiscal measures on the English wool trade, on which the Low Countries' draperies had become so dangerously dependent; the Black Death and subsequent drastic

${ }^{88}$ For analyses of these phenomena and the data in table 1, see Munro, "Industrial Protectionism," pp. 229-68; Munro, "Anglo-Flemish Competition," pp. 37-60; John Munro, "Monetary Contraction and Industrial Change in the Late-Medieval Low Countries, 1335 - 1500," in Nicholas Mayhew, ed., Coinage in the Low Countries, 880 - 1500: The Third Oxford Symposium on Coinage and Monetary History, British Archeological Reports, International Series No. 54 (Oxford: Ashmolean Museum, 1979), pp. 95-161; John Munro, "Economic Depression and the Arts in the Fifteenth-Century Low Countries," Renaissance and Reformation, 19 (1983), 235-50; reprinted in John Munro, Textiles, Towns, and Trade; Lloyd, Wool Trade, pp.193-255; and sources cited above in nn. 
depopulations, which, along with the military strife of the Hundred Years' War era, dramatically reduced their remaining markets; and, finally, the often terribbly disruptive impact of guild strife, especially between weavers and fullers, within the Flemish urban cloth industries especially.

For Flemish textile production, certainly by far the most destructive manifestation of that guild strife, though by no means the exclusive element within it, was the Ghent-led civil war, or the so-called Second Artevelde Rebellion, of 1379-85, which also involved both English and French military intervention; and even the crushing Burgundian-French victory at West Roosebeke in November 1382 did not bring peace for another three years. Nor did Ghent's submission and the truce of December 1385 permit any real recovery, for the German Hanse towns, led by its Baltic members, after failing to gain reparations for war damages, imposed a trade embargo on Flanders, from 1388 to 1392 . Taking very quick and strategic advantages of these Flemish difficulties were both English and Dutch cloth merchants, the latter in particular promoting exports from the recently established Leiden cloth industry, to invade and capture important Baltic markets; and the English successes are clearly reflected in the sharp rise in the export statistics. Yet the English, and to a lesser extent, the Dutch became involved in their own conflicts with the Baltic Hanse; and as a result, English cloth exports to the Baltic, having peaked around 1402, then experienced an irredeemable decline in this region, an important factor that subsequently encouraged the London-based Merchants Adventurers to seek a new continental outlet for English woollens ${ }^{89}$. In 1420, they established their permanent overseas headquarters at Antwerp, the one major Low Countries' port town that no longer had a cloth industry to protect and one that came to welcome

89 On these events, see Lloyd, England and the German Hanse, pp. 50-109; Nicholas, Medieval Flanders, pp. 227-31,242-6, 318-22; Richard Vaughan, Philip the Bold: The Formation of the Burgundian State (London, 1962), pp. 16-38, 168-97; Michael Postan, "Economic and Political Relations of England and the Hanse from 1400 to 1475," in Eileen Power and Michael Postan, eds., Studies in English Trade in the Fifteenth Century (London, 1933), pp. 91-104; republished in Michael Postan, Medieval Trade and Finance (Cambridge and New York, 1973), pp. 232 - 304; Marian Malowist, "L'expansion économique des Hollandais dans le bassin de la Baltique aux XIVe et XVe siècles," Studia z dziejow rzemiosla w okresie kryzysu feudalizmu w Europie Zachodniej w XIV i XV wieku (Warsaw, 1954); republished in his Croissance et regression en Europe, XIVe - XVIIe siècles (Paris: 1972), pp. 91-138; Dick E.H. De Boer, Graaf en Grafiek: sociale en economische ontwikkelingen in het middeleeuwse "Noordholland" tussen 1345 en 1415 (Leiden, 1978), pp. 211-32; Blockmans, "The Economic Expansion of Holland and Zeeland," pp. 41-58. 
a subsequent flood of English woollens..$^{90}$

For the first two decades of the fifteenth century, however, the cloth industries of the southern Low Countries had managed to stage an evident comeback, with some semblance of an 'Indian Summer' of prosperity, though one necessarily based on far smaller and much narrower European markets than these industries had enjoyed a century and more earlier. According Hektor Amman, in an exhaustive study of earlyfifteenth-century German and other Central European markets, Flemish woollens, especially including those of the drie steden, had regained their former pre-eminence, followed by the Brabantine and then Dutch woollens, while the much cheaper English broadcloths now or still ranked a very distant fourth. ${ }^{91}$ A more recent study by Abraham-Thisse largely supports that view on cloth markets, though her much narrower range of sources indicated a relatively greater prominence in Baltic markets for medium-priced Flemish and Artesian textiles. ${ }^{92}$ In the early fifteenth century Mediterranean markets, the Florentine and other Italian luxury woollens (from various towns in Tuscany and Lombardy), had gained clear ascendancy, at the direct expense of those from the Flemish drie steden and major Brabantine towns; but many of the smaller-town nouvelles draperies, especially those of Wervik, Kortrijk, Comen, and Menen, were more than holding their own in selling very good quality and quite high priced heavy-weight woollens, though they would soon face a new challenge from Catalan cloth producers evidently using now better quality merino wools (as were some Italian draperies). ${ }^{93}$

90 See sources in n. 87, and: J.A. Van Houtte, "La genèse du grande marché international d'Anvers à la fin du moyen âge," Revue belge de philologie et d'histoire, 19 (1940), 87-126; J.A. Van Houtte, "Bruges et Anvers: marchés 'nationaux' ou 'internationaux' du XIVe au XVIe siècle?" Revue du Nord, 24 (1952), 89108; Van der Wee, Antwerp Market, II, pp. 18-49; E. M. Carus-Wilson, "The Origins and Early Development ofthe Merchant Adventurers' Organization of London," Economic History Review, 1st ser., 4 (1933), reprinted in her Medieval Merchant Venturers, pp. 143-82; Munro, "Patterns of Trade," pp. 160-68.

${ }^{91}$ Hektor Ammann, "Deutschland und die Tuchindustrie Nordwesteuropas im Mittelälter," Hansisches Geschichtsblätter, 72 (1954), 1-63.

${ }_{92}$ Thisse, “Draps de Flandre,” pp. 167-206.

${ }^{93}$ Federigo Melis, "Uno sguardo al mercato dei panni di lana a Pisa nella seconda metà del trecento," Economia e storia, 6:1 (March 1959), 321-65; Federigo Melis, "La diffusione nel Mediterraneo occidentale dei panni di Wervicq e delle altre citta della Lys attorna al 1400," in Studi in onore di Amintore Fanfani, Vol. III: Medioevo (Milan, 1962), pp. 219-43; Eliyahu Ashtor, "L'exportation de textiles occidentaux dans le Proche 
But again, as in the Baltic, sales of English broadcloths still fared badly (along with a very few cheap worsteds and 'straits'); and indeed the English cloth trade would not succeed in making major gains in the Mediterranean basin, despite all its reputed advantages, until much later in the fifteenth century, and especially after the formerly prominent Flemish nouvelles draperies of Wervik, Kortrijk, and Comen were themselves suffering a severe industrial and commercial decline, along with the traditional urban draperies of Bruges, Ypres, Ghent (i.e. the Flemish drie steden), Brussels, Mechelen, and Leuven. ${ }^{94}$

\section{Urban institutions and the survival of the Low Countries' draperies: fulling and the fullers' guilds}

Since the ultimate decline of the traditional urban draperies in the southern Low Countries is indisputable, since the evidence of cost advantages of mechanical fulling is compelling, and since fulling was a crucial produce in the manufacture of genuine heavy-weight woollens, now the predominant form of textile manufacturing, the absence, or supposed absence, of fulling-mills in the traditional urban cloth industries of the medieval Low Countries must be re-examined. This question is all the more important in the light of relatively recent evidence that demonstrates the widespread and evidently effective use of fulling mills in many of the so-called nouvelles draperies -- not those just listed above -- and other cloth industries of sixteenthcentury Flanders, Brabant, and the bishopric of Liège (Vesdre region). Must we therefore conclude that in the southern Low Countries urban guilds and the governments that supported them are to be faulted for preventing

Orient musulman au bas moyen âge (1370 - 1517)," in Luigi de Rosa, et al., eds., Studi in memoria di Federigo Melis, Vol. II (Florence, 1978), pp. 303 - 77; Eliyahu Ashtor, "Catalan Cloth on the Late Medieval Mediterranean Markets," Journal of European Economic History, 17 (Fall 1988), 227-57; Hoshino, "Rise of the Florentine Woollen Industry," pp. 84-204; Hidetoshi Hoshino and Maureen Mazzaoui, "Ottoman Markets for Florentine Woolen Cloth in the Late Fifteenth Century," International Journal of Turkish Studies, 3 (198586), pp. 17-31; Munro, "Origins of the English 'New Draperies'," pp. 66-71; Munro, "Patterns of Trade," pp. 157-60.

${ }^{94}$ See n. 91 above, n. below; and also: E. B. Fryde, "Anglo-Italian Commerce in the Fifteenth Century: Some Evidence about Profits and the Balance of Trade," Revue belge de philologie et d'histoire, 50 (1972), 345-55; E. B. Fryde, "Italian Maritime Trade with Medieval England (ca. 1270 - c. 1530), Recueils de la société Jean Bodin, 32 (1974), 291 - 337, both reprinted in his Studies in Medieval Trade and Finance (London, 1983). 
such mechanization and thus industrial innovations in general? $?^{95}$

Carus-Wilson, in championing her 'industrial revolution’ thesis to explain the ultimate English victory in the international cloth trade, necessarily had to consider this particular question, to which she supplied two answers. The first now seems to be clearly wrong: that 'Flanders like Lincolnshire is a land of windmills, not water-mills'.$^{96}$ On the contrary, watermills proliferated throughout medieval Flanders, and indeed throughout all of the southern Low Countries. Furthermore, as Van Uytven has clearly demonstrated, fulling-mills themselves can be found in several small-town draperies in the southern Low Countries during the thirteenth and early fourteenth centuries: in Artois, Namur, the bishopric of Liège, and in Brabant, particularly in the major urban drapery of Leuven. ${ }^{97}$ In Flanders, to be sure, the drie steden did not use fulling mills; but their town governments did operate and/or lease water-driven grain mills throughout the entire medieval era. ${ }^{98}$ There was no compelling technological reason why these mills could not have been adapted for fulling, as they were in the late-medieval English cloth towns, certainly if those towns had been both able and willing to invest in the much more complex but more powerful overshot wheels, with mill races.

Carus-Wilson also provided an ancillary, if seemingly redundant, reason for the Flemish failure to use

95 Van Uytven, "Fulling Mill,” pp. 1-14; see pp. and n. 119 below.

${ }^{96}$ See Carus-Wilson, "Woollen Industry" (1952 edn.), p. 413; but in the 2nd edition (CEH, 1987), p 674. she amended that to say that Flanders was "on the whole a land of windmills," in response to Raymond Van Uytven, "The Fulling Mill: Dynamic of the Revolution in Industrial Attitudes," Acta Historiae Neerlandicae, 5 (1971), pp. 1-14, which demonstrated the subsequent use of water-powered fulling mills in the southern Low Countries. Carus-Wilson, however, never explained why she believed that windmills were unsuitable for powering fulling-mills; perhaps, in her view, they failed to provide continous reciprocal power with the even motion of water-mills.

${ }_{97}$ Van Uytven, “Fulling Mill," pp. 1-14.

${ }^{98}$ Examples of water mills in: (a) Bruges: Stadsarchief Brugge, Stadsrekening 1291-92, passim: ad molendinum ad aquam; Stadsrekening 1351-52, fo. 70-2ro: ter Watermuelene ten Wijgaerde; (b) Ghent: Stadsarchief Ghent, Stadsrekening 1333-34, reeks n. 400:3(5), fo. 140ro: vanden neue watermolne ter Braembruggen boven den Temerkerke; (c) Ypres: Georges Des Marez and Etienne De Sagher, eds., Comptes de la ville d'Ypres de 1267 à 1329 (Brussels, 1909-13), I, p. 294, no. 21 (1309-10): des moulins a ewe; no. 36, pp. 426-27 (1324-25): des molins à yauwe à le porte de Messines; Algemeen Rijksarchief België, Rekenkamer, reg. n. 38,635: Stadsrekening, July - Sept. 1406, fo. 2ro.: receipts from the watermuelen ter Meesenpoorte, £35 10s 0d parisis. 
fulling-mills: prohibitions by the urban cloth guilds, 'which were not less conservative than those in England, and very much more powerful'. ${ }^{99}$ Powerful they certainly came to be after 1302 in the drie steden, but there were no such prohibitions, certainly none recorded in the often voluminous guild keuren of the drie steden and of the smaller towns. By far the most extensive set of fullers regulations to survive, largely for the second half of the fourteenth century, are those for Ypres, the weakest of the drie steden, the one most susceptible to rural competition from the nouvelles draperies, and especially those on the nearby Leie river, in a region much more suitable to undershot waterwheels than any other region in Flanders. Yet no reference to fulling mills can be found within the 114 articles of this Ypres fullers' keure; and provisions stipulating that four days' labour be devoted to fulling broadcloths and from two to three days' for 'small' [i.e. narrow] woollens clearly establish that foot-fulling was the only mode then to be considered. ${ }^{100}$

Even if mechanical fulling had been available, the fullers' guilds of the drie steden never enjoyed the unilateral power to prevent its use, even when they occasionally participated in urban coalition governments. In all the towns, the fullers, as the wage-earning employees of the weaver-drapers, the true industrial entrepreneurs, were almost always the weaker party, with a clearly defined subordinate status in the town governments of Bruges and Ypres. In Ghent, after many decades of often bitter strife, the defeated fullers were permanently evicted from the ranks of the town schepenen (aldermanic council), by or shortly after 1361; and henceforth town-appointed officials supervised their guild. ${ }^{101}$ In the drapery towns of neighbouring Brabant

${ }_{99}^{99}$ Carus-Wilson, “Woollen Industry,” p. 413 (1952 edn.); modified in 1987 edn., p. 674.

${ }^{100}$ Espinas-Pirenne, Recueil de documents, III, doc. no. 778, pp. 568-85.

101 Hans Van Werveke, "De economische en sociale gevolgen van de muntpolitiek der graven van Vlaanderen (1337-1433)," Annales de la Société d'Emulation de Bruges, 74 (1931), pp. 1-15; Hans Van Werveke, De koopman-ondernemer en de ondernemer in de Vlaamsche lakennijverheid van de middeleeuwen, Mededelingen van de Koninklijke Vlaamsche Academie voor Wetenschappen, Letteren en Schoone Kunsten van België, Klasse der Letteren, VIII: 4 (Antwerp, 1946), pp. 5 - 26; Hans Van Werveke, Gand: Esquisse d'histoire sociale (Brussels, 1946), pp. 48-69; V ictor F ris, "L es origines de la réforme constitutionelle de Gand de 1360-1369," Bulletin de la Société d'histoire et d'archéologie de Gand, 9 (1909), 427-59; David Nicholas, The Metamorphosis of a Medieval City: Ghent in the Age of the Arteveldes, 1302 - 1390 (Lincoln, 1987), pp. 135 - 77, 235-62; Nicholas, Medieval Flanders, pp. 242-6; Munro, "Industrial Entrepreneurship," pp. 377-88. See the next note. 
and Holland, the fullers had even less influence with urban governments strongly dominated by merchants and merchant-drapers; and in Leiden the mercantile gerecht brutally suppressed several fullers' strikes and rebellions during the fifteenth century. ${ }^{102}$

In all of this guild strife, in Flanders, Brabant, and Holland, the major issue was wages; and if the fullers' wages accounted for about 20 percent of the value-added manufacturing costs, the weaver-drapers had a very strong incentive not just to control wages but to reduce those labour costs. If, however, they did not seek to do so by installing fulling-mills, not even in the face of steadily rising costs and mounting competition from the English and Italian cloth-export trades, during the later fourteenth and fifteenth centuries, they had good reason to disdain mechanical fulling, in offering them any possible avenue of salvation. Having been forced to reorient textile manufacturing for export markets, and thus having so resolutely staked their fortunes on producing the very finest luxury-quality woollens, these urban draperies collectively feared that mechanical fulling would have very adverse consequences upon the international reputation of their woollens. For in this era, the belief was widespread that the incessant pounding of the heavy oaken hammers in fulling mills would degrade the very finest woollens, made from the most delicate, thin-fibred wools if not the medium grade woollens. Even if that view had been exaggerated, these draperies could have taken no chance that mechanical fulling would 'debase' the cloth-seals that were the veritable sine qua non of their success in international markets. $^{103}$

${ }^{102}$ K. Spading, "Streikkämpfe des Vorproletariats in der holländischen Tuchstadt Leiden im 15. Jahrhundert," Wissenschaftliche Zeitschrift der Ernst-Moritz-Arndt Universität Greifswald, Gesellschaftsund sprachwiss. Reihe, 18 (1969), pp. 171-75; Marc Boone and Hanno Brand, "Vollersproeren en collectieve actie in Gent en Leiden in de 14e en 15e eeuw," Tijdschrift voor sociale geschiedenis, 19:2 (May 1993), 16892; Marc Boone, Hanno Brand, and Walter Prevenier, "Revendications salariales et conjoncture économique: les salaires de foulons à Gand et à Leyde au XVe siècle," in Erik Aerts, Brigitte Henau, Paul Janssens, and Raymond Van Uytven, eds., Studia Historica Oeconomica: Liber Amicorum Herman Van der Wee (Leuven, 1993), pp. pp. 59-74; M. G. Willemsen, "La grève des foulons et des tisserands en 1524-1525 et le règlement général de la draperie malinoise de 1544," Bulletin du cercle archéologique de Malines, 20 (1910), 1-115.

${ }^{103}$ On contemporary views about the impact of mechanical fulling on quality, see Statutes of the Realm, II, pp. 474-4 (22 Edwarardi IV c. 15, 1482-83); Van Uytven, "Fulling Mills," pp. 1-14; and Van Uytven, "Productivity," p. 285, citing a text of 1403, contrasting the superiority of foot-fulled cloths from Lormaye (Nogent-le-Roi) with mill-fulled cloths from Chartres; Michel Mollat, "La draperie normande," in 
The Flemish drie steden in particular had all the more reason to be concerned about the international reputation of their woollens and consumer confidence in their cloth sales, because of the noxious competition from many of the domestic nouvelles draperies that evidently engaged in imitating, if not counterfeiting, the very fine woollens of the drie steden. Contary to much of the published literature on these industries, the socalled nouvelles draperies did not produce cheap and light textures, during the later fourteenth and fifteenth centuries. Previously, during the thirteenth and early fourteenth centuries, many of these villages draperies had in fact produced light says, tiretaines, doucken, and other cheap worsted-like fabrics; but from the 1330s those rural draperies that did survive followed the drie steden in re-orienting production more and more to luxuryquality woollens, as heavy as any of those from the drie steden; and some imitated not only the drie steden's woollens, in their dimensions and textures, but also in the selvages and seals, or so the latter claimed. ${ }^{104}$ The leading nouvelles draperies of this era -- Wervik, Kortijk, Menen, Comines, Linselles -- sold their good quality woollens for prices ranging from one-half to two-thirds those of the drie steden, but generally well above those for exported English woollens. Evidently they were able to do so by using lesser quality English wools, in lesser quantities, with simpler manufacturing techniques. Certainly, with the aid of Italian merchants who invested in their draperies, these particular nouvelles draperies proved to be very successful in capturing some Mediterranean markets at the direct expense of the drie steden. ${ }^{105}$

Marco Spallanzani, ed., Produzione, commercio e consumo dei panni di lana (nei secoli XII - XVIII), Atti della Seconda Settimana de Studio, 10-16 april 1970 (Florence: Leo S. Olschki, 1976), pp. 403-22; in particular with reference to the proposed fulling-millat Louviers: p. 418: "on l'accusait de ruiner le renom acquis par la production de Louviers sur la plan international..." In fifteenth-century Barcelona, fulling-mills were widely used in the production of cheaper woollens, but for the finest woollens, those made from English wools, foot-fulling was obligatory. Carrère, Barcelone, I, pp. 448-52. See also Carus-Wilson, "Woollen Industry" (1987 edn), p. 675; Swanson, Medieval Artisans, pp. 41-2. On cloth seals, see Walter Endrei and Geoffrey Egan, "The Sealing of Cloth in Europe, With Special Reference to the English Evidence," Textile History, 13 (Spring 1982), 47-76.

${ }^{104}$ See N. De Pauw, ed., Ypre jeghen Poperinghe angaende den verbonden: gegingstukken der XIVde eeuw nopens het laken (Ghent, 1899), pp. 1-180; Espinas and Pirenne, Recueil de documents, III, no. 649, pp. 168-222; Munro, "Industrial Transformations," pp. 114-17; Munro, "New Draperies," pp. 60-5.

${ }^{105}$ See Munro, "Industrial Transformations," pp. 114-20; Munro, “New Draperies,” pp. 64-83; Melis, "L’industrie drapière," pp. 151-61. 
There is no evidence, however, that even those nouvelles draperies situated on the faster-flowing portions of the Leie river in southern Flanders ever sought to reduce costs and thus prices by resorting to fulling-mills -- not in this era; and the voluminous fullers' keure of Wervik, reissued in 1397, differs in no significant respects from the previously discussed keure for Ypres, and it certainly has no references to fulling mills. ${ }^{106}$ Subsequently, however, during the sixteenth century, many of these Leie Valley draperies re-oriented production once more towards the production of cheaper fabrics, including semi-worsteds and bays, which did require some fulling; and in so doing, they readily adopted fulling-mills. So, during the course of this same century, did Leuven, Hasselt, and some other draperies in neighbouring Brabant, in manufacturing similarly cheaper fabrics. ${ }^{107}$ Thus the Leuven drapery resumed the use of mills that it had abandoned during the early fourteenth century, when, according to this town's leading historian, Raymond Van Uytven, it had 'switched over' to the production of luxury woollens production for export markets. ${ }^{108}$ The same had been true of many draperies in Normandy, where, during the later Middle Ages, only a few fulling mills were retained, principally for les gros draps bureaux, de grosses et mauvaises laynes. ${ }^{109}$

If the sixteenth-century draperies, in producing less quality woollens and serges, found that mechanical fulling was effective in reducing costs, would the same have been true for the fifteenth-century draperies in producing luxury woollens, if there had been no valid concerns about impairing their quality? To be sure, as

${ }_{106}$ De Sagher, ed., Recueil de documents, III, no. 554, pp. 452-78.

107 Van Uytven, “Fulling Mill,” pp. 1-14; De Sagher, ed., Recueil de documents, I-III, passim.

${ }^{108}$ Van Uytven, “Fulling Mill,” pp. 1-6; Van Uytven, “Technique, productivity,” pp. 283-94. For documents on the Leuven fulling mill in Sept. 1298, see Florent Prims, "De eertse eeuw van de lakenniiverheid te Antwerpen, 1226-1328," Antwerpsche archievenblad, 2nd ser. , 3 (1928), doc. no. 8, p. 148. For a fulling mill at Saint-Omer in 1280, see Espinas-Pirenne, Recueil de documents, III, no. 651, no. 243.

${ }^{109}$ Cited in Mollat, "Draperie normande," p. 418. The petites draperies of Artois (Hesdin, St. Pol, Aire) and the Meuse Valley region (Huy, Liège, Verviers, Maastricht) that continued to use fulling mills evidently also produced only cheap fabrics for local or regional consumption. See Espinas-Pirenne, Recueil de documents, I, no. 10, 28-32 (Aire, 1358); no. 13, pp. 36-37 (Aire, 1359); no. 15, pp. 38-39 (Aire, 1377); II, no. 582, p. 689-90 (Hesdin-le-Vieuw, 1340); no. 587, pp. 699-700 (Hesdin-le-Vieux, 1377); IV, pp. 69-70 (Hesdin-le-Vieux, 1379); III, no. 706, p. 336 (Saint-Pol, 1383); Georges Espinas, La draperie dans la Flandre française au moyen âge, 2 vols. (Paris, 1923), I, pp. 159-60; II, pp. 212-13, 742-46. 
demonstrated earlier, fulling-mills might have reduced the weaver-draper's value-added manufacturing costs or labour costs from about 20 percent with foot-fulling to about 5 percent with mechanical fulling. ${ }^{110}$ But that cost saving would not nessessarily have enhanced his profit margins by any significant degree, because that cost reduction would have permitted, at best, only a 3 per cent reduction in the wholesale prices of his broadcloths. ${ }^{11}$ The reason for such a very meagre price reduction is, of course, the fact that industrial labour accounted for only about 15 - 20 per cent of his total costs for a finished cloth, while the raw materials -- the fine English wools and the costly dyes -- accounted for the other 80- 85 per cent, and thus of the wholesale price. Indeed, the structure of English wool export taxes, as a fixed specific duty per woolsack, actually encouraged drapers in the Low Countries and Florence to buy the best and most expensive wools, for which this tax would thus represent a lower percentage of the wool price. Since the finer woollens of the Flemish drie steden and other drapery towns in the Low Countries were already about three times more expensive than rival English broadcloths (see Table 3), such a very minimal price reduction of 3 per cent would not have gained them many new customers; and any such gains would not have offset the loss of former customers who refused to buy mechanically-fulled luxury woollens, not when they still remained so high in price compared to English broadcloths. This point may be better understood by examining the economic principles that explain how the Low Countries' draperies priced their luxury woollens.

\section{Towns and the economics of monopolistic-competition in the Low Countries' draperies}

Such a luxury orientation in Flemish textile manufacturing certainly found its economic justification by the very survival of their luxury urban draperies for almost a century, from the 1340 s to the 1440s. But the economics of both supply and demand -- of wool costs and cloth markets -- forced the Flemish drie steden to

${ }^{110}$ See above, p. and $\mathrm{n}$.

${ }^{111}$ A potential 75 per cent cost-saving from mechanized fulling of two voirwollen halvelakenen at Leiden in 1435 and 1449 ( 75 per cent of 46d) represents only 3.23 per cent of their price, $£ 4$ 9s $0 \mathrm{~d}$ groot; and only 2.73 per cent of the $£ 7$ 0s 0d groot price for a Ghent dickedinnen in 1436. Fulling costs from Posthumus, Bronnen leidsche textielnijverheid, I, nos. 121, 124, pp. 136-39; Prices from Gemeente archief te Leiden, Diversche Rekeningen, no. 999; Archeif der secretarie van de Stad, no. 522, fo. 92-3; Stadsarchief Gent, Stadsrekening, Reeks 400:15, fo. 15ro. 
exercise their own comparative advantage in the upper-range luxury market, while necessarily relinquishing the lower ranges to rival woollens, especially the English and those of the nouvelles draperies. Obviously, a market for ultra-luxury woollens at double or triple the price or more of these rivals would ultimately become a very small one; ${ }^{112}$ and, if still a lucrative market for a select coterie of survivors, it was for the Flemish drie steden a fiercely competitive one, in quality more than in price. Their products, after all, had to compete with each other's textiles, and with other Flemish, Brabantine, Dutch, Norman, and Florentine luxury-quality woollens, let alone with the English.

Economists would call this monopolistic competition, in which the cloth producers had become 'pricemakers', rather than 'price-takers', each selling unique or distinctly different woollens, which had, however, close substitutes. For the late-medieval Low Countries, this form of monopolistic competition was also peculiar in that the competitive price-making unit was not the individual draper or family firm or partnership, but rather the urban drapery itself. ${ }^{113}$ Ideally, it would maximize profits (for each brand of cloth) when marginal costs equalled marginal revenue (i.e. by establishing both optimum output and price from the intersection of MR = MC). The marginal revenue itself was determined by the slope of the demand curve for that particular

${ }^{112}$ For comparative cloth prices, see Munro, "Industrial Protectionism," Tables 13.2-13.5, pp. 25667; John Munro, "The Medieval Scarlet and the Economics of Sartorial Splendour," in Negley B. Harte and Kenneth G. Ponting, eds., Cloth and Clothing in Medieval Europe: Essays in Memory of Professor E. M. Carus-Wilson, Pasold Studies in Textile History No. 2 (London, 1983), Tables 3.4-3.11, pp. 40-52, reprinted in John Munro, Textiles, Towns, and Trade; Munro, "Industrial Transformations," Appensix 4.1, pp. 143-8; Munro, "New Draperies," Tables 1-3, pp. 39-44. For the decline and scale of production, see statistical tables in Munro, Wool, Cloth and Gold: The Struggle for Bullion in Anglo-Burgundian Trade, c. 1340-1478 (Brussels, 1973), pp. 181-86; Munro, "Industrial Protectionism," pp. 229-67; Munro, "Industrial Change," pp. 110-60; John Munro, "Economic Depression and the Arts in the Fifteenth-Century Low Countries," Renaissance and Reformation, 19 (1983), pp. 235-50; reprinted in Munro, Textiles, Towns, and Trade; Nicholas, Metamorphosis, pp. 135-77; Raymond Van Uytven, "La draperie brabançonne et malinoise du XIIe au XVIIe siècles: grandeur éphemère et décadence," in Marco Spallanzani, ed., Produzione, commercio e consumo dei panni di lana (Florence, 1976), pp. 85-97.

${ }^{113}$ See John Munro, "Urban Regulation and Monopolistic Competition in the Textile Industries of the Late-Medieval Low Countries," in John H. Munro and Erik Aerts, eds., Textiles of the Low Countries in European Economic History (Leuven, 1990), pp. 41 - 52; reprinted in Munro, Textiles, Towns, and Trade. Similar arguments for seventeenth-Mediterranean trade in textiles can be found in Richard Rapp, "The Unmaking of the Mediterranean Trade Hegemony: International Trade Rivalry and the Commercial Revolution," Journal of Economic History, 25 (1975), pp. 513-25: in terms "national" textile products. 
woollen, in turn shaped by current consumer preferences for substitute woollens in that price range. Each drapery therefore implicitly strove to steepen that slope, to reduce the price-elasticity of demand, by diverting consumer demand away from rival woollens. That meant enhancing the quality of their own woollens, while distinguishing them from all others. Obviously, the Flemish draperies sought considerable assistance from town governments in achieving these goals. Not surprisingly one of the very steps taken by the drie steden, from at least 1359, was to prohibit any importation and sale of English woollens with Flanders, a ban rigorously and effectively enforced until the late 1490 s. ${ }^{114}$

For these Flemish draperies in particular, and for late-medieval commerce in luxury textiles, we must reconsider the role of towns themselves and guilds, and especially of guild and urban government industrial regulations. The crucial role that these urban institutions played in their century-long reprieve was in defining and enforcing the requisite quality controls for this international competition: to establish the highest production standards; to impose them uniformly on all members of the collective drapery; and to provide customers with a convincing guarantee of such quality controls in the form of lead seals that signified inspection by town officials at key stages of production. ${ }^{115}$ Not only guilds and urban government institutions but urban concentration itself was doubly necessary for effecting such quality controls in cloth production. In the first place, no matter how literate were the drapers, or efficient in record keeping they became, concentration of the work force permitted a much more effective co-ordination and monitoring of the very highly refined division of specialized labour required for luxury production. Secondly, that concentration clearly permitted a more effective and efficient inspection and enforcement of industrial regulations. In other words, Van Werveke was

${ }^{114}$ See John Munro, "Bruges and the Abortive Staple in English Cloth: An Incident in the Shift of Commerce from Bruges to Antwerp in the Late Fifteenth Century", Revue belge de philologie et d'histoire, 44 (1966), pp. 1137-59; reprinted in Munro, Textiles, Towns, and Trade Munro (1966); Munro, Wool, Cloth, and Gold, chapters 1-4; Munro, "Industrial Protectionism," pp. 229-68. The contentions of some Belgian historians that the Flemish ban was not enforced are, in my view, erroneous, and based on a misreading of the documents; cf. Wilfrid Brulez, "Engels laken in Vlaanderen in de 14de en 15de eeuw," Handelingen 'Socièté de'Emulation' te Brugge, 108 (1971), 5-28.

${ }^{115}$ See nn 101, 111 above. 
correct in his original thesis, but for the wrong reasons. ${ }^{116}$

Obviously monopolistic competition in luxury textiles had a long-standing tradition, and thus urban industrial regulations for such high-priced textiles can be found in thirteenth-century Flemish and Artesian towns, well before these industrial transformations, though of course the bulk of the cheap-textile production that focused on largely undifferentiated production had been left unregulated. Nevertheless, briefly, from c.1285 to c. 1310, the Franco-Flemish towns had subjected one important branch of the cheaper light drapery, the sayetteries (or its draperie-sayetterie branch) to at least some detailed regulation. That may have represented a valiant but ultimately hopeless attempt to upgrade the quality of these textiles, in the face of rising transaction costs, for the reasons just suggested. ${ }^{117}$ Then, from the 1330s, urban industrial regulation became far more complex, reflecting this more general shift to luxury cloth production: far more encompassing, detailed, and meticulous in dictating especially quality controls. ${ }^{118}$ Admittedly some Flemish drapery regulations were designed to protect employment and income, with contracting markets; but obviously also some limitations on entry (of labour and capital), along with stipulated production techniques, were requisite for enforcing quality standards. Although many of these industrial keuren -- in Flanders, Brabant, and Holland -prohibited the use of cards and spinning wheels in the preparation of warp yarns (though generally not the wefts), such bans were justifiable on the grounds that such techniques, before the introduction of the Saxony

${ }^{116}$ See above, pp.

${ }^{117}$ See the regulations in particular for the Bruges and Ypres' sayetteries and stanforts, for sayesdrappés especially, in Espinas-Pirenne, Recueil de documents, I, nos. 139-41, pp. 369-426; III, nos. 754-56, pp. 466-72 Sapori records the sales of a few of these sayes at Florence, by the Del Bene firm, at prices ranging from 8.4 to 18.4 florins (=£1.39 to $£ 3.07$ sterling, or 9s. to 19s. 6d. gros Flemish), for says of 40 - 48 ells. Though far cheaper than the luxury Flemish woollens ( 35 - 40 ells) also sold there, priced up to 65 florins (and up to 100 florins $=£ 15$ st., for scarlets), these Franco-Flemish says were, nevertheless, still expensive, in terms of an Oxford mason's daily wage, then about 4d. sterling. See Armando Sapori, Una compagnia di calimala ai primi del trecento, Biblioteca storica toscana, vol. VII (Florence, 1932).

${ }^{118}$ See Espinas-Pirenne, Recueil de documents, I - IV; Henri Joossen, ed., "Recueil de documents relatifs à l'histoire de l'industrie drapière à Malines, des origines à 1384," Bulletin de la Commission Royale d'Histoire, 99 (1935); Posthumus, Bronnnen leidsche textieilnijverheid, I. 
Flyer-Wheel, seriously impaired the durability and quality of luxury woollens. ${ }^{119}$

By the 1330s, of course, the cloth guilds were playing a very active role in the Flemish urban governments, which evidently facilitated the enactment, acceptance, and enforcement of industrial regulations.

Furthermore, during the fifteenth century, the Flemish nouvelles draperies also came to imitate the drie steden's industrial organization as well as their textiles. Certainly the leading draperies, those of Kortrijk, Comines, Menin, Wervik, and subsequently those of Armentières and Neuve-Église as well, lost whatever semirural character they had once enjoyed to become more fully urban in their stuctures, with the full panoply of industrial keuren, urban regulations, urban inspections, and cloth seals. ${ }^{120}$ Similarly complex drapery regulations can also be found in the late-medieval Brabantine and Dutch towns (also from the 1330s), where, as already noted, textile craft guilds did not exercise similar power. ${ }^{121}$ That difference may explain, as noted earlier, why the Flemish drie steden had succeeded in enforcing a permanent ban on the import of English woollens, while the drapery towns of Brabant and Holland-Zeeland failed to do, after one abortive attempt in 1428. ${ }^{122}$ That, of course, took place, just when a rapidly growing volume of English cloth imports via Antwerp

${ }^{119}$ See Munro, "Textile Technology," pp. 693-701; Patrick Chorley, "The Evolution of the Woollen, 1300-1700," in Negley B. Harte, ed., The New Draperies in the Low Countries and England, 1300 - 1800, Pasold Studies in Textile History no. 10 (Oxford and New York, 1997), pp. 7-34. See Munro, 'Textile Technology'; Chorley, 'The Woollen,'. From the 1460s the Brussels and Mechelen draperies did permit the use of cards and spinning wheel in the preparation of warp yarns [Stadsarchief Brussel, no. XVI, Het Witte Correctieboek; no, 1435] and possibly the reason was the introduction of the Saxony Wheel, which, in using the 'flyer' with a differential bobbin, permitted continuous drafting, twisting, and winding of the yarn; the discontinuous process with the traditional wheel had meant variations in the twist and thickness of the yarns, leading to breakage on the loom.

${ }^{120}$ Compare the various urban drapery regulations (keuren) in Espinas and Pirenne, Recueil de documents, I-IV; with those in De Sagher, ed., Recueil de documents, I, pp. 101-91, for Armentières; II, pp. 1-84, for Comines; II, pp. 85-244, for Dixmude; III, pp. 2-74, for Menin; pp. 93-228, for Neuve-Église; pp. 252-399, for Poperinge; and pp. 434-596, for Wervik. The first extant edition of Armentières drapery keuren dates from 1510; but it contains "ordonnances .... que l'en fait et use anchiennement en icelle ville;" and it had utilized cloth seals from at least 1413 .

${ }^{121}$ Joossen, "Recueil de documents;" Posthumus, Bronnnen leidsche textielnijverheid, I.

${ }^{122}$ Munro, Wool, Cloth, and Gold, pp. 65-126; Munro, "Industrial Protectionism,” pp. 234-53; see n. above. 
and Middelburg had become so important to both merchants and cloth-finishers in these two principalities. ${ }^{123}$ The final crisis for the urban draperies of the Low Countries: the Calais Bullion ordinances, 1429-73

In so concentrating upon luxury or quasi-luxury (imitation) woollen production, both the traditional urban draperies in the Low Countries and most of the bigger nouvelles draperies had purchased their survival by making their industry hostages to the English crown, which evidently believed that foreign demand for English wool still remained inelastic -- even if the demand for the Low Countries' fine woollens was not so elastic. ${ }^{124}$ From 1429 to the 1470 s, during the crucial dénouement of the Hundred Years' War, the crown sought to extort more bullion and ready cash from the wool trade by imposing the disastrous Calais Staple Partition and Bullion Ordinances. These laws placed the Staple's wool trade more firmly in the hands of a small monopolistic Stapler clique, sharply raised wool prices, and forbade traditional sales credit, requiring full payment in coin and bullion. Burgundian retaliation against the English cloth trade, then warfare and military expeditions against Calais all failed to remove these hated Staple regulations; then finally, in 1473, Edward IV had Parliament revoke these noxious ordinances as the price to be paid for the duke of Burgundy's financial assistance in regaining his throne (battles of Barnet and Tewkesbury). ${ }^{125}$

During the crucial thirty years of these ordinances -- years also of plagues, warfare, severe depressions, and especially another ruinous Flemish conflict with the Hanse (1451-7)-- the Flemish and Brabantine urban draperies suffered their most precipitous decline, and then virtual collapse before the real onslaught of the English cloth trade, whose expansion from the 1460s was compared in the Low Countries to an inundacioni

${ }^{123}$ See Van der Wee, Antwerp Market, II, pp. 41-56; and above, pp. and nn. ;

${ }^{124}$ See Munro, "Wool-Price Schedules," pp. 143-59; and above, pp. and n. , for comparisons of English and Spanish wools in the early to mid-fifteenth century.

125 See Munro, Wool, Cloth, and Gold, pp. 70-179; 3-6; Lloyd, English Wool Trade, pp. 257-87; Eileen Power, "The Wool Trade in the Fifteenth Century," in Eileen Power and M. M. Postan, eds., Studies in English Trade in the Fifteenth Century (London, 1933), pp. 39-90. Duke Charles the Rash had supplied Edward with fourteen ships and 50,000 gold florins to invade England and attack Warwick's forces in 1471. 
maris immensi. ${ }^{126}$ As table 2 indicates, the mean decennial production indices for the Ghent, Leuven, and Ypres draperies all fell about 70 per cent from 1420-9 to 1470-79. More concrete evidence can be found in the 83 per cent decline in the number of drapery stalls rented in the Ypres cloth hall over this period, from a mean of 397.7 to just 66.2 stalls. Equally tangible if less dramatic is the 42 per cent drop in mean wool exports to Calais over this same period, from 13,328 sacks to 7,762 sacks. ${ }^{127}$ Of the traditional, urban, English-wool based draperies, only Leiden weathered these storms, thanks to an aggressive Dutch merchant marine that was then invading and displacing the Hanse in the key Baltic markets, while taking advantage of several FlemishHanse conflicts to expand Dutch cloth sales there. ${ }^{128}$

In 1467 the Burgundian ambassadors had vainly warned the English that their badly damaged draperies in the Low Countries would soon 'be forced to give up cloth-making or else obtain wool from elsewhere'. ${ }^{129}$ That may have been an idle threat from the traditional urban draperies de luxe; but not for many

${ }^{126}$ Munro, Wool, Cloth, and Gold, pp. 155-85; Munro, "Industrial Protectionism," pp. 229-67; Munro, "Industrial Change," pp. 95-161; Munro, "Economic Depression," pp. 235-50; and, most recently, Pamela Nightingale, "England and the European Depression of the Mid-Fifteenth Century," The Journal of European Economic History, 26:3 (Winter 1997), 631-56.

127 The overall decline in total English wool exports from 1350-59 to 1470-79 was, however, 77 per cent. The Mechelen index fell by only 39 per cent over this period, because the Mechelen drapery did achieve some recovery from the 1460s, as the centre of the Burgundian court, and as a major entrepot and trading centre on the reviving overland continental routes between Italy and the Antwerp fairs, via South Germany and the Rhineland; and was able to participate in the growing cloth trade with South German metal merchants. See Munro, "Patterns of Trade," pp. 160-68; Wenceslaus Mertens, "Changes in the Production and Export of Mechelen Cloth, 1330 - 1530," in Erik Aerts and John Munro, eds, Textiles of the Low Countries in European Economic History (Leuven, 1990), pp. 114-23; Wencelaus Mertens, "Toenemende economische welvaart," in Raymond Van Uytven, ed., De geschiedenis van Mechelen: van heerlijkheid tot stadsgewest (Lannoo, 1991), pp. 83-93.

${ }^{128}$ See Malowist, "Expansion économique des Hollandais," pp. 91-138; T.S. Jansma, "Philippe la Bon et la guerre hollando-wende, 1438-1441," Revue du Nord, 42 (1960), 5-18; Hanno Brand, "Urban Policy or Personal Government: The Involvment of the Urban Elite in the Economy of Leiden at the End of the Middle Ages," in Herman Diederiks, Paul Hohenberg, and Michael Wagenaar, eds., Economic Policy in Europe Since the Late Middle Ages: The Visible Hand and the Fortune of Cities (Leicester and New York, 1992), pp. 1734. See also n. above.

${ }^{129}$ Rose-Marie Thielemans, Bourgogne et Angleterre: relations politiques et économiques entre les Pays-Bas bourguignons et l'Angleterre, 1435-1467 (Brussels, 1966), doc. no. 8, pp. 469-72; Munro, Wool, Cloth, and Gold, pp. 162-63. 
of the younger, more aggressive nouvelles draperies. In so far as they had been industrial 'counterfeiters', they were much more inclined to seek out other substitutes, which they were now finding in Spain's recently improved merino wools, even though they still remained quite inferior to the finest English wools (March, Cotswold, Lincolnshire), as noted earlier. ${ }^{130}$ For many years, several of the leading nouvelles draperies, such as those of Wervik, Kortrijk, Diksmuide, and Langhemarck, had all refused to make that substitution, contending that to do so would cost them customers; and Wervik had long required its drapers each year 'to swear a holy oath upon the cross to use none but English wools'. ${ }^{131}$ By the 1460s, however, most had adopted Spanish wools, though Wervik permitted them only for petits draps. ${ }^{132}$ Earlier, in the 1440 s, Brussels had established a Spanish-wool based nouvelle draperie, though also requiring it to be separate from the traditional drapery, which reinforced the traditional ban against adulterating its English Staple wools. ${ }^{133}$ The Flemish

${ }^{130}$ For Spanish wools, see above, pp. and n. . An English poem ("Libelle of Englysshe Polycye", ca. 1436) contended, undoubtedly with some justice, that: "The woole of Spayne hit cometh not to presse... Hit is lytelle valeue, trust unto me, wyth Englysshe wolle but if it menged [mixed] be:" in See George Warner, ed., The Libelle of Englysche Polycye (Oxfoerd, 1926), p. 6. The Armentières drapery keure of 1510 still required that the Spanish wools be mixed with one third Cotswolds, Lindsey (Lincs.) or Berkshire wools (per cloth). De Sagher, Recueil de documents, I, no. 36:2, p. 102.

${ }^{131}$ De Sagher, Recueil de documents, II, no. 242, pp. 85-97, 99-102 (Diksmuide); no. 377, pp. 62535, 649-50 (Langhemarck); III, no. 517, pp. 520-1; nos. 581-82, pp. 527-31; no. 586:195, p. 564 (Wervik, with the 1447 oath); Coornaert, Hondschoote, p. 191, n. 2 (Kortrijk). Munro, "Industrial Change," pp. 117-21; and "Economic Depression," pp. 235-50.

${ }^{132}$ Documents indicate that the following nouvelles draperies adopted Spanish wools during this era: Aalst, Armentières, Bailleul, Comines (Comen), Dendermonde, Dranoûter, Eecke, Eeklo, Flêtre, Geraardsbergen, Godeswaersvelde, Kemmel, Kortrijk, Menen, Meteren, Neuve-Eglise, Nieppe, Ninove, Oudenaarde, Poperinge, Tourcoing, Warneton, Wervik, Wulvergem. It is not clear that Langhemarck and Diksmuide ever did utilize Spanish wools (see n. 75). De Sagher, Recueil de documents, I, no. 102, p. 36; III, p. 2; no. 396, p. 37; no. 420, pp. 112-20; no. 275, pp. 304-05; no. 577, pp. 520-21; nos. 581-82, pp. 527-31; no. 586:195, p. 564; K. Höhlbaum, ed., Hansisches Urkundenbuch, Vol. X (Leipzig, 1939), no. 100, p. 639; Goswin von der Ropp, ed., Hanserecesse, 1431-1476, 2nd ser. 7 vols. (Leipzign, 1876-92), Vol. IV, no. 444:4, p. 312; L. Gilliodts-Van Severen, ed., "Les relations de la Hanse teutonique avec la ville de Bruges," Compte rendu des séances de la Commission Royale d'Histoire, 4th ser., VII (1879-80), no. 15, p. 216; no. 18, p. 233.

${ }^{133}$ For Brussels, see Favresse Favresse, "Note et documents sur l'apparition de la "nouvelle draperie" à Bruxelles, 1441-1443," Bulletin de la Commission Royale d'Histoire, 112 (1947), pp. 143-67; Felicien Favresse, "Les débuts de la nouvelle draperie bruxelloise, appelée aussi draperie légère," Revue belge de philologie et d'histoire, 28 (1950), pp. 59-74; Felicien Favresse, "La petite draperie bruxelloise, 1416-1466," Revue belge de philologie et d'histoire, 29 (1951), pp. 75-84. all reprinted in his Etudes sur les métiers 
urban draperies, however, evidently refused to establish such Spanish-wool based new draperies until far too late, on the seeming verge of extinction, in the sixteenth century: Ghent, evidently not before $1519 ;{ }^{134}$ and Bruges, not before $1544 .^{135}$

bruxellois au moyen âge (Brussels, 1961), pp. 59-74; (1950); Stadsarchief Brussel, no. XVI, and no. 1435 (for 1444 and 1467); Munro (1973), pp. 1-5. Leuven had authorized a new "small drapery" as early as 1415, using domestic and French wools; but this may not have been an export industry. Spanish wools cannot be documented at Leuven until the revisions of the keureboek (regulations) in 1481-1513. Stadsarchief Leuven, no. 1524; Van Uytven, Standsfinanciën, pp. 361-9.

${ }^{134}$ Stadsarchief Leuven no. 723, no. 1526, fo. 203-10 (for Ghent, 1519). Dr Marc Boone, however, has recently published undated documents on the Ghent drapery purporting that these indicate the establishment of a "new drapery" based on Spanish wools as early as the 1450s: Marc Boone, "Nieuwe teksten over de Gentse draperie: wolaanvoer, productiewijze en controlepraktijken (ca. 1456-1468)," Handelingen van de koninklijke commissie voor geschiedenis, 144 (1988), 1-61. While such an establishment is by no means impossible, and while Ghent merchants were then clearly engaged in the Spanish wool commerce (if only to service the nouvelles draperies), I cannot accept Dr Boone's arguments, and believe from internal evidence that the new drapery ordinances were enacted around 1519 (when they were copied by Leuven, as cited above). The text for the ordinance, which he dates to ca. 1453, is in a copy bound in a Cartularium prepared in 1545-8, 'ghetrocken uut der originale ordonnantien van der draperye': in Stadsarchief Gent, reeks 93, reg. KK, fo. 103'. Apart from the sixteenth-century spellings in this document (e.g. laecken instead of laken), the crucial test comes in the regulation of Hellemans, a new type of woollen that appears in registers of Ghent cloth purchases and sales only in 1496 (Stadsarchief Gent, Stadsrekeningen, Reeks 400: 32 (2), 1495-96, fo. 142 ro.) Furthermore, this same collection contains two other well dated Ghent drapery ordinances, for 1456 and 1462, "up dmaecken ende drapieren van den finen lakenene gheheeten dickedinnen ende andere lakenen die men drapiert ende maect binnen der stede van Ghendt," which -- in using fifteenth-century spellings -- make absolutely no mention of these new Spanish-wool based textiles, and require that all [sealed] woollens be made from English Staple wools: March and Middle-March [Shropshire and Herefordshire], Cotswolds [Worcestershire, Gloucester, and Oxfordshire], and Cotswolds-Berkshire wools. I have compared Boone's published version with those in the Ghent Stadsarchief, as noted above.

${ }^{135}$ Bruges, rather more surprisingly, continued to boast as late as 1533 that its 'principal industry' remained cloth-manufacture from English wools. Louis Gilliodts-Van Severen, ed. "Les relations de la Hanse teutonique avec la ville de Bruges au commencement du XVIe siècle," Compte rendu des séances de la Commission Royale d'Histoire, 4th ser., 7 (1879-80), no. 24, p. 272: "la draperie qui se fait des laines Dangleterre," in a letter concerning the Hanse, to the Dowager Queen of Hungary. Indeed, in that same year its magistrates explicitly reaffirmed the traditional ban on non-English wools. Rijksarchief West-Vlaanderen te Brugge Charters Blauwenummers, no. 8321: accusation of the deken of the wool-weavers guild, before the college of civic schepenen, on 17 Nov. 1533, against a dyer-draper who had made some woollens from Flemish and Rhenish wools, 'contrarie t'inhouden vanden drientseventich [73rd] article vanden keure vanden voors. ambochte dat expresselic verbiet and interdiceert eenighe Brugsche lakene te reedene dan van Inghelsche wulle, uuteghedaen smalle lakenen'. (A similar case was heard on 19 Jan. 1534 ns: RAWV Brugge, CB no. 8322.) That attitude may explain why an attempt to establish a nieuwe draperie with Spanish wools at this very time proved to be abortive. RAWV Brugge, CB no. 8320: petitions dated 12 Nov. 1533, concerning the "nieuwe draperie onlancx upghestelt ende beghonnen binnen der zelver stede van Spaensche wulle," to produce woollens in the style of Armentières for three years. See also Louis Gilliodts-Van Severen, ed., Cartulaire de l'ancien 


\section{Towns and industrial transformation in sixteenth-century textiles in the Low Countries and England}

Must we therefore conclude that urban guild-enforced regulation in Flanders, which had rescued the traditional draperies from destruction doom in the fourteenth century, now doomed most of them to extinction from the later fifteenth, by refusing to adjust to radically changed circumstances in both wool supplies and markets? The latter involved an economic recovery and expansion based, from the 1460s, on the Antwerp Fairs, propelled by the booming English cloth trade, the revival of transcontinental routes, and especially a renewed growth exports to the Mediterranean basin, where markets once more again favoured cheaper textiles. ${ }^{136}$ The evident beneficiaries were, first, the some of the newer nouvelles draperies, in particular Armentières and Neuve-Eglise (Nieuwkerke), which had adopted and become reliant on Spanish merino wools, whose sales volumes in the Low Countries certainly exceeded those of English wools by the the 1520s. ${ }^{137}$ Nevertheless, the governments and guilds of the Flemish drie steden were not misguided or wrong-headed in refusing to adopt Spanish merino wools; for many other nouvelles draperies that had resorted wholly or partially to Spanish merino wools failed to sustain their earlier growth and had also experienced severe decline

consulat d'Espagne à Bruges, 1rer partie: 1280 à 1550 (Bruges, 1901), I, pp. 296-7: Bruges succeeded in establishing a viable Spanish-wool-based drapery only after September 1544; and from June 1548 all woollens, 'new' and 'traditional', were made there exclusively from Spanish wools. The new drapery keuren (63 articles) of 20 Sept. 1544 are published in M. G. Willemsen, ed., "Le règlement sur la draperie brugeoise du 20 septembre 1544," Annales de l'Académie Royale d'Archéologie de Belgique, 69 (1921), 5-74: 'op te stellene een nieuwe draperie ende aldaer te drapierene ende reedene diveersche soorten van lakenen van Spaensche wulle [dobbel leeuwen, inkel leeuwen, ghecronde B, griffoen]'. In RAWV Brugge, CB nos. 8415-9, 8365, 8371-2 are other contemporary Bruges drapery ordinances (tempore Charles V) concerning 'eene nieuwe draperie' to produce 'diversche sorte van lakenen van Inghelsche ende Spaensche wulle' (CB no. 8414); and in others, ordinances for the production of lammekins and effen woollens: 'vander welke Spaensche wulle men sal moghen maken als hier ghemacet vander Yngelsche wulle' (CB no. 8419). On 7 July 1546, the Bruges schepenen ruled that, while the nieuwe draperie with Spanish wools would be regulated by the recent ordinances, the former keuren for the oude draperie with English wools were to remain in force (CB no. 8365). In June 1548 the drapers of the oude draperie stated that because of the great scarcity of English wools at Calais, and the imminent extinction of their drapery, they wished to secure the right to continue making their traditional woollens 'van Spaensche wulle' in the very same 'maniere als inhoudt ende verclaerst de keure vander ouder draperie vanden Inghelsche wulle' (in CB no. 8372).

${ }^{136}$ Van der Wee and Peeters, "Commerce mondiale," pp. 100-28; Van der Wee, Antwerp Market, II, pp. 73-142; Munro, "Patterns of Trade," pp. 165-81; Munro, "New Draperies," pp. 81-87.

137 See Phillips, Golden Fleece, pp. 40-2; Munro, "New Draperies," pp. 48-52. See the next note. 
in the later fifteenth century. ${ }^{138}$

Furthermore, the case of the Leiden drapery during the sixteenth-century is most instructive for comparative wool usages. As noted earlier, the Leiden drapery had been better able to sustain the growing onslaughts from the English cloth trades, evidently bouyed by the active and aggressive support from Dutch maritime merchants, who had gained increasing control over the Baltic markets, from the Hanse as well as the English, by the later fifteenth century. ${ }^{139}$ But by the early 1520 s, Leiden's cloth outputs had peaked; and in June 1522, after encountering further difficulties at the Calais Staple, the Leiden gerecht (magistrates) officially authorized the use of Spanish merino wools, which were now 25 per cent cheaper than the English. But even so, Leiden's drapers used merino wools only in limited quantities, usually mixed with some English wools. Soon complaints arose that Spanish merino wools were not only less fine than the English, but were more difficult to comb and required more time and effort in fulling and felting. Indeed, the contemporary English writer Clement Armstrong contended (c. 1535) that 'the wolles of Spayn are of such kynds [that] withowt the wolles of England be myxed with, it can no make no clothe of itself for no durable weryng, to be nother reisid nor dressid, by cause it hath no staple'; and indeed many of the leading nouvelles draperies, such as Armentières, used a mixture of two thirds Spanish and one third English wools. ${ }^{140}$ Subsequently, in 1536, after Leiden's experiment with merino wools had failed to stave off continued decline, its drapery decided once more to use English wools exclusively, despite their high cost, in order to their safeguard its reputation and thus

${ }^{138}$ See Peter Stabel, "Décadence ou survie? Économies urbaines et industries textiles dans les petite villes drapières de la Flandre orientale (14e-16e s.)," in Boone and Prevenier, La draperie ancienne des Pays Bas, pp. 63-84; Peter Stabel, Dwarfs among Giants: The Flemish Urban Network in the Late Middle Ages (Leuven-Apeldoorn: Garant, 1997).

${ }^{139}$ See above, pp. and nn.

140 “A Treatise Concerninge the Staple and the Commodities of this Realme," in R.H. Tawny and Eileen Power, eds., Tudor Economic Documents, 3 vols. (London, 1924), III, section ii.2, p.102; De Sagher, ed., Recueil de documents, I, no. 36, pp. 102-17 (Armentières drapery keure). 
maintain its now limited cloth markets, in confronting the relentless growth of English competition. ${ }^{141}$

The continuing importance of English wools for the Low Countries' draperies is well attested by the the royal customs accounts: in 1460-9, the decennial mean exports were 7,274 woolsacks; in 1510-9, mean exports were 7,634 woolsacks; and over this 50-year period, mean exports amounted to 7,978 woolsacks, sufficient to produce at least 34,571 broadcloths (of English measurement). ${ }^{142}$

The other major sector of the textile industries in the Low Countries that benefited from the changing structure of European markets and trade routes after the 1460s, were the now fully revived sayetteries, led by Hondschoote, which, as in the thirteenth century, produced cheap, light semi-worsted textiles, woven from coarse, long-stapled Flemish, Frisian, German (Pomeranian and Rhenish), and French wools. Indeed by the early to mid-sixteenth century they had surpassed the Spanish-wool based nouvelles draperies to become the leading manufacturers of textiles (certainly by volume and employment) in the southern Low Countries. ${ }^{143}$ Although Hondschoote had once been a village, it had become a full-fledged town by the early sixteenth-

${ }^{141}$ See Posthumus, Bronnen leidsche textielnijverheid, II, no. 903, pp. 316-17; Hanno Brand, "A Medieval Industry in Decline: The Leiden Drapery in the First Half of the Sixteenth Century," in Boone and Prevenier, La draperie ancienne des Pays Bas, pp. 121-49; J. A. Van Houtte, An Economic History of the Low Countries, 800 - 1800 (London, 1967), pp. 156-62.

${ }^{142}$ Carus-Wilson and Coleman, England's Export Trade, pp. 66-74.

${ }^{143}$ See Coornaert, Hondschoote, pp. 22-43, 236-53; and Coornaert, "Draperies urbaines," pp. 60-96; E. Maugis, "La saietterie à Amiens, 1480-1587," Vierteljahrschrift für Sozial-und Wirtschaftsgeschichte, 5 (1907), 1-115; Maurice Van Haeck, Histoire de la sayetterie à Lille, 2 vols. (Lille, 1910); Robert S. DuPlessis and Martha C. Howell, "Reconsidering the Early Modern Urban Economy: The Cases of Leiden and Lille," Past and Present, no. 94 (February 1982), pp. 49-84; Florence Edler, "Le commerce d'exportation des sayes d'Hondschoote vers Italie d'après la correspondance d'une firme anversoise, entre 1538 et 1544," Revue du Nord, 22 (1936), pp. 249-65; Donald C. Coleman, "An Innovation and its Diffusion: The 'New Draperies'," Economic History Review, 2nd ser. 12 (1969), pp. 417-29; Van der Wee, Antwerp Market, II, pp. 133-208, especially pp. 186-91; Hugo Soly and Alfons K. L. Thijs, "Nijverheid in de zuidelijke Nederlanden," in J.A. Van Houtte, et al., eds., Algemene geschiedenis der Nederlanden, VI (Haarlem, 1979), pp. 27-57; Alfons Thijs, "Les textiles au marché anversois au XVIe siècle," in Aerts and Munro, Textiles of the Low Countries (1990), pp. 76-86; Robert S. Duplessis, "One Theory, Two Draperies, Three Provinces, and a Multitude of Fabrics: the New Drapery of French Flanders, Hainaut, and the Tournaisis, c.1500 - c.1800," Negley B. Harte, ed., The New Draperies in the Low Countries and England, 1300 - 1800 (Oxford, 1997), pp. 129-72. 
century, with a fairly extensive and rigorous set of industrial regulations. ${ }^{144}$ Furthermore, all of the major towns in the Low Countries themselves established similar sayetteries or other draperies légères in the course of the sixteenth century; and this important industry had also become almost exclusively urban. ${ }^{145}$ Then, with the Revolt of the Netherlands against Spanish rule, which broke out in 1568 and lasted until the Truce of 1609, many Flemish artisans, and especially artisans from these sayetteries, fled from the Spanish armies that soon reconquered the south, and sought refuge in Holland, especially in Leiden, where they established the nieuwe draperie, to supplant the now declining woollen-based oude draperie; and even more settled in Norfolk and East Anglia, the former medieval homeland of English worsteds, where they also re-established this worsted and serge-based industry, which, as the so-called New Draperies of Tudor-Stuart England, also outstripped the traditional woollen-based Old Draperies by the 1640s. In both Holland and in England this say-based set of New Draperies was distinctly urban in organization and character, thus again leading us to question the supposed advantages of a rural location for early-modern textile industries producing for international markets. ${ }^{146}$

${ }^{144}$ Coornaert, Hondschoote, pp. 131-68; De Sagher, Recueil de documents, II, pp. 341-89.

${ }^{145}$ By the $1560 \mathrm{~s}$, sayetteries and related draperies sèches (serges, bayes, ostades, etc.) were operating in: Hondschoote, Bergues-St.-Winoc, Tournai, Lille, Amiens, Arras, St. Omer, Bruges, Ghent, Ypres, Mechelen, Leuven, Brussels, Leiden, Armentières, Neuve-Eglise, Bailleul, Béthune, Orchies, Dixmude, Poperinge, Menin, Halluin, Oudenburg, Lo, Douai, Valenciennes, Mons, Beauvais, Montreuil, Cambrai, SaintQuentin, Aubenton, Huy, Péronne, Reims, Abbeville. See Coornaert, Hondsdchoote, pp. 13-14, 81-82, 214-15; Van Haeck, Lille, I, pp. 46 et seq.; Maugis. "Amiens," pp. 1-110; Pirenne, "Crise industrielle," pp. 621-43; De Sagher, Recueil, I, pp. 192-8, 225; II, pp. 223, 562, 663-66; III, pp. 194-97; Duplessis, "New Drapery,” pp. 129-72.

${ }^{146}$ See Nicolaas W. Posthumus, Geschiedenis van de Leidsche lakenindustrie, 3 vols. (The Hague, 1908-1939); and in in Negley Harte, ed., The New Draperies in the Low Countries and England. 1300 - 1800 (Oxford, 1997), see the following: Leo Noordegraaf, "The New Draperies in the Northern Netherlands, 1500 1800," pp. 173-196; Martha C. Howell, "Woman's Work in the New and Light Draperies of the Low Countries," pp. 197-216; B. A. Holderness, "The Reception and Distribution of the New Draperies in England," pp. 217-44; Luc Martin, "The Rise of the New Draperies in Norwich, 1550 - 1622," pp. 24574;Ursula Priestley, "Norwich Stuffs, 1600 - 1700," pp. 275-88. 
Table 1. Exports of English Woolsacks and Broadcloths, Sales of Drapery Tax Farms at Ghent, Ieper (Ypres), and Mechelen; and Numbers of Drapery Stalls Leased in the Ieper Lakenhalle, in Quinquennial Means, 1335-39 to 1545-49

\begin{tabular}{|c|c|c|c|c|c|c|c|}
\hline Years & English & English & Ghent & Ypres & Ypres & Mechelen & Leuven \\
\hline [5 Yrs] & Wool & Cloth & Drapery Tax & Drapery Tax & Drapery & Drapery Tax & Drapery Tax \\
\hline & Exports & Exports in & Farm Sales & Farm Sales & Stalls & Farm Sales & Farm Sales \\
\hline & in Sacks & Broadcloths & in shillings & in shillings & Number & in shillings & in Rijnsgulden \\
\hline & [364 lb.] & {$[24 \times 1.75 y d]$} & groot Flem. & groot Flem. & Rented & groot Flem. & [number] \\
\hline & & & & & & & \\
\hline 1335-39 & 22,850 & & $2,286.60$ & & & & \\
\hline $1340-44$ & 19,732 & & $2,417.40$ & & & & \\
\hline 1345-49 & 24,968 & 3,196 & $2,141.80$ & & & & \\
\hline $1350-54$ & 30,204 & 1,621 & $2,249.60$ & & & & \\
\hline 1355-59 & 32,544 & 7,231 & $2,213.20$ & & & & \\
\hline $1360-64$ & 30,183 & 11,035 & $1,999.00$ & & & & \\
\hline 1365-69 & 29,603 & 14,684 & $1,355.60$ & & & & \\
\hline $1370-74$ & 24,081 & 12,723 & 987.20 & & & & \\
\hline 1375-79 & 21,659 & 13,154 & 772.80 & & & & \\
\hline $1380-84$ & 18,612 & 18,978 & 476.80 & & & & \\
\hline $1385-89$ & 17,412 & 25,351 & 385.18 & & & & \\
\hline $1390-94$ & 19,543 & 36,842 & 293.55 & & & & \\
\hline 1395-99 & 17,546 & 40,096 & 201.93 & & & & \\
\hline $1400-04$ & 12,552 & 37,810 & 110.30 & & & $6,194.00$ & 2,385 \\
\hline 1405-09 & 12,997 & 29,216 & 146.10 & $5,458.00$ & 430.00 & $5,918.00$ & 2,990 \\
\hline $1410-14$ & 12,684 & 27,522 & 137.50 & $5,354.00$ & 419.00 & $6,204.00$ & 2,518 \\
\hline 1415-19 & 13,515 & 28,855 & 177.80 & $5,394.00$ & 510.70 & $5,930.00$ & 1,588 \\
\hline $1420-24$ & 13,401 & 36,449 & 156.90 & $5,322.00$ & 433.20 & $7,656.00$ & 1,126 \\
\hline 1425-29 & 13,255 & 41,446 & 195.10 & $5,106.00$ & 376.60 & $7,918.00$ & 757 \\
\hline $1430-34$ & 7,508 & 40,861 & 153.10 & $4,724.00$ & 330.50 & $6,100.00$ & 570 \\
\hline 1435-39 & 3,236 & 42,904 & 88.70 & $3,456.00$ & 217.20 & $3,524.00$ & 541 \\
\hline $1440-44$ & 9,759 & 57,056 & 82.60 & $3,486.00$ & 187.20 & $4,422.00$ & 417 \\
\hline
\end{tabular}




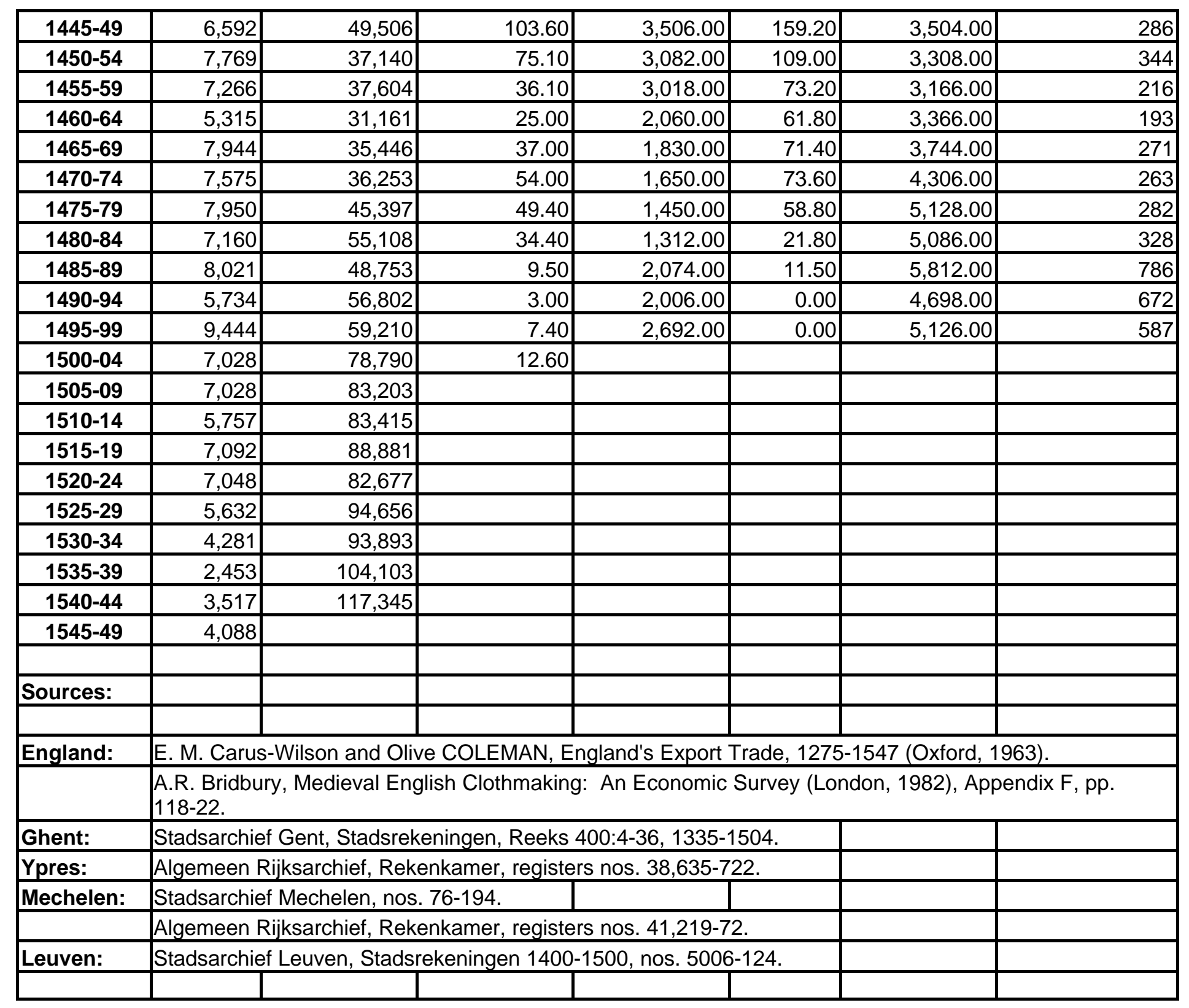


Table 2. Fifteenth-Century Prices of English Wools, English Broadcloths, and of Flemish Woollens in Pounds Sterling and Pounds Groot Flemish, and the Composite Price Indices for England and Flanders, in Quinquinquennial Means, 1400-04 to 1495-99

\begin{tabular}{|c|c|c|c|c|c|c|c|c|}
\hline Years & English Wool & English Cloth & Phelps-Brown & Flemish & Ghent Cloth & Ghent Cloth & Kortrijk & Other Nouvelles \\
\hline & Prices per sack & Export Prices & Price Index & Price Index & Prices in $£$ & Prices in $£$ & Cloth Prices & Draperies Cloth \\
\hline & in $£$ sterling & in $£$ sterling & $1450-74=100$ & $1450-74=100$ & groot Flem: & sterling: & in $£$ groot & Prices in $£$ \\
\hline & [domestic] & Mean Values & & & Dickedinnen & Dickedinnen & Flemish & groot Flemish \\
\hline 1400-04 & 5.572 & 1.666 & 114.3 & 88.3 & 5.919 & 5.647 & 3.238 & 3.118 \\
\hline 1405-09 & 6.057 & 2.000 & 103.6 & 98.7 & 5.922 & 5.650 & 3.421 & 3.263 \\
\hline 1410-14 & 6.236 & 2.000 & 109.5 & 95.0 & 5.793 & 7.206 & 3.435 & 2.881 \\
\hline 1415-19 & 4.652 & 2.000 & 113.9 & 108.1 & 5.935 & 6.872 & 3.424 & 2.646 \\
\hline 1420-24 & 5.136 & 2.402 & 99.3 & 106.3 & 6.082 & 5.833 & 3.550 & 2.637 \\
\hline 1425-29 & 4.859 & 2.001 & 105.4 & 117.1 & 6.063 & 5.675 & 3.917 & 2.700 \\
\hline 1430-34 & 5.546 & 2.464 & 113.6 & 128.3 & 6.835 & 5.874 & 4.187 & 3.675 \\
\hline 1435-39 & 5.550 & 2.729 & 113.5 & 137.7 & 7.281 & 6.597 & 3.750 & 3.750 \\
\hline 1440-44 & 5.204 & 2.295 & 102.0 & 120.6 & 7.765 & 7.035 & 4.285 & 3.778 \\
\hline $1445-49$ & 5.610 & 2.731 & 96.7 & 107.8 & 7.925 & 7.180 & 4.038 & 3.380 \\
\hline 1450-54 & 4.514 & 2.037 & 100.6 & 101.3 & 6.950 & 6.297 & 4.000 & 3.594 \\
\hline 1455-59 & 4.132 & 2.062 & 95.1 & 113.9 & 7.702 & 6.978 & & 3.306 \\
\hline $1460-64$ & 4.394 & 2.215 & 99.2 & 93.9 & 8.000 & 7.248 & & 3.075 \\
\hline $1465-69$ & 5.906 & 1.866 & 106.2 & 95.0 & 8.100 & 8.388 & & 3.125 \\
\hline 1470-74 & 5.285 & 2.096 & 98.8 & 96.0 & 8.642 & 8.340 & & \\
\hline 1475-79 & 6.143 & 2.382 & 87.2 & 111.8 & 8.875 & 7.535 & & \\
\hline 1480-84 & 7.779 & 2.723 & 128.9 & 157.2 & 10.348 & 7.272 & & \\
\hline 1485-89 & 8.671 & 2.905 & 100.0 & 164.0 & 14.893 & 7.366 & & \\
\hline $1490-94$ & 5.742 & 2.494 & 105.4 & 181.9 & 16.233 & 11.422 & & \\
\hline 1495-99 & 5.308 & 2.802 & 94.5 & 102.4 & 14.667 & 9.833 & & \\
\hline
\end{tabular}




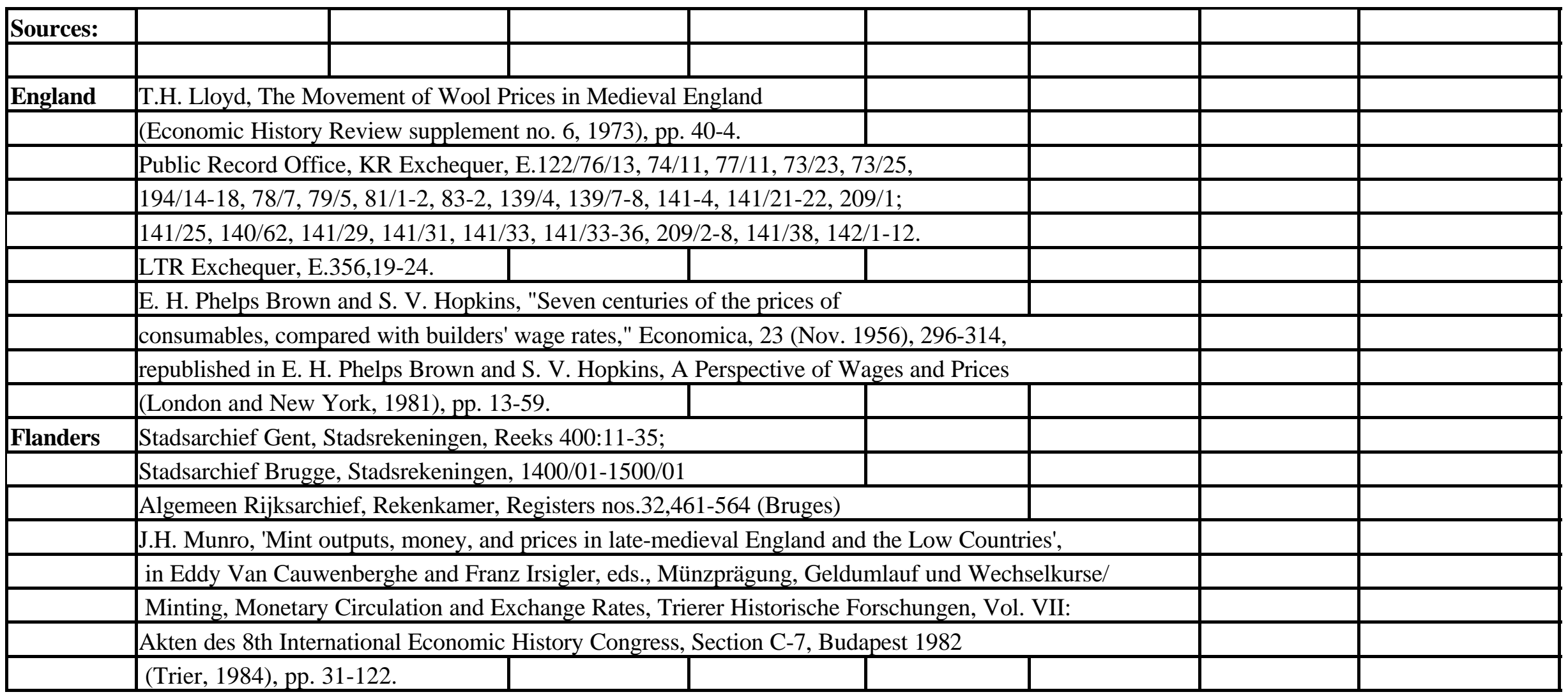


